\title{
DINÂMICA TEMPORAL E ESPACIAL DA MANCHA PRETA (Guignardia citricarpa) E QUANTIFICAÇÃO DOS DANOS CAUSADOS À CULTURA DOS CITROS
}

\author{
MARCEL BELLATO SPÓSITO
}

\begin{abstract}
Tese apresentada à Escola Superior de Agricultura
“Luiz de Queiroz", Universidade de São Paulo, para obtenção do título de Doutor em Agronomia, Área de Concentração: Fitopatologia
\end{abstract}

PIRACICABA

Estado de São Paulo - Brasil

Dezembro - 2003 


\title{
DINÂMICA TEMPORAL E ESPACIAL DA MANCHA PRETA (Guignardia citricarpa) E QUANTIFICAÇÃO DOS DANOS CAUSADOS À CULTURA DOS CITROS
}

\section{MARCEL BELLATO SPÓSITO}

Engenheiro Agrônomo

Orientadora: Profa. Dra. LILIAN AMORIM

\begin{abstract}
Tese apresentada à Escola Superior de Agricultura
"Luiz de Queiroz", Universidade de São Paulo, para obtenção do título de Doutor em Agronomia, Área de Concentração: Fitopatologia
\end{abstract}

PIRACICABA

Estado de São Paulo - Brasil

Dezembro - 2003 
Dados Internacionais de Catalogação na Publicação (CIP) DIVISÃO DE BIBLIOTECA E DOCUMENTAÇÃO - ESALQ/ USP

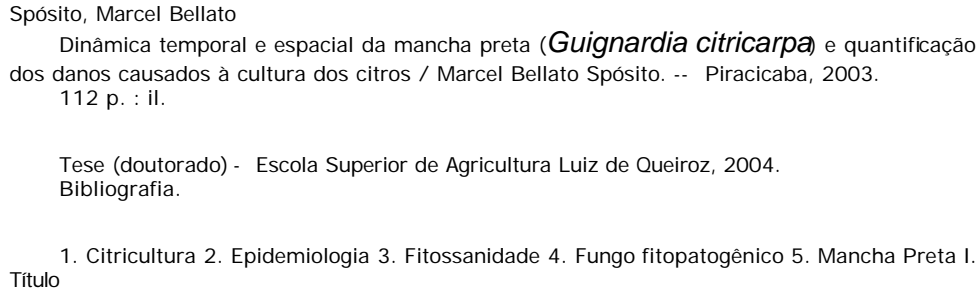

CDD 634.3

\section{"Permitida a cópia total ou parcial deste documento, desde que citada a fonte - $\mathrm{O}$ autor"}


Aos meus pais Pedro e Ana,

por todo amor, ensinamentos e oportunidades...

Ao meu irmão Kleber,

meu melhor amigo...

Aos meus tios Rolando, Adriano, Dorothy e Luiza pela presença constante em todos os momentos da minha vida...

... OFEREÇO

DEDICO ...

... a minha querida esposa Lygia,

por todo amor que existe entre nós. 


\section{AGRADECIMENTOS}

À Profa. Dra. Lilian Amorim, pela orientação, amizade e extrema dedicação em todas as etapas do meu doutorado.

Ao Prof. Dr. Armando Bergamin Filho, pelo conhecimento transmitido, pelas idéias, sugestões e colaboração nesta tese.

Ao curso de pós-graduação do Departamento de Entomologia, Fitopatologia e Zoologia Agrícola da ESALQ/USP, em especial a todos os professores pelos ensinamentos transmitidos e pela convivência aprazível durante todo o período.

Ao Dr. Eduardo Feichtenberger (APTA-Regional), pela transmissão de conhecimento, pelas sugestões e colaboração nesta tese e principalmente pela amizade.

Ao Dr. Renato B. Bassanezi pela amizade e por ter me auxiliado ao longo da tese, assim como aos demais amigos de trabalho Dr. Pedro T. Yamamoto, M. Sc. José Belasque Júnior, M. Sc. Antonio Coutinho e Célia T. Costa pelas trocas de informações diárias, que enriquecem nosso conhecimento.

Aos professores Dr. Paulo Justiniano Ribeiro e M.Sc. Glaucy C. Ortiz (UFPR), por me auxiliarem a desvendar os segredos da análise estatística espacial.

À Fundação de Amparo à Pesquisa do Estado de São Paulo (FAPESP) pelo recurso financeiro disponibilizado para o desenvolvimento desta tese.

Ao Conselho Nacional de Desenvolvimento Científico (CNPq), pela concessão de bolsa de estudo. 


\section{SUMÁRIO}

RESUMO_............................................................................ viii

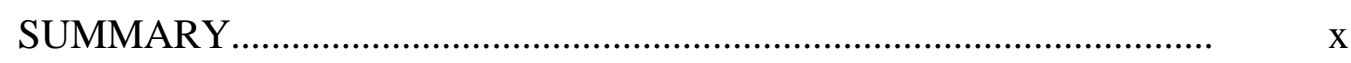

1 INTRODUÇÃO................................................................................. 1

2 REVISÃO DE LITERATURA.......................................................... 3

2.1 A mancha preta dos citros................................................................ 3

2.1.1 Distribuição geográfica e sintomatologia........................................... 3

2.1.2 Ciclo da doença.......................................................................... 5

2.1.3 Epidemiologia da doença.................................................................. 7

2.1.4 Controle e danos ocasionados pela doença......................................... 8

2.2 Ferramentas de análise de epidemias.................................................... $\quad 10$

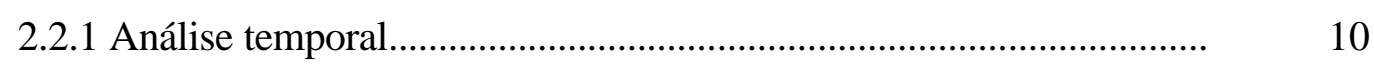

2.2.2 Análise espacial............................................................................. 12

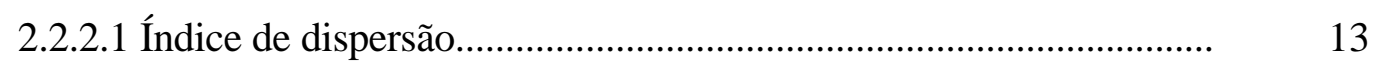

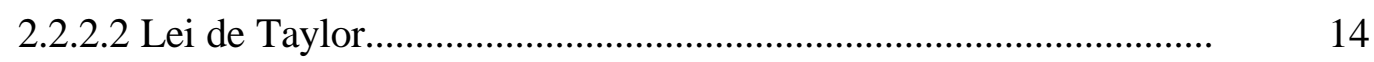

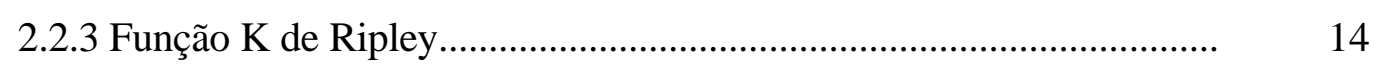

3 ELABORAÇÃO E VALIDAÇÃO DE ESCALA DIAGRAMÁTICA PARA AVALIAÇÃO DA SEVERIDADE DA MANCHA PRETA DOS CITROS 17

Resumo........................................................................................... 17

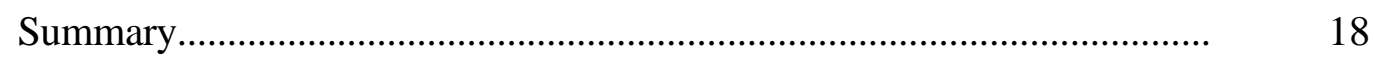

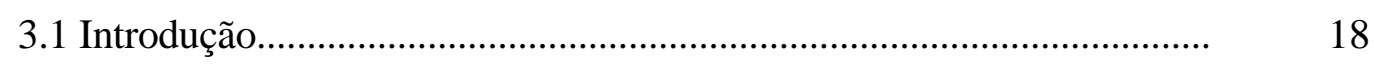

3.2 Material e Métodos......................................................................... 21 


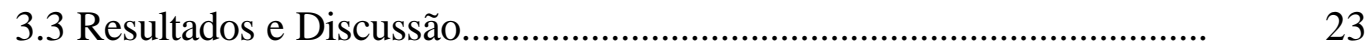

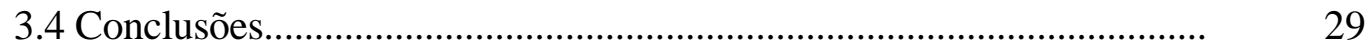

4 RESISTÊNCIA À MANCHA PRETA DOS CITROS AVALIADA POR CURVAS DE PROGRESSO DA DOENÇA........................................... 30

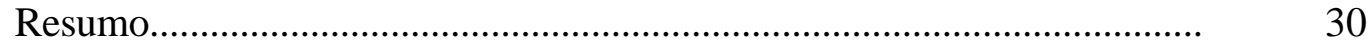

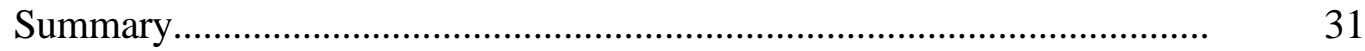

4.1 Introdução.......................................................................................... 31

4.2 Material e Métodos............................................................................... 33

4.3 Resultados e Discussão.................................................................... 34

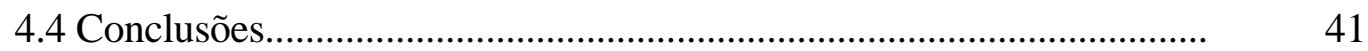

5 PADRÃO ESPACIAL DE LARANJEIRAS COM MANCHA PRETA DOS

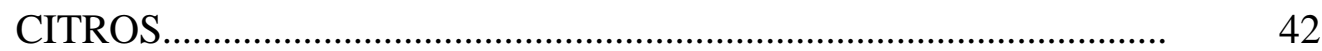

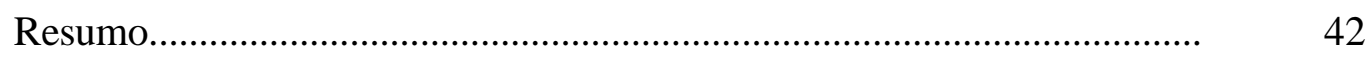

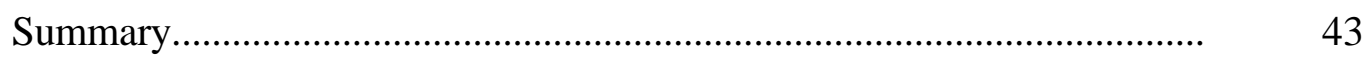

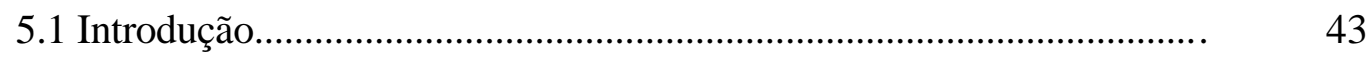

5.2 Material e Métodos.......................................................................... 44

5.3 Resultados e Discussão............................................................................. 47

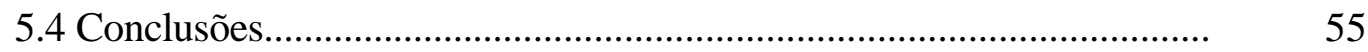

6 PADRÃO ESPACIAL DA INCIDÊNCIA DE FRUTOS SINTOMÁTICOS DE MANCHA PRETA EM PLANTAS CÍTRICAS RELACIONADOS À SEVERIDADE DA DOENÇA E DISPERSÃO DO PATÓGENO......... 56

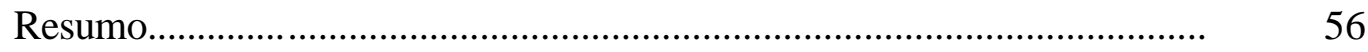

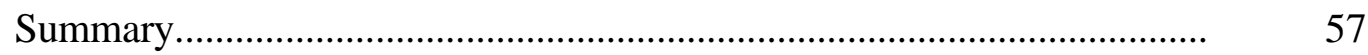

6.1 Introdução ......................................................................................... 58

6.2 Material e Métodos............................................................................ 60

6.2.1 Relação incidência-severidade.............................................................. 60

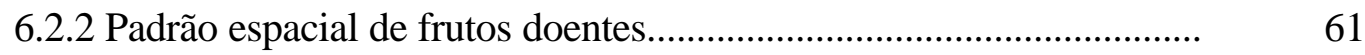

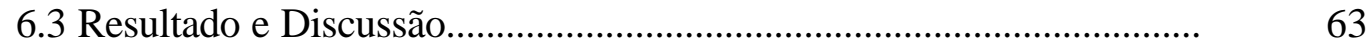

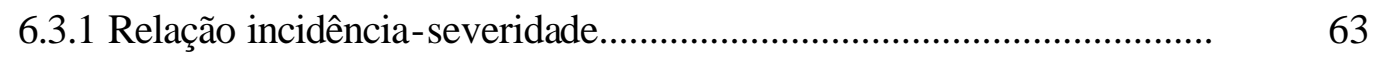

6.3.2 Padrão espacial de frutos doentes......................................................... 65 
6.4 Conclusões

7 IMPORTÂNCIA RELATIVA DAS FONTES DE INÓCULO DE Guignardia citricarpa NA EPIDEMIOLOGIA DA MANCHA PRETA DOS CITROS 74

Resumo 74

Summary. 75

7.1 Introdução 75

7.2 Material e Métodos... 77

7.3 Resultados e Discussão. 80

7.4 Conclusões 82

8 AVALIAÇÃO DE DANOS E PERDAS CAUSADOS PELA MANCHA

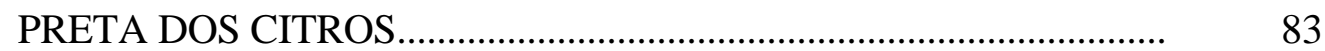

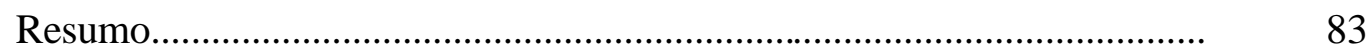

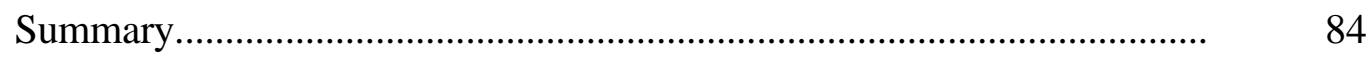

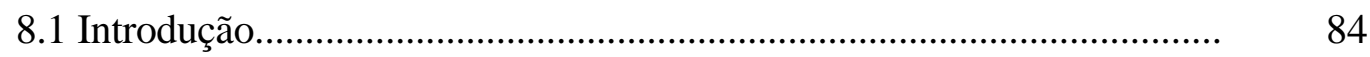

8.2 Material e Métodos............................................................................ 85

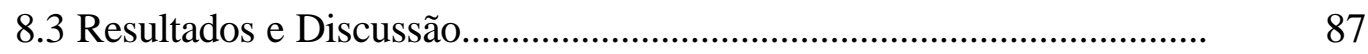

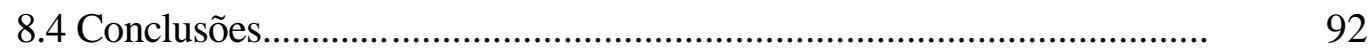

9 CONCLUSÕES GERAIS................................................................... 93

REFERÊNCIAS BIBLIOGRÁFICAS..................................................... 95

APÊNDICES......................................................................... 110 


\title{
DINÂMICA TEMPORAL E ESPACIAL DA MANCHA PRETA (Guignardia citricarpa) E QUANTIFICAÇÃO DOS DANOS CAUSADOS À CULTURA DOS CITROS
}

\author{
Autor: MARCEL BELLATO SPÓSITO
}

Orientadora: Profa. Dra. LILIAN AMORIM

\section{RESUMO}

A mancha preta dos citros (MPC), incitada pelo fungo Guignardia citricarpa, causa lesões em frutos depreciando-os para a comercialização no mercado interno de fruta fresca, restringindo-os para a exportação e pode causar queda prematura. Para auxiliar nos estudos epidemiológicos, foi desenvolvida uma escala diagramática para a severidade da MPC que contempla os dois tipos de sintomas usualmente observados no campo, "mancha dura", cujos valores variam entre 0,5 e 49,0\%, e "falsa melanose", cujos valores variam entre 1,1 e $68 \%$. O grau de suscetibilidade das variedades cítricas 'Hamlin', 'Pera' e 'Valência' à MPC foi avaliado em pomar comercial, sob infecção natural. $\mathrm{O}$ modelo monomolecular ajustoutse às curvas de progresso da incidência e da severidade da doença para as três variedades. Não houve diferença estatística 
significativa entre as taxas de progresso da MPC, concluindo-se que as três variedades possuem o mesmo grau de suscetibilidade à doença. O agente causal da MPC em sua fase epidêmica forma ascósporos e conídios. Os ascósporos, formados em folhas em decomposição no solo, são disseminados a curtas e longas distâncias pela ação do vento. Os conídios, formados em ramos e frutos fixados à planta, são disseminados a curtas distâncias pela ação da água. O padrão de distribuição espacial de plantas com MPC foi avaliado pelo índice de dispersão e pela função $\mathrm{K}$ de Ripley. As plantas doentes mostraram-se agregadas independentemente da incidência da doença, indicando elevada importância da dispersão do inóculo a curtas distâncias. Avalioutse, também, o padrão de distribuição de frutos sintomáticos dentro da planta, pelo índice de dispersão e pela forma binária da lei de Taylor. Pelo índice de dispersão $84 \%$ das plantas avaliadas mostraram agregação de frutos sintomáticos. Pela lei de Taylor concluiutse que a agregação de frutos sintomáticos independe da incidência da doença na planta, sugerindo a participação dos conídios no incremento da doença em condições de campo. Estudourse o efeito da supressão de ascósporos, pela retirada periódica de folhas cítricas em decomposição do campo e o de conídios, pela colheita antecipada de frutos de maturação tardia, na intensidade da MPC, por dois anos, em área com alta pressão de inóculo. Esses tratamentos reduziram a severidade da doença, no segundo ano de avaliação, entretanto não foram suficientes para controlá-la adequadamente. Estas medidas de sanitização são importantes no controle da MPC, devendo ser adotadas em conjunto com o controle químico. Danos causados pela redução na produtividade e perdas medidas pelo retorno financeiro foram avaliados em dois experimentos. Tratamentos cujo incremento na produção por hectare que, em comparação com a isenção de tratamento, excederam 100 caixas de 40,8 kg, foram rentáveis. A amostragem de áreas para diagnosticar a presença da MPC depende da finalidade da produção. Em áreas para exportação e mercado interno de fruta fresca deve-se avaliar todas as plantas do talhão, uma vez que esta doença é quarentenária e causa danos qualitativos. Em áreas para a indústria de suco cítrico concentrado, 285 plantas são suficientes para amostrar incidências superiores a 15\% de MPC, em pomares médios de 2200 plantas. 


\section{TEMPORAL AND SPATIAL DYNAMICS OF CITRUS BLACK SPOT (Guignardia citricarpa) AND QUANTIFICATION OF THE DAMAGES CAUSED TO CITRUS CULTURE}

Author: MARCEL BELLATO SPÓSITO

Adviser: Profa. Dra. LILIAN AMORIM

\section{Summary}

The fungus Guignardia citricarpa is the causal agent of citrus black spot (CBS), which is a disease that become the fruits unsightly and unsuitable for the fresh fruit market. Besides, premature fruit drop may occur, reducing the productivity. A diagrammatic scale for the two symptoms of CBS (hard spot and false melanose) was developed to evaluate the severity and help in epidemiological studies of this disease. The susceptibility level of 'Hamlin', 'Pera' and 'Valência' sweet orange to CBS was evaluated in commercial orchard, under natural infection. The monomolecular model was fitted to the incidence and severity progress curves of the disease for the three sweet oranges. According to the progress curves, there was not significant difference among cultivars, showing that 'Hamlin', 'Pera' and 'Valência' sweet orange have similar 
susceptibility level to CBS. G. citricarpa in the epidemic phase produce ascospores and conidia. The ascospores, produced in leaves on soil, are disseminated by wind, while conidia, produced in plant twigs and fruits, are disseminated by water. The pattern of spatial distribution of CBS plants was evaluated by dispersion index and Ripley $\mathrm{K}$ function. The groups of symptomatic plants were distributed independently of disease incidence, suggesting that short distance dispersion of the inocullum could be the most important factor in distribution of the disease. The binary form of Taylor's power law and dispersion index were used to evaluate the distribution of symptomatic fruits in the plant. According to dispersion index $84 \%$ of the evaluated plants showed aggregation of symptomatic fruits, while by the Taylor's power law the symptomatic fruits aggregation occurred independently of the incidence of plant disease, suggesting that the increase of disease in field conditions is related to conidia production. The effect of ascospore suppression on intensity of CBS was evaluated by removing citrus leaves from the orchard soil surface, while the conidia suppression was evaluated by early harvesting of late maturation fruits. These treatments, carried out during two years in a high inocullum incidence area, reduced the disease severity in the second year, but the satisfactory control was not observed. However, these treatments could be important in CBS control whether used in association with chemical control. Damages caused by yield reduction and losses of financial return were evaluated in two experiments. In relation to nontreated orchards, those treated orchards where the production/ha increased more than hundred boxes ( $40.8 \mathrm{~kg}$ each box) were considered profitable. The destination of the orange production (juice of fresh fruit market) are important for determine the size of samples to assess the CBS incidence. Since the G. citricarpa fungus is considered a quarentine organism that causes qualitative losses, in areas used for production of fresh fruit market whole orchard has to be evaluated. However, in areas used for production of fruits to concentrated orange juice, 285 plants sampled are enough to determinate the CBS incidence superior to $15 \%$, in average orchards containing 2200 plants. 


\section{INTRODUÇÃO}

O Brasil possui uma área plantada com a cultura dos citros de aproximadamente 615 mil hectares. No Estado de São Paulo, este agronegócio é responsável por cerca de 400 mil empregos diretos e indiretos, gerando receitas superiores a 2 bilhões de dólares por ano. Entretanto, toda esta estrutura leva a problemas fitossanitários. A continuidade espacial das propriedades nas regiões citrícolas, a continuidade temporal de órgãos suscetíveis, por serem plantas perenes sempre verdes, e a baixa variabilidade genética encontrada nos pomares cítricos, tanto em relação à copa quanto ao porta-enxerto, são condições que favorecem a ocorrência de pragas e doenças. Entre as doenças, a mancha preta dos citros (MPC), causada pelo fungo Guignardia citricarpa, atualmente, vem causando um grande impacto econômico à citricultura, pela redução da produtividade em pomares, depreciação dos frutos para o mercado de fruta fresca, além de onerar os custos de produção pelas diferentes estratégias de controle. Outro problema da MPC é que esta doença é considerada quarentenária A1 pela União Européia, o que vem ocasionando restrições nas exportações de frutos cítricos brasileiros para estes países. A MPC está presente no Brasil, na África do Sul, na Austrália e na Argentina, entre outros países. As condições ambientais brasileiras mostram-se favoráveis à infecção do patógeno por um longo período, acarretando em uma maior severidade da doença em comparação com outros países. Desta forma, estas características peculiares inviabilizam a importação de modelos de controle, evidenciando a necessidade do desenvolvimento de estratégias efetivas de detecção e controle da MPC adequadas às nossas condições.

Estudos relacionados à epidemiologia da doença vem de encontro com a real necessidade de obter-se um maior embasamento a respeito da estrutura e comportamento do patossistema Guignardia citricarpa - citros, em nossas condições, com o objetivo de 
estabelecer estratégias de controle da doença em pomares comerciais destinados tanto ao comércio de fruta fresca como para indústria, implicando no uso racional de agroquímicos com conseqüente redução dos custos de produção para o citricultor. 


\section{REVISÃO DE LITERATURA}

\subsection{A ma ncha preta dos citros}

\subsubsection{Distribuição geográfica e sintomatologia}

A mancha preta ou pinta preta dos citros, cujo agente causal é o fungo Guignardia citricarpa Kiely [Phyllosticta citricarpa (McAlp.) van der Aa.], foi relatada pela primeira vez na Austrália, em 1895, afetando frutos de laranjeira doce 'Valência' (Kiely, 1948). Em 1925 a doença foi observada na África do Sul (Doidge, 1929), onde rapidamente tornou-se o principal problema fitossanitário da citricultura daquele país (Schutte et al., 1997). Nos anos subseqüentes a doença foi relatada em outros países, entre eles China, Filipinas, Indonésia, Japão, Hong Kong e Taiwan, na Ásia; Swazilândia, Quênia, Nigéria, Zimbabwe, Rodésia e Moçambique, na África; e Argentina, Peru, Uruguai, Venezuela e Brasil, na América do Sul (Kotzé, 1988; Feichtenberger, 1996; Feichtenberger et al., 1997; Timmer et al., 2000). No Brasil, a primeira constatação ocorreu em 1980 no Rio de Janeiro (Robbs et al., 1980), afetando pomares comerciais de mexerica do 'Rio' em São Gonçalo e Itaboraí, na baixada costeira fluminense (Robbs, 1990; Robbs \& Bittencourt, 1995). Atualmente, além do Rio de Janeiro, a doença está presente oficialmente em mais quatro Estados brasileiros: Rio Grande do Sul, São Paulo, Minas Gerais e Espírito Santo. No Rio Grande do Sul a constatação da doença ocorreu em 1986, no vale do Caí, afetando tangerineiras 'Montenegrina' (Feichtenberger, 1996). Em São Paulo a doença foi constatada em 1992 nos municípios de Conchal e Engenheiro Coelho, afetando limoeiros e laranjeiras doces de maturação tardia (Goes \& Feichtenberger, 1993). A doença, hoje, pode ser 
encontrada de forma endêmica em toda a região citrícola de Limeira (Feichtenberger, 1996; Goes, 1998). Em Minas Gerais, a presença da doença foi confirmada em 2001, na região de Guaxupé, afetando laranjeiras doces. No Espírito Santo a doença foi relatada no sul do Estado em 2002 (Costa et al., 2003).

A mancha preta dos citros causa danos em todas as espécies cítricas de valor comercial, exceção feita à laranjeira azeda (Citrus aurantium L.) (Kotzé, 1981) e à limeira ácida 'Tahiti' (Citrus latifolia Osbeck). Em laranjeiras doces, os sintomas são mais severos nas variedades tardias, como 'Valência' e 'Natal' (Feichtenberger, 1996). A espécie mais sensível à mancha preta é o limoeiro verdadeiro [Citrus limon (Burm.)].

O patógeno Guignardia citricarpa é específico de citros (Baayen et al., 2002), causando lesões em ramos, folhas e frutos. Entretanto, os sintomas em laranjeiras doces são visíveis e problemáticos apenas em frutos. As lesões ficam limitadas ao flavedo (Cardoso Filho, 2003), depreciando os frutos para a comercialização no mercado interno de fruta fresca e restringindo as exportações para a União Européia, maior importador dos frutos cítricos brasileiros. A doença é considerada quarentenária A1 na União Européia, por não estar presente em seus países membros. A tolerância em relação a frutos importados com sintomas da doença é zero. A MPC não modifica as qualidades internas dos frutos (Fagan \& Góes, 2000), podendo estes serem utilizados na produção de suco cítrico concentrado (Timmer et al., 2000).

O controle da doença mal efetuado, assim como sua falta, pode ocasionar, em áreas com alta pressão de inóculo, perdas de até $80 \%$ na produção, devido à queda prematura dos frutos (Klotz, 1978). Entretanto, mesmo em níveis baixos de severidade, a doença pode ocasionar queda prematura de frutos (Fagan \& Góes, 1999).

A literatura internacional cita quatro diferentes sintomas associados à mancha preta dos citros: mancha dura, falsa melanose, mancha sardenta e mancha virulenta (Timmer et al., 2000). No Brasil, entretanto, já foram relatados seis diferentes sintomas em frutos relacionados à mancha preta dos citros, sendo eles: Mancha dura - a mais comum e típica lesão. Geralmente começa a aparecer no período que inicia a mudança da coloração dos frutos. As lesões apresentam o centro necrótico deprimido, marromclaro, e as bordas salientes, marromescuras. Em frutos mais esverdeados a lesão é 
circundada por um halo amarelado. Em frutos mais maduros a lesão é circundada por um halo esverdeado. Uma característica típica dessa lesão é a presença de pontos negros em seu interior, que se constituem nos corpos de frutificação do fungo, os picnídios. Falsa melanose - são manchas escuras e pequenas, dispersas ou agregadas nos frutos, que normalmente aparecem com estes ainda verdes. Este sintoma pode ser confundido com os de outra doença fúngica, a melanose (Diaporthe citri). Entretanto, nesta última, as lesões são ásperas quando comparadas às da falsa melanose. Mancha sardenta pequenas lesões deprimidas e avermelhadas que geralmente ocorrem no período de maturação dos frutos e na pós-colheita. Mancha rendilhada - são lesões superficiais que atingem grandes áreas dos frutos, quando estes ainda apresentam se verdes. Estas lesões não apresentam corpos de frutificação. Mancha trincada - a expressão dos sintomas está associada à presença do ácaro da falsa ferrugem (Phyllocoptruta oleivora). As lesões são arredondadas, ocorrendo em frutos ainda verdes. Com a maturação dos frutos as lesões apresentam trincas em sua superfície, não apresentando corpos de frutificação. Mancha virulenta - este sintoma caracteriza-se por ser a coalescência das lesões dos diferentes tipos de sintomas, atingindo, portanto, grandes áreas da superfície dos frutos (Fundecitrus, 2003).

Os sintomas da mancha preta são favorecidos por vários fatores, dos quais os mais importantes são a radiação solar intensa e as altas temperaturas (Feichtenberger, 1996). As diferentes manifestações dos sintomas, provavelmente, estão associadas à suscetibilidade do tecido no momento da infecção e às condições climáticas prevalecentes durante e após a infecção.

\subsubsection{Ciclo da doença}

Guignardia citricarpa pertence à classe loculoascomiceto. Em sua fase sexual, produz pseudotécios em folhas cítricas em decomposição no solo. Os pseudotécios, por apresentarem fototropismo positivo, formam suas estruturas no lado da folha caída ao solo voltado para cima. Em seu interior são formados vários ascos bitunicados de formato cilíndrico-clavado, cada um com oito ascósporos (Kotzé, 1988). A maturação 
dos ascósporos dura entre 40 e 180 dias, a contar da queda das folhas (Kotzé, 1981). A produção de ascósporos é favorecida pela alternância de períodos secos e úmidos, situação freqüentemente observada durante a estação chuvosa do ano. Quando os pseudotécios estão maduros e úmidos, ocorre a liberação ativa dos ascósporos sendo estes ejetados a uma altura de, aproximadamente, $1 \mathrm{~cm}$ (Kiely, 1948; Kotzé, 1963). A disseminação dá-se por correntes de ar, as quais levam este tipo de esporo a curtas e longas distâncias. Em contato com o tecido vegetal, os ascósporos aderem-se à sua superfície devido à mucilagem existente nas extremidades do esporo. Na presença de água livre, por períodos superiores a 24 horas, os ascósporos germinam formando seqüencialmente o tubo germinativo e o apressório (Timmer, 1999). A penetração no tecido do hospedeiro é direta. Após a penetração, forma-se uma massa micelial na região sub-cuticular. $\mathrm{O}$ fungo permanece neste estado quiescente até o retorno de suas atividades, com período de incubação que varia entre 4 e 6 meses (Timmer, 1999).

Até o momento não são conhecidos os processos fisiológicos que levam à formação dos diferentes tipos de sintomas da doença e sua expressão em diferentes períodos de desenvolvimento do fruto.

Os conídios de Phyllosticta citricarpa são produzidos em picnídios, os quais são formados em lesões de frutos, ramos e folhas. Quando os picnídios estão maduros, em seu ostíolo emergem os conídios envolvidos por uma substância mucilaginosa. A água, em contato com o ostíolo, solubiliza a mucilagem e carrega os conídios em suspensão até a superfície de órgãos suscetíveis próximos, onde novas infecções podem ocorrer. Assim como os ascósporos, os conídios germinam na superfície de órgãos suscetíveis formando apressórios. Sua infecção é direta e forma uma massa de micélio que permanece quiescente na região sub-cuticular do órgão infectado. Contudo, ao contrário dos ascósporos, os conídios, por serem disseminados por água, somente conseguem atingir tecidos do hospedeiro que estão a curtas distâncias da fonte de inóculo (Kotzé, $1981 ; 1988)$. 


\subsubsection{Epidemiologia da doença}

Apesar de trabalhos epidemiológicos com a mancha preta dos citros estarem sendo feitos nas condições do Estado de São Paulo (Baldassari, 2001; Spósito et al., 2001, 2003; Reis, 2002; Schinor, 2002), alguns pontos importantes do ciclo da doença ainda precisam ser elucidados. A literatura internacional, especialme nte aquela oriunda da Austrália e da África do Sul, atribui aos ascósporos de G. citricarpa a responsabilidade exclusiva pelas epidemias (Kiely, 1948; 1949; McOnie, 1964a; 1964b; 1965; 1967; Kotzé, 1981; 1988; 1996; Schutte et al., 1997). Aos conídios da fase assexual ( $P$. citricarpa) não é atribuída importância epidemiológica significativa. Kiely (1948), observou por vários anos, na Austrália, que sintomas severos de mancha preta ocorriam muito mais em frutos da parte superior da copa da planta, do que da sua parte inferior. Kiely, neste trabalho, supôs que se os conídios tivessem importância epidemiológica, a doença seria mais severa na parte inferior da copa, assim como ocorre com outras doenças cítricas disseminadas por água, como é o caso da melanose (Diaporthe citri Wolf.). Kotzé (1963), na África do Sul, observou que em média 52,8 \% dos frutos da metade superior das plantas apresentavam sintomas de mancha preta, concluindo, também, que os conídios não tinham importância epidemiológica. Adicionalmente, Kiely (1948) reportou que a intensidade da mancha preta era a mesma em plantas de variedades tardias onde havia sobreposição de frutos maduros (fonte de conídios) e de frutos novos (suscetíveis) quando comparadas a plantas em que não havia essa sobreposição. A conclusão desses trabalhos levou os autores a inferirem que a mancha preta dos citros comporta-se como monocíclica na África do Sul e na Austrália. Entretanto, McOnie (1964) considera os conídios formados em lesões nos frutos perigosos quando a prática de remoção de todos os frutos antes da próxima florada, devido a medidas de sanitização para pragas, não é efetuada. O comportamento da doença no Brasil, mais precisamente em São Paulo, devido às condições ambientais assim como o manejo do pomar, aparenta ser diferente (Feichtenberger, 1996; Goes, 1998). Schinor (2001), avaliando a incidência e a severidade da mancha preta em diferentes extratos verticais da planta, observou que, para as condições de São Paulo, a 
intensidade da doença foi menor na parte da copa superior a dois metros de altura. Este resultado sugere uma provável importância relativa dos conídios no incremento da doença em condições de campo.

\subsubsection{Controle e danos ocasionados pela doença}

Os princípios de Whetzel (Kimati \& Bergamin Filho, 1995) envolvidos no controle da mancha preta dos citros são: exclusão - evitando a introdução do patógeno em áreas onde a doença não fora constatada, por meio de plantio de mudas sadias; erradicação - reduzindo a população do patógeno a níveis de doença aceitáveis, por meio da retirada de frutos temporões com sintomas e antecipando a colheita de frutos de variedades tardias para antes da florada seguinte; terapia - reduzindo a população do patógeno com tratamentos químicos curativos e com tratos culturais como a poda e o manejo do mato; proteção - com o uso de fungicidas protetores; regulação modificando as condições que favorecem o desenvolvimento da doença (Feichtenberger, 1996).

Destes princípios, poucos são executáveis. A prevenção da introdução do patógeno pelo uso de mudas sadias (exclusão) tem como problema o fato de as folhas de laranjeiras doces serem assintomáticas, além da falta de uma metodologia de amostragem confiável em viveiros. Para reduzir a possibilidade desse tipo de introdução, o produtor deve adquirir mudas de regiões onde a doença ainda não esteja presente. A determinação da época da colheita das diferentes variedades é ditada por contratos comerciais estabelecidos entre as indústrias de suco de laranja e os produtores. Mudanças na época da colheita, que contribuem para a erradicação, não podem, portanto, ser efetuadas unilateralmente pelo produtor. $\mathrm{O}$ controle do ambiente (regulação) em áreas extensas é praticamente impossível. Os produtores para mercado de fruta fresca precisam plantar em áreas com temperaturas amenas, condição sine qua non para que os frutos tenham uma melhor coloração. Nessas áreas, o clima é ideal para o desenvolvimento da doença. Portanto, os princípios da proteção e da terapia são os mais apropriados para o controle da mancha preta. Os fungicidas, as dosagens (Goes et 
al., 1990; Aguilar-Vildoso et al., 1999; Spósito et al., 1999; Feichtenberger et al., 2000), a época de aplicação (Spósito et al., 2000; Reis et al.,2001) e o intervalo entre aplicações (Feichtenberger et al., 2003), já estão bem definidos para o controle da doença. Entretanto, pouco ainda foi feito em relação ao manejo do pomar. O depósito do mato sobre as folhas de citros caídas, com o intuito de reduzir a disseminação de ascósporos de G. citricarpa (Schutte \& Kotzé, 1997), é estratégia que vem sendo utilizada por citricultores da região sul do Estado de São Paulo. Para que outras estratégias possam ser adotadas, há necessidade de melhor compreender o patossistema Guignardia citricarpacitros, nas nossas condições.

Estimativas confiáveis dos prejuízos causados por doenças constituem-se num pré-requisito importante para o desenvolvimento de qualquer programa bem sucedido de controle de doenças, independentemente do método a ser utilizado: controle químico, variedades resistentes, práticas culturais, organismos antagônicos ou controle integrado. Quantificar o prejuízo que a doença pode causar assim como o custo de seu controle é essencial para a adoção do melhor manejo (Bergamin Filho, 1995a).

A relação entre intensidade de doença e redução na produção é conhecida como função de dano. Ensaios que contenham parcelas com plantas sadias e parcelas com plantas exibindo diferentes níveis de doença são geralmente empregados para o estabelecimento da função de dano, de tal modo a obter um conjunto de variáveis independentes (níveis de doença) que possa ser relacionado com um conjunto de variáveis dependentes (níveis de dano). Experimentos deste tipo exigem a integração de diferentes conhecimentos, dentre os quais são indispensáveis a quantificação da doença, a determinação do estádio de desenvolvimento do hospedeiro e a estimativa da curva de progresso da doença. A quantificação da produção é tão importante neste tipo de experimento quanto a quantificação da doença (Bergamin Filho, 1995a). Nenhuma estimativa dos danos causados pela mancha preta publicada na literatura, até o momento, utilizou essa abordagem. 


\subsection{Ferramentas de análise de epidemias}

A epidemiologia é a ciência que estuda as interações entre patógenos e hospedeiros sob a influência do ambiente e do homem (Kranz, 1974). O conhecimento destas interações é imprescindível não só para a compreensão da doença em si, mas principalmente para a elaboração da estratégia de controle, visando interferir em seu ciclo (Bergamin Filho \& Amorim, 1996). Para o melhor entendimento de um sistema, tanto a análise temporal, cuja essência é a compreensão do sistema ao longo do tempo, quanto a análise espacial, que tem por objetivo determinar o padrão de distribuição da doença no espaço, são utilizadas como ferramentas epidemiológicas.

\subsubsection{Análise temporal}

A análise temporal pode ser entendida como a evolução da interação entre os componentes do patossistema, estabelecida por dados acumulados de incidência e severidade e retratada pela curva de progresso da doença (Vanderplank, 1963; Kranz, 1974). A curva de progresso da doença expressa a proporção de doença versus tempo e pode caracterizar, de acordo com o modelo ajustado, através de seus parâmetros, a época de início da epidemia, a quantidade de inóculo inicial $\left(x_{0}\right)$, a taxa de aumento da doença $(r)$, a forma da curva de progresso da doença, a área sob a curva de progresso da doença (ASCPD), as quantidades máxima $\left(x_{\max }\right)$ e final $\left(x_{f}\right)$ de doença e a duração da epidemia (Bergamin Filho, 1995b). Alguns dos modelos matemáticos mais utilizados no ajuste de dados referentes ao progresso da doença são: modelo exponencial, modelo logístico, modelo de Gompertz e modelo monomolecular (Bergamin Filho \& Amorim, 1996).

O modelo exponencial tem como característica a proporcionalidade entre a velocidade de aumento da doença com a própria quantidade de doença, e é expresso pela equação diferencial: $d x / d t=r_{e} x$, em que $d x / d t$ é a velocidade da doença, $x$ a quantidade de doença e $r_{e}$ é a taxa de aumento da doença. Essa equação quando integrada descreve a variação da doença $(x)$ no tempo $(t)$, ou seja $x=x_{0} \exp \left(r_{e} t\right)$, em que $x$ é a quantidade de 
doença no tempo $t, x_{0}$ a quantidade de doença em $t_{0}$ e $r_{e}$ é a taxa de aumento da doença. Esse modelo por sua simplicidade, é utilizado em fases iniciais de epidemias, para quantidades de doença inferiores a 5\% (Vanderplank, 1963).

O modelo logístico confunde-se com o modelo exponencial quando a quantidade de doença é inferior a 5\%, entretanto, acima deste valor os modelos se diferenciam, pois, além da velocidade de aumento da doença ser proporcional à própria quantidade de doença, como no caso do modelo exponencial, também é proporcional à quantidade de tecido sadio. A equação diferencial do modelo logístico é escrita como: $d x / d t=r_{L} x(1-$ $x)$, em que $r_{L}$ é a taxa de aumento da doença e $(1-x)$ representa a quantidade de tecido sadio (Campbell \& Madden, 1990; Bergamin Filho \& Amorim, 1996). A equação integrada é representada por $x=1 /\left(1+\left(\left(1 / x_{0}\right)-1\right) \exp \left(-r_{L} t\right)\right)$, a qual descreve uma curva sigmóide de $x$ versus $t$, simétrica com ponto de inflexão em torno de $x=0,5$. Portanto, há incrementos crescentes até $50 \%$ de doença, seguidos de incrementos reduzidos até estes tenderem a zero, ou seja, 100\% de doença (Bergamin Filho, 1995b) .

$\mathrm{O}$ modelo de Gompertz é muito parecido com o modelo logístico. A equação diferencial é representada como: $d x / d t=r_{G} x(-\ln (x))$, em que $r_{G}$ é a taxa de aumento da doença específica para este modelo. Quando integrada a equação diferencial, a equação resultante $x=\exp \left(-\left(-\ln \left(x_{0}\right)\right) \exp \left(-r_{G} t\right)\right)$, descreve uma curva sigmóide, a exemplo do modelo logístico, entretanto como o ponto de inflexão em $x=0,37$. A curva originária da plotagem de $x$ versus $t$ apresenta um crescimento mais acentuado no início da doença (Campbell \& Madden, 1990; Bergamin Filho \& Amorim, 1996).

O modelo monomolecular diferente dos modelos descritos anteriormente (exponencial, logístico e Gompertz), não apresenta proporcionalidade entre a velocidade de aumento da doença $(d x / d t)$ com a quantidade de doença $(x)$, e sim entre a velocidade de aumento da doença $(d x / d t)$ com ao inóculo inicial $\left(x_{0}\right)$ e a taxa de aumento da doença $\left(r_{M}\right)$, que é constante. A equação diferencial deste modelo é expressa por $d x / d t=r_{M}(1$ $x$ ). Neste caso $d x / d t$ apresenta incrementos sempre menores no tempo e que aproxima-se de zero sempre que $x$ se aproxima de 1 . A equação diferencial quando integrada gera a equação $x=1-\left(1-x_{0}\right) \exp \left(-r_{m} t\right)$, que, plotada contra o tempo, produz uma curva côncava em 
relação à abscissa, aproximando-se assintoticamente da quantidade máxima de doença (Bergamin Filho \& Amorim, 1996).

A escolha do melhor modelo é feita pela análise de regressão do ajuste dos modelos aos dados representados. O grau de ajuste de cada modelo aos dados é avaliado em função dos valores do coeficiente de determinação $\left(R^{2}\right)$ e do padrão dos resíduos (Cornell \& Berger, 1987; Neter et al., 1996).

\subsubsection{Análise espacial}

Patógenos de plantas possuem diferentes agentes de dispersão como o vento, a água, vetores, material vegetal contaminado, ou o homem com suas ferramentas e suas máquinas (Campbell \& Madden, 1990). O padrão espacial de uma doença depende não só da forma de dispersão do patógeno, como também da arquitetura das plantas hospedeiras e do arranjo destas no campo (Gilligan, 1982).

A análise do padrão de distribuição de uma doença possibilita o desenvolvimento de hipóteses biológicas e ambientais plausíveis, associando essa distribuição com a presença de propágulos do patógeno ou microclima favorável (Campbell \& Madden, 1990). Essa análise é necessária no desenvolvimento de modelos e simulações, além de ser útil para a montagem de experimentos e programas amostrais para estudos epidemiológicos e de manejo da doença.

A distribuição espacial de uma doença em uma área pode seguir três tipos de padrões: regular, aleatório ou agregado. Em doenças causadas por patógenos de plantas, os arranjos aleatórios e agregados são mais comumente observados, sendo rara a presença de arranjos regulares (Campbell \& Madden, 1990). A distribuição aleatória de uma doença indica que não há correlação entre a localização de indivíduos sintomáticos dentro de uma área (Madden, 1989). A distribuição agregada de uma doença indica que há uma correlação entre indivíduos sintomáticos, ou seja, há uma alta probabilidade de que indivíduos sintomáticos estejam próximos uns dos outros (Madden, 1989).

Entre os métodos de análise de arranjos espaciais, o estudo da sequiência ordinária de plantas doentes e sadias, assim como a análise por quadrats dispostos por 
malhas em uma área amostral, são usualmente utilizados (Campbell \& Madden, 1990). O estudo de sequiências de plantas doentes e sadias é utilizado principalmente para testar hipóteses relacionadas à disseminação de patógenos (Dhanvatari \& Dirks, 1987; Gottwald et al., 1993).O estudo através de quadrats dispostos em malhas, apresenta diferentes técnicas de análises, entre elas o índice de dispersão e a lei de Taylor.

Outra técnica que vem sendo utilizada em estatística espacial é a análise de padrões pontuais. Esta ferramenta consiste em observar dados disponíveis em um determinado espaço e através de métodos e modelagem, procura verificar se os eventos observados apresentam comportamento sistemático, como por exemplo, agregação, regularidade ou aleatoriedade.

\subsubsection{1 Índice de Dispersão}

O índice de dispersão $(D)$ é utilizado em estudos epidemiológicos para indicar tipos de padrões espaciais: regulares $(D<1)$, aleatórios $(D=1)$ ou agregados $(D>1)$ (Upton \& Flingleton, 1985). O índice de dispersão baseia-se na relação entre a variância e a média do conjunto de dados da área experimental considerada. Entretanto, a rigor, o índice de dispersão é a relação entre a variância observada e a variância teórica do processo de estudo (Bergamin Filho et al., 2002). Para estudos de incidência (ex.: plantas sintomáticas em uma área amostral), em que a variável é binária e apresenta distribuição binomial, a variância teórica do processo de estudo é a variância binomial, calculada por $V_{b i n}=p(1-p) / n$, em que $p$ é a incidência da doença na parcela e $n$ o número de plantas por quadrat. A variância observada é calculada por $V_{o b s}=\mathrm{O}\left(X_{1}-n p\right)^{2} / n^{2}(N-$ 1), em que Ó $X_{l}$ é o somatório do número de plantas sintomáticas em cada quadrat $i$ e $N$ é o número total de quadrats em cada área (Bergamin Filho et al., 2002).

Apesar de ser muito utilizado, o índice de dispersão tem como limitação rão levar em consideração a posição relativa de cada medida (Nicot et al., 1984). 


\subsubsection{Lei de Taylor}

A lei de Taylor é uma ferramenta epidemiológica que representa através de parâmetros de sua equação o grau de agregação de uma dada espécie. A partir de dados de distribuição espacial de diversas populações de uma espécie, pode-se relacionar linearmente o logaritmo da variância observada $\left(V_{o b s}\right)$ e o logaritmo da média, pela equação: $\log \left(V_{o b s}\right)=\log (A)+b \log$ (média). O parâmetro $b$ é empregado como índice de agregação (Taylor, 1961). Quando $b>1$, o padrão espacial é agregado, para $b=1 \mathrm{o}$ padrão é aleatório e no caso de $b<1$ o padrão é regular.

Para dados binários, como os de incidência de doença, a equação da lei de Taylor é modificada (Madden \& Hughes, 1995), apresentando a seguinte forma: $\log \left(V_{o b s}\right)=\log$ $(A)+b \log \left(V_{b i n}\right)$. Neste caso, a distribuição espacial aleatória é indicada por $b=1$ e $A=$ 1 , onde a variância observada é igual à variância binomial $\left[\log (A)=0, \log 0 \log \left(V_{\text {obs }}\right)=\right.$ $\log \left(V_{b i n}\right)$ ], isto é o mesmo que dizer que $D=1$ para todo o conjunto de dados (Bergamin Filho et al., 2002). Para $b=1$ e $A>1$, o $D$ é fixo e igual a $A$, para todo conjunto de dados, ou seja o $D$ não varia com a incidência $(p)$. Caso $b>1$ o $\log \left(V_{o b s}\right)$ aumenta com o log $\left(V_{\text {bin }}\right)$, isto é, o $D$ varia com as mudanças em $p$ (Bergamin Filho et al., 2002).

A lei de Taylor, diferentemente do índice de dispersão, avalia o padrão espacial de um conjunto de dados, permitindo obter uma visão dinâmica de uma área em diferentes períodos ou pela incidência de doença observada em diferentes localidades (Bergamin Filho et al., 2002).

\subsubsection{Função K de Ripley}

A função K de Ripley, é utilizada em análises de padrões pontuais, sendo um bom indicador de estruturas espaciais (Ripley, 1981). Este método analisa propriedades dos dados conhecidas como de segunda ordem, ou seja, dependência espacial. Nesta análise compara-se o número médio de pontos observados em segmentos circulares de uma área amostral com o número de pontos esperados se estes pontos fossem distribuídos aleatoriamente de acordo com um processo de Poisson. Esse método utiliza 
toda a área espacial amostral, não sendo necessário fracioná-la para estudos de comportamento sistemáticos: agregação, regularidade ou aleatoriedade.

A função K é definida por: $\ddot{e} K(h)=E$, em que $\ddot{e}$ é a intensidade, ou o número médio de eventos por unidade de área, $E$ é o número de eventos dentro de uma distância $h$ em um evento arbitrário e $K(h)$ descreve as características de um processo pontual em várias escalas de distância.

A função K pode ser estimada pela fórmula (Ripley, 1981):

$$
K(h)=\frac{\lambda^{-1} \sum_{i=1}^{n} \sum_{j=1}^{n} I_{h}\left(E_{i}, E_{j}\right)}{n} \quad \text { para } i \quad j \text { e } t>0
$$

No caso de um processo aleatório, sem dependência espacial temrse $K(h)=ð h^{2}$. Sob agregação, espera-se que $K(h) \quad \partial h^{2}$ e para regularidade $K(h) \quad \partial h^{2}$.

A fim de facilitar a interpretação gráfica da função K, normaliza-se a função, utilizando a seguinte fórmula (Kenkel, 1988):

$$
L(h)=\sqrt{\frac{K(h)}{\pi h^{2}}}-h
$$

onde plota-se os valores de $L(h)$ contra a distância $(h)$. Valores positivos indicam atração espacial, ou seja, agregação. Valores negativos indicam repulsão ou regularidade. $\mathrm{O}$ zero representa aleatoriedade (Kenkel, 1988). 


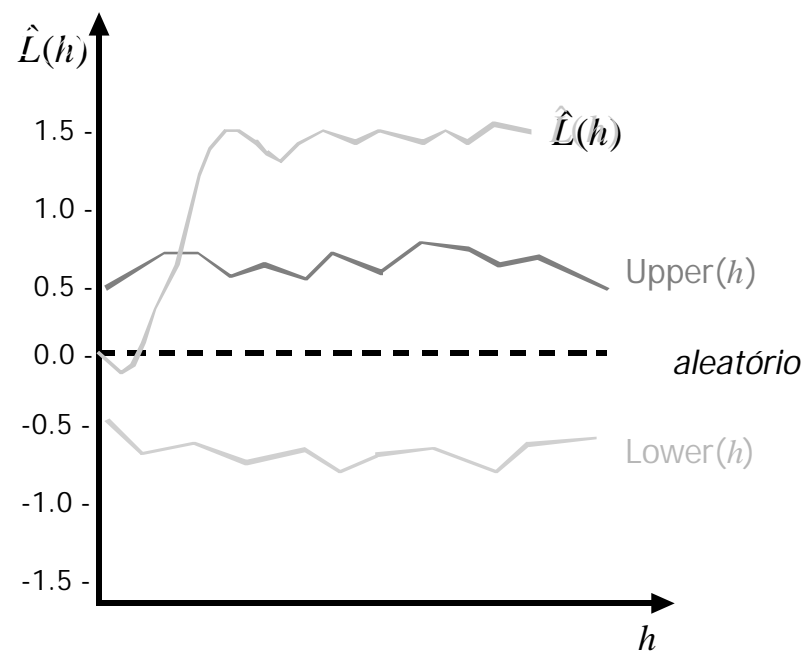

Figura 1 - Esquema gráfico da Função K de Ripley normatizada $[L(h)]$, em que valores negativos indicam regularidade, positivo agregação e o valor zero a aleatoriedade dos dados. O intervalo de confiança é representado pelo envelope formado pelos valores $\operatorname{Upper}(h)$ e lower $(h)$ 


\section{ELABORAÇÃO E VALIDAÇÃO DE ESCALA DIAGRAMÁTICA PARA AVALIAÇÃo dA SEVERIDAde DA MANCHA PRETA EM FRUTOS CÍTRICOS}

\section{Resumo}

Uma escala diagramática, abrangendo os dois tipos prevalentes de sintomas de mancha preta em frutos cítricos, os de mancha dura e de falsa melanose, foi desenvolvida para padronizar a avaliação da severidade da doença. A escala foi elaborada considerando os limites máximos e mínimos de severidade da doença observados no campo. Os valores intermediários seguiram incrementos logarítmicos para os sintomas do tipo mancha dura $(0,5 ; 1,7 ; 5,0 ; 11,5 ; 22,5$ e $49,0 \%)$ e do tipo falsa melanose $(1,1 ; 4,5 ; 15,0 ; 31,0 ; 53,0$ e $68,0 \%)$. Para a validação da escala, seis avaliadores quantificaram a severidade da doença a partir das imagens digitalizadas de 50 frutos com diferentes níveis de doença. Inicialmente, a estimativa da severidade foi feita sem auxílio da escala. Em seguida, os mesmos avaliadores, utilizando a escala diagramática proposta, estimaram a severidade nos mesmos frutos avaliados anteriormente. As avaliações com a escala diagramática foram mais precisas e acuradas nas estimativas de todos os avaliadores e proporcionaram maior reprodutibilidade entre avaliações de diferentes avaliadores. A escala diagramática proposta foi considerada adequada para estimar a severidade da mancha preta nos frutos e será usada em estudos epidemiológicos e de avaliação de estratégias de controle desta doença. 


\section{Summary}

\section{Elaboration and Validation of Diagrammatic Scale to Evaluate the Black Spot Severity in Citrus Fruit}

A diagrammatic scale, with the most commonly symptoms of black spot in citrus fruit, hard spot and false melanose types, was developed to standardize its severity assessment. The scale was elaborated considering the maximum and minimum limits of disease severity observed in the field. The intermediate values followed logarithmic increments for hard spot $(0.5,1.7,5.0,11.5,22.5$, and 49.0\%) and false melanose (1.1, $4.5,15.0,31.0,53.0$, and 68.0\%) symptoms. To validate the scale, six raters quantified the disease severity of digitalized images of 50 fruit with black spot symptoms. Initially, the estimates of severity were done without the use of the scale. Then, the raters, estimated the severity of the same fruit previously assessed using the proposed diagrammatic scale. Assessments with the diagrammatic scale were of greater precision and higher accuracy for all raters, besides higher reproducibility among different raters. The proposed diagrammatic scale was considered adequate to estimate black spot severity in citrus fruit and will be used in epidemiological studies and control strategies evaluation of this disease.

\subsection{Introdução}

A mancha preta dos citros, incitada pelo fungo Guignardia citricarpa Kiely, é doença de importância econômica, principalmente para a região sul do Estado de São Paulo (Feichtenberger et al., 1997). O patógeno causa lesões em frutos, ocasionando queda precoce, podendo reduzir a produção em até 80\% (Klotz, 1978). Os frutos com sintomas também são depreciados para a comercialização no mercado de fruta fresca, resultando menor rentabilidade para o citricultor que atende este setor. 
A doença manifesta-se de diversas formas nos frutos, sendo relatados até o momento, seis tipos de sintomas diferentes (Aguilar-Vildoso et al., 2002). Os sintomas mais comuns observados em frutos são os do tipo mancha dura e os da falsa melanose (Kotzé, 1981; 1988). O sintoma do tipo mancha dura caracteriza-se por lesões circulares, deprimidas, com bordos salientes de coloração marrom e na maioria das vezes por apresentar pontuações negras no seu interior, que correspondem aos picnídios. Este tipo de sintoma normalmente ocorre no período de mudança da coloração dos frutos. $\mathrm{O}$ sintoma do tipo falsa melanose caracteriza-se por minúsculas e numerosas pontuações escuras, dispersas ou agregadas, que normalmente aparecem em frutos ainda verdes (Feichtenberger et al., 1997).

A quantificação de doenças é fundamental para estudos epidemiológicos e para avaliação de estratégias de controle. A quantificação de uma variável que expresse a intensidade de doença, quer seja ela medida pela incidência ou pela severidade, é necessária, tanto para descrever o progresso da epidemia e sua relação com o clima ou com medidas de controle, quanto para validação de modelos de previsão ou para a aplicação do manejo integrado. Portanto, erros na quantificação da doença podem ser magnificados na análise epidemiológica subseqüente, interferindo em maior ou menor grau, nas conclusões alcançadas (Campbell \& Madden, 1990). Para que os erros sejam minimizados, o método utilizado na quantificação da doença deve ser capaz de fornecer resultados acurados, precisos e reproduzíveis.

A avaliação da mancha preta dos citros tem sido realizada pela incidência da doença, quando os frutos são destinados ao mercado de fruta fresca, ou pela severidade da doença, quando os frutos são destinados à produção de suco concentrado. A quantificação da severidade é comumente realizada com o auxílio de escalas diagramáticas representando frutos com diferentes porcentagens de área ocupadas pelas lesões. As escalas são utilizadas na orientação da estimativa visual de tal modo que a avaliação torne-se mais precisa e acurada após a comparação da amostra com a representação no diagrama. Quando a avaliação visual é feita sem o auxílio de escalas diagramáticas, o avaliador pode atribuir qualquer valor no intervalo de zero a 100\% para a superfície do fruto ocupada por sintomas. $\mathrm{O}$ uso da escala permite ao avaliador situar 
sua estimativa num intervalo menor, compreendido entre dois dos níveis representados por seus diagramas (Amorim, 1995). Dessa forma, as escalas diagramáticas contribuem na redução do erro na estimativa visual da severidade de doenças.

As escalas diagramáticas devem ser simples, aplicáveis em diferentes condições e ter intervalos suficientes para representar os diferentes níveis de severidade de uma determinada doença. Na elaboração de uma escala diagramática, alguns aspectos devem ser considerados, como as quantidades mínima e máxima de doença observadas no campo e representadas na escala, a representação dos sintomas da maneira mais próxima possível da realidade e os níveis de severidade respeitando as limitações da acuidade da vista humana, definidas pelas leis de estímulo-resposta de Weber e de Fechner, também conhecidas como lei de Weber-Fechner (Horsfall \& Barrat, 1945; Nutter \& Schultz, 1995). Além da boa qualidade de uma escala diagramática, as estimativas de severidade dependem da percepção visual e da experiência de cada indivíduo na avaliação de doenças.

A precisão e a acurácia das estimativas de severidade variam de acordo com o avaliador. Após a elaboração, as escalas devem ser testadas por diferentes indivíduos a fim de comprovar sua eficiência na estimativa da severidade. A precisão, medida de confiabilidade e/ou repetibilidade nas avaliações de doença (Nutter et al., 1991), pode ser quantificada pelo coeficiente de determinação de regressões lineares estabelecidas entre a severidade real e as estimativas da severidade de uma determinada amostra. A precisão será tanto maior quanto mais próximo de 1,0 for o valor do coeficiente de determinação $\left(R^{2}\right)$. A acurácia, representada pelo grau de proximidade entre a estimativa média e a realidade (Nutter et al., 1991), pode ser quantificada pelo coeficiente angular e pela interseção de linhas de regressão estabelecidas entre a severidade real e as estimativas da severidade de uma determinada amostra. A acurácia será tanto maior quanto mais próximo de 1,0 for o coeficiente angular e mais próximo de zero for a interseção.

Aguilar-Vildoso et al. (2002), publicaram uma escala diagramática para a avaliação da mancha preta dos citros, a qual vem sendo utilizada, principalmente, em ensaios de comparação de tratamentos para o controle da doença. No entanto, essa escala 
não atende às necessidades de quantificação para estudos epidemiológicos, pois a severidade máxima representada na escala é de $25 \%$, muito abaixo da severidade observada no campo na ausência de medidas de controle. Além disso, apenas sintomas do tipo mancha dura estão representados nessa escala, dificultando a avaliação de frutos com sintomas do tipo falsa melanose.

O objetivo deste trabalho foi elaborar e validar uma nova escala diagramática para avaliação da mancha preta dos citros na qual estivessem representados tanto sintomas do tipo mancha dura quanto sintomas do tipo falsa melanose.

\subsection{Material e Métodos}

Para a quantificação dos níveis representados na escala diagramática, 50 frutos das variedades 'Hamlin', 'Pera', 'Valência' e 'Natal' com ampla variação de severidade da doença (0,5\% a 68\%), foram coletados em áreas com 100\% de incidência da doença. A face externa de cada fruto, levando em consideração o seu posicionamento na planta, foi fotografada com câmera digital C-2020 Zoom Digital Camera (Olympus ${ }^{\circledR}$ ). As imagens digitalizadas foram transferidas para um microcomputador e, posteriormente, foram processadas com o programa SIARCS 3.0, elaborado e comercializado pelo Centro Nacional de Pesquisa e Desenvolvimento de Instrumentação Agropecuária da Embrapa (Jorge, 1996). Tanto a área necrosada como o halo amarelado, eventualmente presente, foram considerados como tecido doente para fins de quantificação da severidade. Os níveis mínimo e máximo de severidade foram determinados de acordo com a maior frequiência observada nos frutos coletados. Os níveis intermediários da escala foram determinados matematicamente, seguindo incrementos logarítmicos. Após estabelecidas as porcentagens de doença a serem representadas na escala, reproduziu-se um desenho padrão com área conhecida, representando um fruto cítrico, ao qual acrescentaram-se desenhos de lesões de formatos variados, distribuídos de maneira a retratar os sintomas observados no campo. Foram representados seis níveis de doença 
com sintomas do tipo mancha dura e seis níveis de doença com sintomas do tipo falsa melanose.

Para a validação da escala, seis avaliadores quantificaram a severidade da doença a partir das imagens dos 50 frutos, apresentadas com auxílio de um projetor tipo "multimedia", em duas fases. Em uma primeira fase, os avaliadores estimaram a severidade sem auxílio da escala diagramática e, em uma segunda fase, estimaram a severidade com o auxílio da mesma. Quando a escala diagramática foi utilizada, a opção pela escolha da representação dos sintomas do tipo mancha dura ou da representação dos sintomas do tipo falsa melanose ficou a critério de cada avaliador. Essa informação não foi monitorada.

Regressões lineares entre a severidade real (variável independente) e a estimada (variável dependente) foram calculadas de acordo com a metodologia de Draper \& Smith (1998) e Teng (1981), para cada avaliador, individualmente, e conjuntamente para todos os avaliadores. A acurácia das estimativas de cada avaliador e do conjunto de avaliadores foi determinada pelo teste $t$ aplicado às estimativas dos parâmetros interseção da regressão linear (a), para verificar a hipótese Ho: $a=0$, e coeficiente angular da reta $(b)$, para testar a hipótese Ho: $b=1$, ao nível de probabilidade $p=0,05$. A precisão foi estimada pelo coeficiente de determinação da regressão $\left(R^{2}\right)$ e pela variação dos resíduos (severidade estimada menos a severidade real) (Campbell \& Madden, 1990; Kranz, 1988; Nutter Jr. \& Schultz, 1995). A comparação entre os parâmetros $a$ e $b$ das estimativas sem $\left(a_{s}\right.$ e $\left.b_{s}\right)$ e com $\left(a_{c}\right.$ e $\left.b_{c}\right)$ auxílio da escala diagramática ao conjunto dos dados de todos os avaliadores foi realizada pelo teste $t$, para verificar as hipóteses Ho: $a_{s}=a_{c}$ e Ho: $b_{s}=b_{c}$, ao nível de probabilidade de $p=0,05$ (Campbell \& Madden, 1990). A reprodutibilidade das avaliações entre os diferentes avaliadores foi testada por meio de regressões lineares onde tanto a variável dependente quanto a independente foram estimativas de diferentes avaliadores. Todos os avaliadores foram confrontados entre si. Avaliou-se a precisão e acurácia das estimativas de todas as combinações. O programa Excel 97 (Microsoft ${ }^{\circledR}$ ) foi utilizado nas análises de regressão linear. 


\subsection{Resultados e Discussão}

A escala diagramática para mancha preta dos citros foi desenhada com seis níveis de severidade para os sintomas do tipo mancha dura $(0,5 ; 1,7 ; 5,0 ; 11,5 ; 22,5$ e $49,0 \%) \mathrm{e}$ seis níveis de severidade para os sintomas do tipo falsa melanose $(1,1 ; 4,5 ; 15,0 ; 31,0$; 53,0 e 68,0\%) (Figura 2).

As avaliações de severidade da mancha preta dos citros, feitas sem e com o auxílio da escala, levaram em consideração somente a face externa de cada fruto fotografado. No campo, rotineiramente avalia-se a área dos frutos mais expostas aos raios solares pois é neste local que há maior expressão dos sintomas da doença (Kotzé, 1981; 1988).

Quando a severidade da doença foi estimada sem o auxílio da escala diagramática, os avaliadores foram relativamente precisos, com coeficientes de determinação variando entre 0,85 e 0,91 para as retas de regressão entre a severidade real e a estimada (Tabela 1). Entretanto, os seis avaliadores superestimaram a severidade da doença, incorrendo em erros sistemáticos nas estimativas (Figura 3A-F). A interseção da reta ( $a$ ) foi sempre elevada, com valor médio, obtido pela regressão conjunta de todos avaliadores, de 5,26 (Figura 3G). Todos os valores de $a$ foram significativamente diferentes de zero (Tabela 1). O coeficiente angular da reta de regressão (b) também foi elevado, com um valor médio de 1,26, estatisticamente diferente de 1,0 (Tabela 1). Os valores de $b$ foram estatisticamente diferentes de 1,0 para quatro dos seis avaliadores (Tabela 1). A distribuição dos resíduos das avaliações realizadas sem o auxílio da escala diagramática apresentou estimativas com erros absolutos variando entre $-0,38$ (Figura 3F) e 44,70 (Figura 4A), sendo a média dos erros (em módulo) de todos os avaliadores igual a 7,26. 


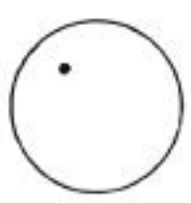

0,5

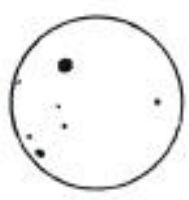

1,7

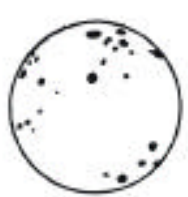

5,0

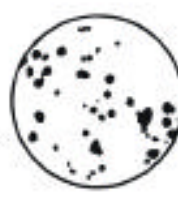

11.5

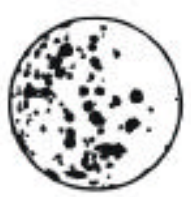

22,5

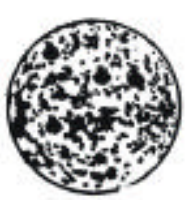

49,0

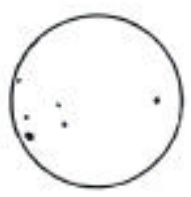

1.1

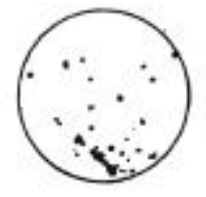

4,5

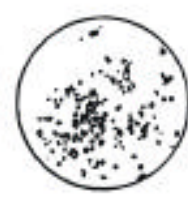

15,0

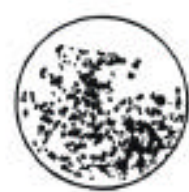

31.0

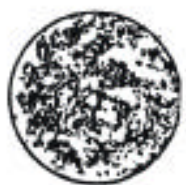

53,0

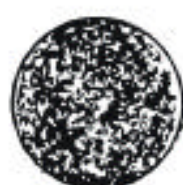

68,0

Figura 2 - Escala diagramática para avaliação da severidade (\%) da mancha preta (Guignardia citricarpa) dos citros. Os diagramas da parte superior são representações do sintoma de mancha dura e os da parte inferior, representações do sintoma de falsa melanose

Quando a avaliação foi realizada com o auxílio da escala, todos os avaliadores melhoraram sua precisão, com coeficientes de determinação variando entre 0,89 e 0,96 (Tabela 1), e reduziram os erros sistemáticos das estimativas (Figura 3H-M). O valor médio da interseção da regressão (a) foi de 2,35 (Tabela 1). O uso da escala resultou em coeficientes angulares próximos de 1,0 para quatro avaliadores e em três deles $(1,4$ e 5) não diferiram estatisticamente de 1,0 (Tabela 1). $\mathrm{O}$ valor do coeficiente angular da reta (b) de 1,02, obtido na regressão conjunta de todos os avaliadores com o uso de escala (Figura 3N), foi estatisticamente igual a 1,0 (Tabela 1). Os valores dos parâmetros $a$ e $b$ obtidos na avaliação com o auxílio da escala foram significativamente menores que os obtidos sem a escala, para o conjunto dos seis avaliadores. Houve redução nos erros absolutos para as estimativas com auxílio da escala, quando comparada com a distribuição dos resíduos das estimativas obtidas sem escala diagramática. Os erros absolutos variaram entre -2,89 (Figura 4I) e 15,03 (Figura 4L), sendo a média dos erros (em módulo) de todos avaliadores igual 2,87. A maioria dos erros absolutos observados para as estimativas obtidas por todos os avaliadores, com o auxílio da escala, ficou 
dentro de valores aceitáveis $(-10 \mathrm{a}+10 \%)$, segundo critérios adotados por programas de treinamento na quantificação de doenças, como o Distrain (Tomerlin \& Howell, 1988) e o Disease.Pro (Nutter \& Worawitlikit, 1989).

Tabela 1. Estimativas de parâmetros e coeficientes de determinação $\left(R^{2}\right)$ das equações de regressão linear calculadas entre severidade real e severidade estimada de mancha preta dos citros realizadas por seis avaliadores individualmente e para o conjunto dos mesmos, sem e com o uso de escala diagramática $(y=a+b x$, em que $y$ representa a severidade estimada e $x$, a severidade real)

\begin{tabular}{cccccccc}
\hline Avaliador & \multicolumn{3}{c}{ Sem escala } & & \multicolumn{3}{c}{ Com escala } \\
& $a^{(\mathrm{i})}$ & $b^{(\mathrm{ii})}$ & $R^{2}$ & & $a$ & $b$ & $R^{2}$ \\
\hline 1 & $8,64 *$ & $1,74 *$ & 0,91 & & $2,16 *$ & $0,98 \mathrm{~ns}$ & 0,9 \\
2 & $5,29 *$ & $1,11 \mathrm{~ns}$ & 0,88 & & $1,94 *$ & $1,13 *$ & 0,9 \\
3 & $6,29 *$ & $0,98 \mathrm{~ns}$ & 0,89 & & $1,80 *$ & $0,90 *$ & 0,9 \\
4 & $5,17 *$ & $1,22 *$ & 0,85 & & $3,65 *$ & $0,96 \mathrm{~ns}$ & 0,8 \\
5 & $4,07 *$ & $1,11 *$ & 0,89 & & $3,21 *$ & $0,95 \mathrm{~ns}$ & 0,9 \\
6 & $2,09 *$ & $1,39 *$ & 0,91 & & $1,29 *$ & $1,21 *$ & 0,9 \\
Todos & $5,26 *$ & $1,26 *$ & 0,83 & & $2,35 *$ & $1,02 \mathrm{~ns}$ & 0,9
\end{tabular}

(i) asteriscos indicam que o valor da interseção da reta $(a)$ foi diferente de zero pelo teste $t(p=0,05)$, ns indica que não houve diferença estatística significativa entre $a$ e zero pelo teste $t(p=0,05)$;

(ii) asteriscos indicam que o valor do coeficiente angular da reta de regressão $(b)$ foi diferente de um pelo teste $t(p=0,05)$, ns indica que não houve diferença estatística significativa entre $b$ e um pelo teste $t$ $(p=0,05)$.

Os coeficientes de determinação das equações de regressão linear calculadas nas comparações das estimativas dos avaliadores entre si, foram maiores quando estes utilizaram a escala diagramática do que sem a utilização desta (Tabela 2). Entretanto, não houve diferença quanto às estimativas dos parâmetros $a$ e $b$ entre os avaliadores quando estes utilizaram a escala ou não (Tabela 2). Os avaliadores, quando utilizaram a escala, foram mais precisos entre si na estimativa da severidade da doença. Do ponto de vista prático, o uso da escala diagramática aumenta a reprodutibilidade das estimativas 
obtidas por diferentes avaliadores e, portanto, a estimativa da severidade da doença poderá ser feita por qualquer avaliador, pois os resultados serão semelhantes e diferentes experimentos, conduzidos por avaliadores distintos, serão comparáveis.

Tabela 2. Estimativas de parâmetros e coeficientes de determinação $\left(R^{2}\right)$ das equações de regressão linear calculadas entre as severidades de mancha preta dos citros estimadas por diferentes avaliadores $(y=a+b x$, em que $y$ representa a severidade estimada por um avaliador e $x$, a severidade estimada por outro avaliador). As estimativas da severidade dos seis avaliadores foram confrontadas entre si, sem e com o uso de escala diagramática

\begin{tabular}{ccccccc}
\hline Comparação & \multicolumn{3}{c}{ Sem escala } & \multicolumn{3}{c}{ Com escala } \\
& $a^{(\mathrm{i})}$ & $b^{\text {(ii) }}$ & $R^{2}$ & $a$ & $b$ & $R^{2}$ \\
$1 \times 2$ & $0,52 \mathrm{~ns}$ & $0,60 *$ & 0,87 & $-0,20 \mathrm{~ns}$ & $1,11 *$ & 0,9 \\
$1 \times 3$ & $1,98 \mathrm{~ns}$ & $0,54 *$ & 0,89 & $0,09 \mathrm{~ns}$ & $0,89 *$ & 0,9 \\
$1 \times 4$ & $-0,09 \mathrm{~ns}$ & $0,66 *$ & 0,83 & $1,60 \mathrm{~ns}$ & $0,97 \mathrm{~ns}$ & 0,9 \\
$1 \times 5$ & $-0,65 \mathrm{~ns}$ & $0,60 *$ & 0,87 & $1,25 \mathrm{~ns}$ & $0,95 \mathrm{~ns}$ & 0,9 \\
$1 \times 6$ & $-3,67 *$ & $0,75 *$ & 0,86 & $-0,98 \mathrm{~ns}$ & $1,19 *$ & 0,9 \\
$2 \times 3$ & $2,34 \mathrm{~ns}$ & $0,83 \mathrm{~ns}$ & 0,89 & $0,47 \mathrm{~ns}$ & $0,78 *$ & 0,9 \\
$2 \times 4$ & $0,44 \mathrm{~ns}$ & $1,02 \mathrm{~ns}$ & 0,82 & $2,05 *$ & $0,85 *$ & 0,9 \\
$2 \times 5$ & $-0,16 \mathrm{~ns}$ & $0,92 \mathrm{~ns}$ & 0,85 & $1,78 *$ & $0,82 *$ & 0,9 \\
$2 \times 6$ & $-3,49 *$ & $1,18 *$ & 0,89 & $-0,44 \mathrm{~ns}$ & $1,03 \mathrm{~ns}$ & 0,9 \\
$3 \times 4$ & $-2,13 \mathrm{~ns}$ & $1,21 *$ & 0,89 & $1,69 *$ & $1,07 \mathrm{~ns}$ & 0,9 \\
$3 \times 5$ & $-2,39 *$ & $1,09 \mathrm{~ns}$ & 0,91 & $1,34 *$ & $1,05 \mathrm{~ns}$ & 0,9 \\
$3 \times 6$ & $-5,78 *$ & $1,34 *$ & 0,89 & $-0,76 \mathrm{~ns}$ & $1,29 *$ & 0,9 \\
$4 \times 5$ & $-0,09 \mathrm{~ns}$ & $0,87 *$ & 0,96 & $-0,03 \mathrm{~ns}$ & $0,95 \mathrm{~ns}$ & 0,9 \\
$4 \times 6$ & $-2,84 *$ & $1,07 \mathrm{~ns}$ & 0,94 & $-2,29 *$ & $1,16 *$ & 0,9 \\
$5 \times 6$ & $-2,67 *$ & $1,23 *$ & 0,97 & $-2,08 *$ & $1,20 *$ & 0,9
\end{tabular}

(i) asteriscos indicam que o valor da interseção da reta (a) foi diferente de zero pelo teste $t(p=0,05)$, ns indica que não houve diferença estatística significativa entre $a$ e zero pelo teste $t(p=0,05)$;

(ii) asteriscos indicam que o valor do coeficiente angular da reta de regressão $(b)$ foi diferente de um pelo teste $t(p=0,05)$, ns indica que não houve diferença estatística significativa entre $b$ e um pelo teste $t$ $(p=0,05)$. 

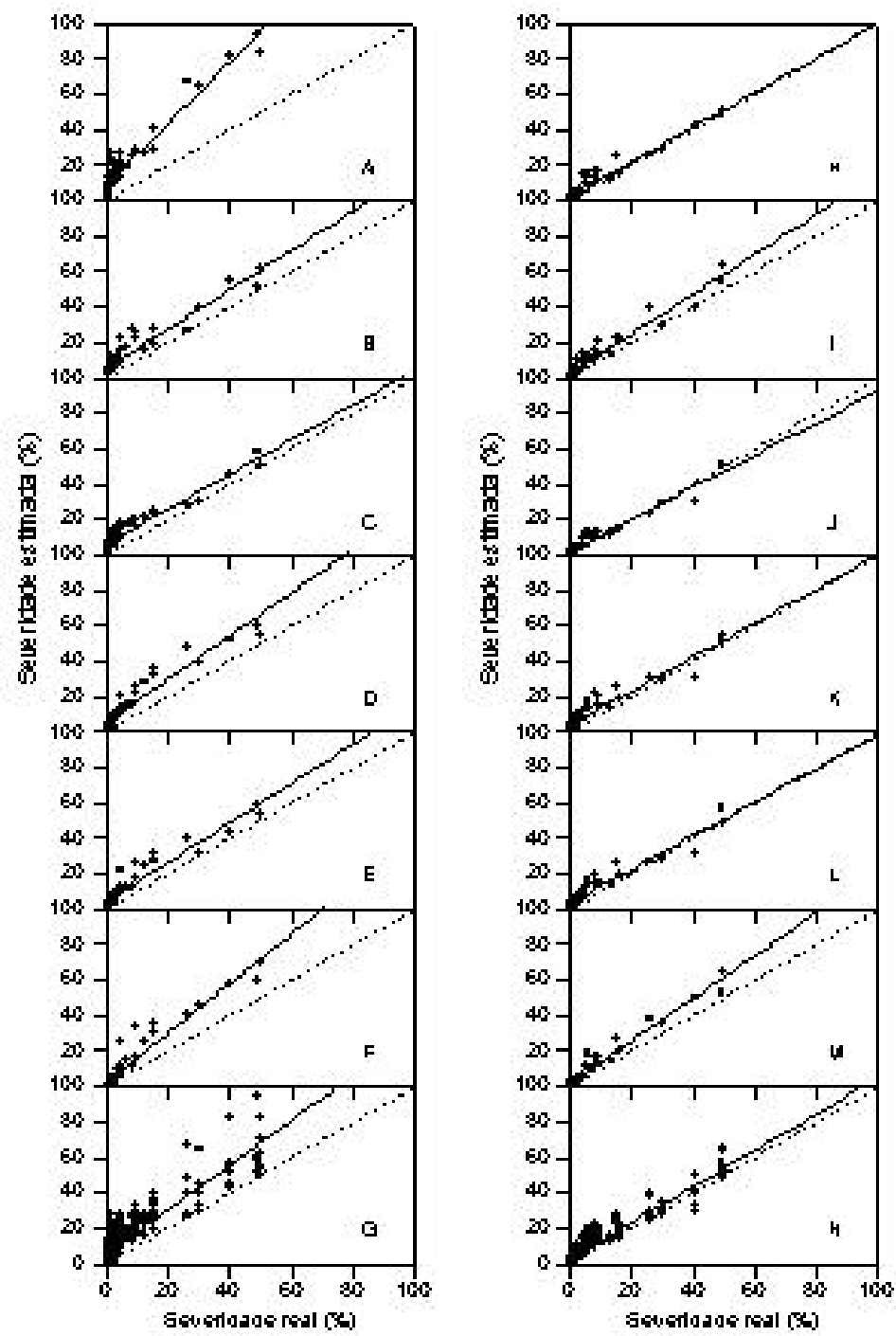

Figura 3 - Severidade estimada $(\bullet)$ sem auxílio (A-G) e com o auxílio da escala diagramática para mancha preta $(\mathrm{H}-\mathrm{N})$, por seis avaliadores: avaliador 1 (A, H), $2(\mathrm{~B}, \mathrm{I}), 3(\mathrm{C}, \mathrm{J}), 4(\mathrm{D}, \mathrm{K}), 5(\mathrm{E}, \mathrm{L})$ e $6(\mathrm{~F}, \mathrm{M})$, e pelo conjunto dos mesmos $(G, N)$. As linhas cheias representam a regressão linear entre a severidade real e a estimada. Linhas tracejadas representam a situação ideal em que a severidade estimada é igual à real 

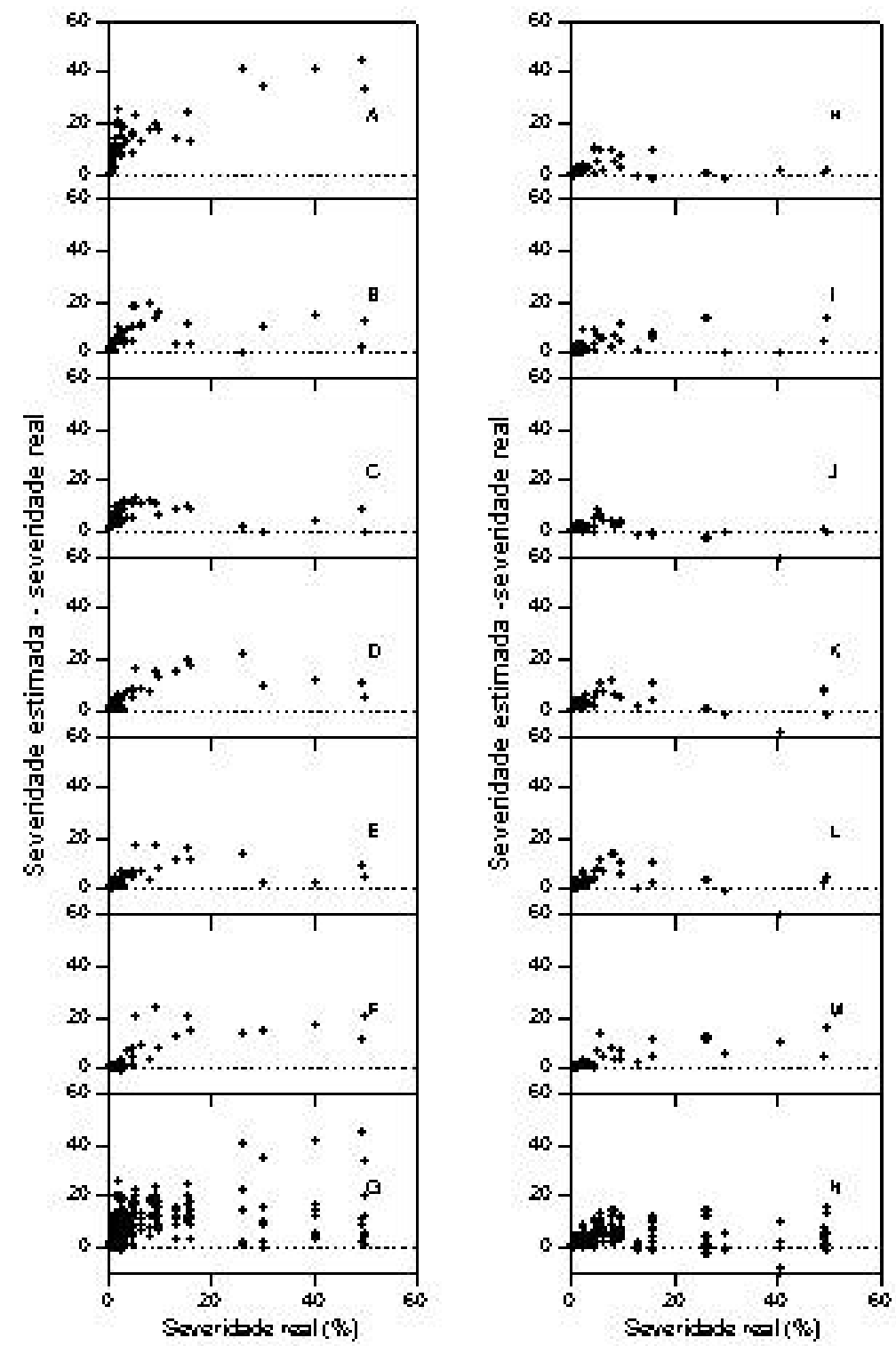

Figura 4 - Resíduos (•) das análises de regressão linear entre severidade real e severidades estimadas sem (A-G) e com $(\mathrm{H}-\mathrm{N})$ o auxílio de escala diagramática para mancha preta, por seis avaliadores e pelo conjunto dos mesmos: avaliador $1(\mathrm{~A}, \mathrm{H}), 2(\mathrm{~B}, \mathrm{I}), 3(\mathrm{C}, \mathrm{J}), 4(\mathrm{D}, \mathrm{K}), 5(\mathrm{E}, \mathrm{L})$ e $6(\mathrm{~F}, \mathrm{M})$ e para o conjunto $(\mathrm{G}, \mathrm{N})$ 
A média geral das estimativas de severidade da doença de todos os avaliadores ficou em 14,6 quando estes não utilizaram a escala e 9,9, quando utilizaram a escala diagramática. A média geral dos valores reais de severidade dos frutos fotografados foi de 7,4. Portanto, a utilização da escala fez com que os avaliadores estimassem a severidade com maior precisão. O desvio padrão dos valores estimados por todos avaliadores quando não utilizaram a escala foi de 3,45. Após a utilização da escala esse valor foi de 0,82 . Essa menor variabilidade das estimativas com o uso da escala reforça a reprodutibilidade das estimativas de severidade da doença quando utilizou-se a escala diagramática. Isso corrobora com a opinião de Nutter et al. (1998), que afirmam que a precisão e a acurácia das estimativas da severidade aumentam quando a avaliação é realizada com escalas diagramáticas, em comparação com avaliações realizadas sem o auxílio dessas ferramentas.

\subsection{Conclusões}

A utilização da escala diagramática para mancha preta dos citros, com seis níveis para os sintomas do tipo mancha dura e falsa melanose, permitiu quantificar os sintomas da doença em frutos de maneira acurada e precisa. Esses resultados sugerem que o seu uso em estudos epidemiológicos poderá proporcionar informações mais realistas a respeito do patossistema Guignardia citricarpa - citros, assim como, melhores avaliações de diferentes estratégias de controle da mancha preta dos citros. 


\section{RESISTÊNCIA À MANCHA PRETA DOS CITROS AVALIADA POR CURVAS DE PROGRESSO DA DOENÇA}

\section{Resumo}

A mancha preta dos citros (Guignardia citricarpa) vem causando sérios prejuízos à citricultura paulista. O parque citrícola está alicerçado em praticamente quatro variedades de copa de laranja doce: 'Hamlin', 'Pera', 'Valência' e 'Natal'. A literatura cita as variedades tardias ('Valência' e 'Natal') como as mais suscetíveis, em razão da elevada severidade da doença nos frutos dessas variedades por ocasião da colheita, mas não há informações sobre o progresso temporal da doença no campo. A resistência das variedades 'Hamlin' (precoce), 'Pera' (meia estação) e 'Valência' (tardia) à mancha preta dos citros foi avaliada em pomar comercial, sob infecção natural. Avaliou-se a severidade e a incidência da doença em 100 frutos de 100 plantas de cada variedade, a cada 15 dias, desde a primeira observação dos sintomas no campo até o momento da colheita. $\mathrm{O}$ modelo monomolecular foi ajustado às curvas de progresso da incidência $\mathrm{e}$ da severidade da doença para as três variedades. As três variedades apresentaram a mesma taxa de progresso da doença ( $r$. Concluiu-se que as variedades 'Hamlin', 'Pera' e 'Valência' possuem o mesmo nível de suscetibilidade à mancha preta dos citros. 


\section{Summary}

\section{Resistance to Citrus Black Spot by the Analyses of Disease Progress Curves}

Citrus black spot, caused by Guignardia citricarpa, is responsible for serious damages in São Paulo State citriculture. The main varieties of sweet orange in São Paulo State are 'Hamlin', 'Pera', 'Valência' and 'Natal'. Literature mention that late varieties like 'Valência' and 'Natal' are the most susceptible to citrus black spot, because the high disease severity in fruit of these varieties after harvest. Nevertheless there is no information about temporal disease progress in the field. Resistance of the sweet orange varieties 'Hamlin' (early), 'Pera' (mid-season), and 'Valência' (late), to citrus black spot was assessed in a commercial grove, under natural infection. Disease severity and disease incidence were assessed in 100 fruit of 100 plants of each variety, every 15 days, since the first appearance of symptoms in the field until the harvest. The monomolecular model was fitted to the data of the disease progress curves for the three varieties. The rate parameter $(r)$ of disease progress curve was not different for the three varieties. Varieties 'Hamlin', 'Pera' and 'Valência' present the same degree of susceptibility to the MPC.

\subsection{Introdução}

A mancha preta dos citros (MPC), cujo agente causal é o fungo Guignardia citricarpa Kiely, foi relatada pela primeira vez em pomares comerciais no Estado de São Paulo em 1992, na região de Limeira (Goes \& Feichtenberger, 1993). Os sintomas ocasionados pela doença depreciam os frutos para a comercialização no mercado interno de fruta fresca, assim como restringem as exportações (Aguilar-Vildoso et al., 2002). A MPC também causa a queda prematura dos frutos (Timmer, 1999), podendo levar a 
reduções de até $80 \%$ na produção (Klotz, 1978). Contudo, os sintomas da MPC ficam restritos ao flavedo dos frutos (Cardoso Filho, 2003), não havendo interferência em sua qualidade interna. Frutos doentes podem, portanto, ser utilizados no processamento para produção de suco (Aguilar-Vildoso et al., 2002).

A indústria paulista de suco de laranja está alicerçada num parque citrícola de aproximadamente 197 milhões de plantas, 98,2\% das quais são de apenas quatro variedades de laranjeiras: a precoce 'Hamlin' (1,7\%), a de meia estação 'Pera' $(48,5 \%)$ e as tardias 'Valência' (27,5\%) e 'Natal' (20,5\%) (FNP Consultoria \& Comércio, 2002). A MPC afeta todas as variedades de laranjeiras doces (Alcoba et al., 2000; AguilarVildoso et al., 2002) e a expressão de seus sintomas está relacionada com a época de maturação das variedades, sendo tanto maior quanto mais madura estiver o fruto (Feichtenberger, 1996). O período de latência varia entre 4 e 6 meses (Timmer, 1999). Altas temperaturas e intensa radiação solar são condições ambientais que favorecem a expressão dos sintomas (Kotzé, 1963). Com isto, alguns autores atribuem a maior intensidade da doença em variedades tardias, ao maior período de exposição de seus frutos a condições favoráveis para a expressão dos sintomas (Feichtenberger, 1996). Entretanto, outros autores atribuem a maior expressão de sintomas de mancha preta em variedades tardias à sua maior suscetibilidade (Kiely, 1948; Goes, 1998; Timmer, 1999).

A epidemiologia comparativa tem como objetivo identificar similaridades ou diferenças entre epidemias, baseada na natureza ou no comportamento da curva de progresso da doença (Campbell \& Madden, 1990). A comparação de curvas de progresso de doenças em variedades com diferentes níveis de resistência tem sido um dos objetos de estudo da epidemiologia comparativa. O ajuste de modelos e a comparação das áreas abaixo da curva de progresso da doença (Keinath \& Farnham, 1997; Silva et al., 1998) são métodos usualmente aplicados com esse objetivo, pois a curva de progresso da doença é a assinatura de uma epidemia, integrando os efeitos do patógeno, do hospedeiro e do ambiente em um único gráfico (Campbell \& Madden, 1990). Pode-se, portanto, comparar a resistência de variedades por meio da taxa de progresso da doença, desde que as plantas sejam submetidas a condições similares de clima e sob a mesma população patogênica. 
Este trabalho teve como objetivo comparar a suscetibilidade dos frutos de três variedades de laranjeiras doces com diferentes períodos de maturação, 'Hamlin' (precoce), 'Pera' (meia estação) e 'Valência' (tardia) à mancha preta dos citros, em condições naturais de infecção.

\subsection{Material e Métodos}

As curvas de progresso analisadas neste estudo foram obtidas em experimento conduzido em pomar comercial no Estado de São Paulo, com alta pressão de inóculo de mancha preta dos citros, onde foram selecionados três talhões de laranjeiras doces (Citrus sinensis (L) Osbeck): um talhão da variedade precoce 'Hamlin', com 9 anos de idade e espaçamento entre plantas de $8 \times 4 \mathrm{~m}$; um talhão da variedade de meia estação 'Pera', com 9 anos de idade e espaçamento entre plantas de 7 x 3,5 m; e um talhão da variedade tardia 'Valência', com 8 anos de idade e espaçamento entre plantas de 7,5 x 3,5 m. Em cada talhão foi marcado um bloco de 100 plantas (5 ruas de 20 plantas) onde avaliou-se, a partir da primeira constatação dos sintomas da doença (13 de março de 2001), a incidência (porcentagem de frutos sintomáticos) e a severidade (porcentagem de casca dos frutos afetada pela doença) em 100 frutos por planta, a cada 15 dias, até a sua colheita (18 de julho de 2001 para a variedade 'Hamlin' e 31 agosto de 2001 para as variedades 'Pera' e 'Valência'). Para avaliar a severidade da doença, utilizou-se escala diagramática contendo os principais sintomas observados no campo: o tipo "mancha dura" e o tipo "falsa melanose" (Spósito et al., 2003). Os modelos matemáticos mais usados em estudos epidemiológicos: monomolecular $\left(Y=b_{1} *\left(1-b_{2} * \exp (-r t)\right)\right)$, logístico $\left(Y=b_{1} /\left(1+b_{2} * \exp (-r t)\right)\right)$ e Gompertz $\left(Y=b_{1} * \exp \left(-b_{2} \exp (-r t)\right)\right)$, em que $Y$ é a incidência ou severidade da doença, $b_{1}$ representa a assíntota máxima estimada pelo modelo, $b_{2}$ é a constante de integração igual a 1-yo ( $\mathrm{y}_{0}=$ inóculo inicial), $r$ representa a taxa de progresso da doença e $t$ o tempo, foram ajustados às curvas de progresso da doença (Bergamin Filho \& Amorim, 1996), por meio de regressões não lineares, com o programa Statistica 6.0 (Tulsa, Statsoft). A escolha do melhor modelo foi feita pelo 
maior valor do coeficiente de determinação $\left(R^{2}\right)$ da regressão não-linear entre doença e tempo e pela ausência de padrão dos resíduos (Cornell \& Berger, 1987; Neter et al., 1996). As taxas de progresso da doença $(r)$ das curvas de incidência e de severidade da MPC obtidas com o modelo de melhor ajuste foram comparadas pelo teste $t$. Comparou se também pelo teste $t$ a assíntota máxima estimada $\left(b_{1}\right)$ e a constante de integração $\left(b_{2}\right)$ das três variedades, relacionando-as ao máximo de doença observada e ao início da expressão dos sintomas.

Foram determinados, também, em cada período de avaliação, o diâmetro médio e a cor da casca de 50 frutos da área de cada variedade. O cálculo da cor da casca foi feito através de método objetivo, utilizando para isto colorímetro Minolta, onde se mediu o índice de cor (IC) pela fórmula: IC $=1000 \times a / L \times b$, em que $L$ é a luminosidade, $a$ é a variação entre a cor verde e vermelha e o $b$ a variação entre a cor azul e a amarela (Mazzuz, 1996). Este índice varia de -20 a +20 ; quanto mais negativo, mais verde e quanto mais positivo, mais alaranjado está o fruto. $\mathrm{O}$ valor zero representa a cor amarela.

\subsection{Resultados e Discussão}

Um dos aspectos mais importantes na análise temporal de epidemias é a seleção de um modelo apropriado para descrever a curva de progresso da doença. Esta seleção tem como objetivo estimar parâmetros que são utilizados na análise estatística para a comparação entre curvas de progresso de doenças (Campbell \& Madden, 1990).

Os modelos matemáticos testados no ajuste das curvas de progresso da mancha preta dos citros (monomolecular, logístico e Gompertz) mostraram coeficientes de determinação $\left(R^{2}\right)$ muito similares para as três variedades avaliadas, 'Hamlin', 'Pera' e 'Valência' (Tabela 3). Não foram observados padrões nos resíduos dos modelos ajustados aos dados de severidade para quaisquer variedades, tampouco para os dados de incidência das variedades 'Hamlin' e 'Valência'. Para os dados ajustados de incidência da variedade 'Pera', o modelo monomolecular foi o único que não apresentou padrão no resíduo (Tabela 3). Devido a este resultado e por ter apresentado, na maioria das vezes, o coeficiente de determinação mais elevado, escolheutse o modelo monomolecular para a 
comparação das variedades (Tabela 3). Este modelo tem sido recomendado para o ajuste de dados de doenças com período de incubação variável (Bergamin Filho \& Amo rim, 2002), como é o caso da MPC, para a qual a incubação é mais dependente da fenologia do hospedeiro do que da época de infecção.

Tabela 3. Coeficientes de determinação $\left(R^{2}\right)$ e presença (+) ou ausência (-) de padrão no resíduo após ajuste dos modelos monomolecular $\left(Y=b_{1} \quad\left(1-b_{2} * \exp (-r t)\right)\right)$, logístico $\left(Y=b_{1} /\left(1+b_{2} * \exp (-r t)\right)\right)$ e Gompertz $\left(Y=b_{1} \exp \left(-b_{2} \exp (-r t)\right)\right)$, em que $Y$ é a incidência ou severidade da doença, $b_{1}$ representa a assíntota máxima estimada pelo modelo, $b_{2}$ é a constante de integração igual a (1-yo), em que $\mathrm{y}_{0}$ é o inóculo inicial, $r$ representa a taxa de progresso da doença e $t$, o tempo, aos dados de incidência e de severidade da mancha preta dos citros em três variedades cítricas

\begin{tabular}{cccccc}
\hline Variedade & Modelo & \multicolumn{2}{c}{ Incidência } & \multicolumn{2}{c}{ Severidade } \\
& & $R^{2}$ & Resíduo & $R^{2}$ & Resíduo \\
\hline 'Hamlin' & monomolecular & 0,87 & - & 0,71 & - \\
& logístico & 0,87 & - & 0,71 & - \\
& Gompertz & 0,88 & - & 0,71 & - \\
‘Pera' & monomolecular & 0,93 & - & 0,78 & - \\
& logístico & 0,89 & + & 0,81 & - \\
& Gompertz & 0,91 & + & 0,80 & - \\
‘Valência' & monomolecular & 0,89 & - & 0,77 & - \\
& logístico & 0,86 & - & 0,77 & - \\
& Gompertz & 0,88 & - & 0,77 & - \\
\hline
\end{tabular}

As curvas médias de progresso de incidência da MPC, produzidas pelo modelo monomolecular, foram bastante similares nas três variedades avaliadas (Figura 5A, C, E). O período de avaliação da variedade 'Hamlin' foi mais curto do que nas demais variedades em virtude do amadurecimento precoce e conseqüentemente da colheita de seus frutos. As curvas de progresso da severidade da MPC foram similares nas variedades 'Hamlin' e 'Valência' (Figura 5B, F) e a variedade 'Pera' mostrou maior severidade final que as demais (Figura 5D). Entretanto, estas diferenças não foram 
perceptíveis quando os parâmetros do modelo foram comparados pelo teste $t$. Os valores da assíntota máxima $\left(b_{1}\right)$ para as três variedades, obtidos para a severidade da doença, não diferiram entre si a $5 \%$ de probabilidade (Tabela 4). As constantes de integração $\left(b_{2}\right)$, relacionadas ao inóculo inicial da doença, obtidas para as curvas de progresso da incidência e severidade da MPC, foram significativamente maiores para a variedade 'Hamlin' (Tabela 4). A expressão dos sintomas da MPC está diretamente relacionada com o amadurecimento dos frutos (Feichtenberger, 1996). O maior valor do inóculo inicial na variedade 'Hamlin', representado por $b_{2}$, provavelmente deveuse ao fato desta variedade iniciar o amadurecimento dos frutos antes das demais variedades. No início das avaliações, os frutos da variedade 'Hamlin' apresentaram um maior diâmetro e casca com cor verde menos intensa quando comparados com os das outras variedades (Figura 6). Esse resultado, entretanto, não exprime as diferenças na suscetibilidade dessas variedades à MPC. O parâmetro que determina a suscetibilidade do hospedeiro à determinada doença é a taxa de progresso da doença ( $r$ ) (Campbell \& Madden, 1990).

Tabela 4. Assíntota máxima $\left(b_{1}\right)$, inóculo inicial $\left(b_{2}\right)$ e taxa de progresso da doença $(r)$ estimados pelo modelo monomolecular $\left(Y=b_{1}\left(1-b_{2} * \exp (-r t)\right)\right)$, para os dados de incidência e severidade em três variedades cítricas

\begin{tabular}{|c|c|c|c|c|c|c|c|c|}
\hline \multirow{3}{*}{$\begin{array}{l}\text { Variedade } \\
\text { 'Hamlin' }\end{array}$} & \multicolumn{4}{|c|}{ Incidência * } & \multicolumn{4}{|c|}{ Severidade * } \\
\hline & $b_{1}$ & $b_{2}$ & & $r$ & $b_{1}$ & $b_{2}$ & & $r$ \\
\hline & 1 & $0,13 \mathrm{a}$ & & $0,014 \mathrm{a}$ & $0,026 \mathrm{a}$ & 0,22 & $\mathrm{a}$ & $0,0096 \mathrm{a}$ \\
\hline 'Pera' & 1 & 0,02 & $\mathrm{~b}$ & $0,013 \mathrm{a}$ & $0,038 \mathrm{a}$ & 0,08 & $\mathrm{~b}$ & $0,0107 \mathrm{a}$ \\
\hline 'Valência' & 1 & 0,00 & $\mathrm{~b}$ & $0,015 \mathrm{a}$ & $0,029 \mathrm{a}$ & 0,04 & & $0,0097 \mathrm{a}$ \\
\hline
\end{tabular}




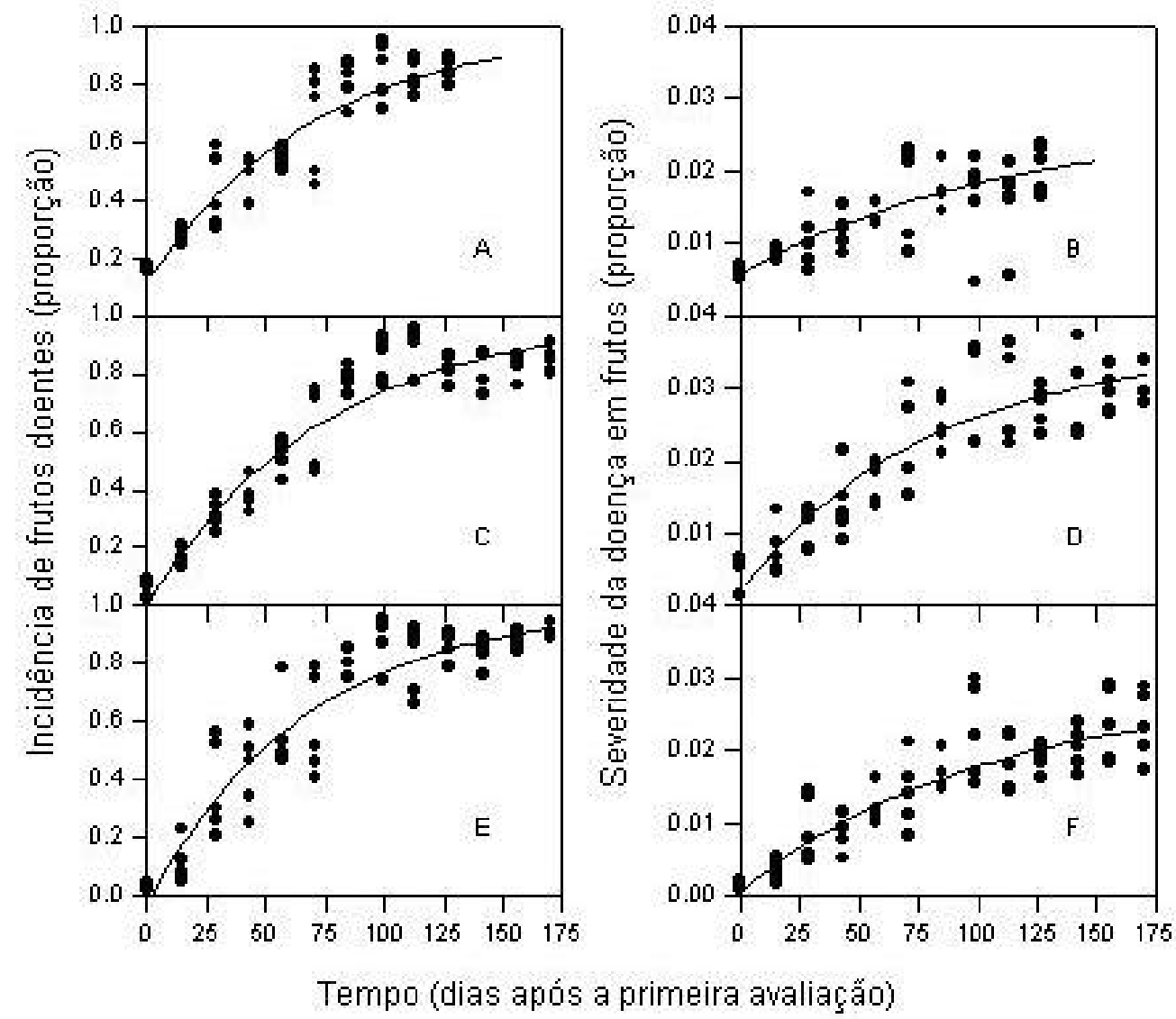

Figura 5 - Curvas de progresso da incidência (A, C, E) e da severidade (B, D, F) de mancha preta dos citros nas variedades 'Hamlin' (A-B), 'Pera' (C-D) e 'Valência' (E-F) avaliadas a cada 15 dias a partir de 13 de março de 2001 até o período da respectiva colheita. Pontos representam dados médios de 20 plantas de cada repetição obtidos por avaliação e linhas representam o ajuste do modelo monomolecular

$\mathrm{Na}$ epidemiologia comparativa, o parâmetro utilizado para diferenciar a suscetibilidade das variedades éa taxa de progresso da doença. A taxa de progresso tanto da incidência quanto da severidade da MPC para as variedades 'Hamlin', 'Pera' e 'Valência' não diferiram entre si a $5 \%$ de probabilidade pelo teste $t$ (Tabela 9). Esse 
resultado indica que a doença cresceu na mesma velocidade nas três variedades e que, portanto, as três variedades apresentaram um mesmo grau de suscetibilidade para a mancha preta dos citros.
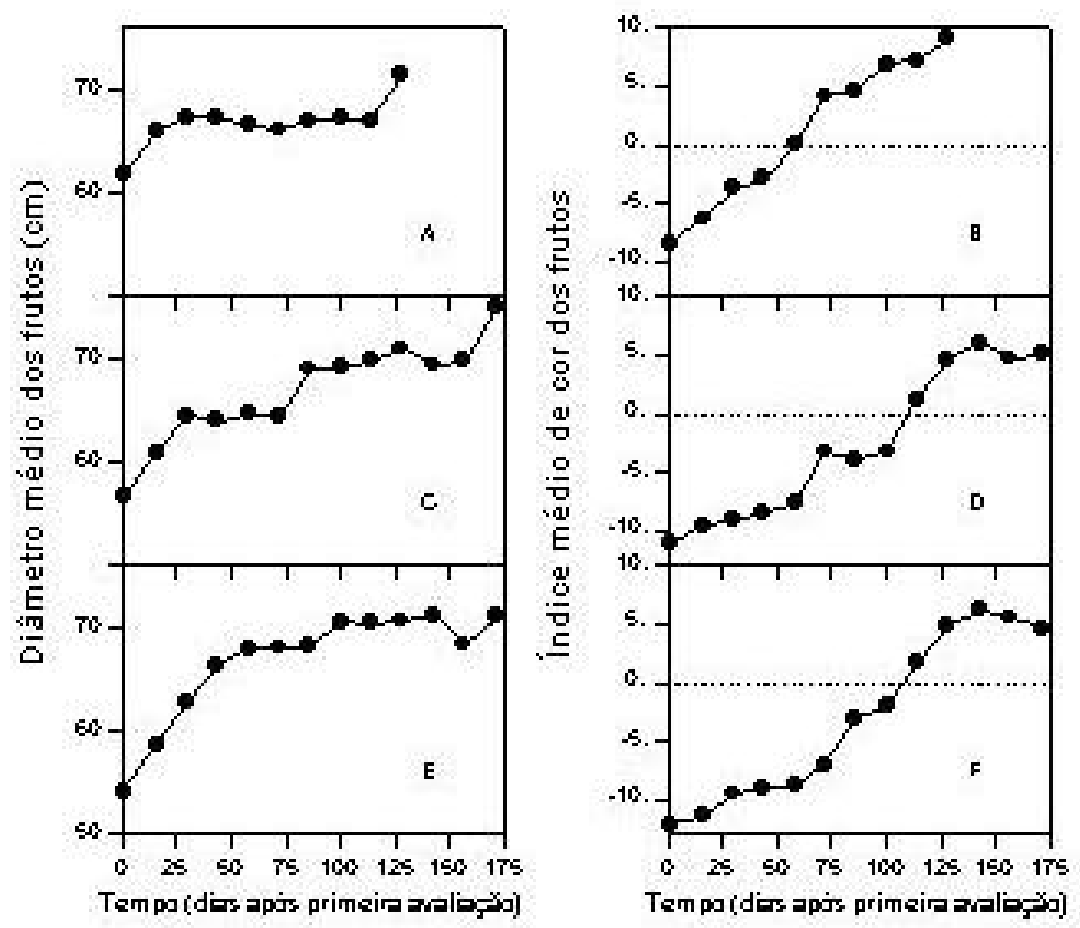

Figura 6 - Curvas médias de variação do diâmetro (A, C, E) e do índice de cor (B, D, F) dos frutos das variedades 'Hamlin' (A-B), 'Pera' (C-D) e 'Valência' (E-F) avaliados a cada 15 dias, a partir de 13 de maio de 2001 até o período da respectiva colheita

Os frutos da variedade 'Hamlin' alcançaram seu tamanho final e o amadurecimento externo (diâmetro médio dos frutos e índice de cor da casca, respectivamente) antes das variedades 'Pera' e 'Valência', as quais mostraram-se similares ao longo do tempo (Figura 6). Como o fungo Guignardia citricarpa após infectar os futos cítricos permanece na região subcuticular na forma de micélio 
quiescente (Feichtenberger, 1996) e o sintoma da doença restringe-se à região do flavedo (Cardoso Filho, 2003), correlacionourse o índice de cor da casca com a severidade e com a incidência da mancha preta para as variedades de laranja doce 'Hamlin', 'Pera' e 'Valência' (Figura 7). A correlação foi alta para as três variedades, entretanto o padrão observado para a 'Hamlin' diferiou das demais variedades (Tabela 5). Os sintomas da doença iniciaram-se com os frutos ainda verdes e intensificaram-se com a mudança da coloração da casca. Para as variedades 'Pera' e 'Valência', o incremento da doença deut se até os frutos alcançarem um índice de cor entre -4 e -2 (mudança de cor do verde para o amarelo), estabilizando-se acima destes valores. $\mathrm{Na}$ variedade 'Hamlin' o incremento da doença foi quase linear desde os frutos totalmente verdes (-8), até a coloração laranja (+8), época de sua colheita (Figura 7). Nas variedades 'Pera' e 'Valência' a melhor época para a avaliação dos experimentos, na qual a incidência e a severidade de MPC nos frutos são máximas, é quando a cor da casca dos frutos atingem o valor zero. Neste caso a avaliação pode ser efetuada antes do período de colheita. Para a 'Hamlin' a incidência e a severidade máximas só são obtidas na época de colheita devido ao incremento contínuo da doença com o incremento do índice de cor dos frutos (Figura 7).

Tabela 5. Parâmetros $a, b$ e $c$ das equações de segundo grau $\left(y=a x^{2}+b x+c\right.$, onde $y$ representa a intensidade da doença e $x$, o índice médio de cor dos frutos) e coeficientes de determinação $\left(R^{2}\right)$ dos modelos das curvas médias de variação da incidência e severidade de mancha preta em relação ao índice de cor da casca dos frutos nas variedades 'Hamlin', 'Pera' e 'Valência'

\begin{tabular}{lcccccccc}
\hline Variedade & \multicolumn{4}{c}{ Incidência } & \multicolumn{4}{c}{ Severidade } \\
& $a$ & $b$ & $c$ & $R^{2}$ & $a$ & $b$ & $c$ & $R^{\swarrow}$ \\
\hline 'Hamlin' & $-0,09$ & 4,10 & 57,79 & 0,98 & $-0,01$ & 0,08 & 1,41 & 0,99 \\
'Pera' & $-0,48$ & 1,82 & 86,14 & 0,93 & $-0,02$ & 0,06 & 3,04 & 0,93 \\
'Valência' & $-0,43$ & 1,54 & 90,06 & 0,98 & $-0,01$ & 0,05 & 2,09 & 0,94 \\
\hline
\end{tabular}



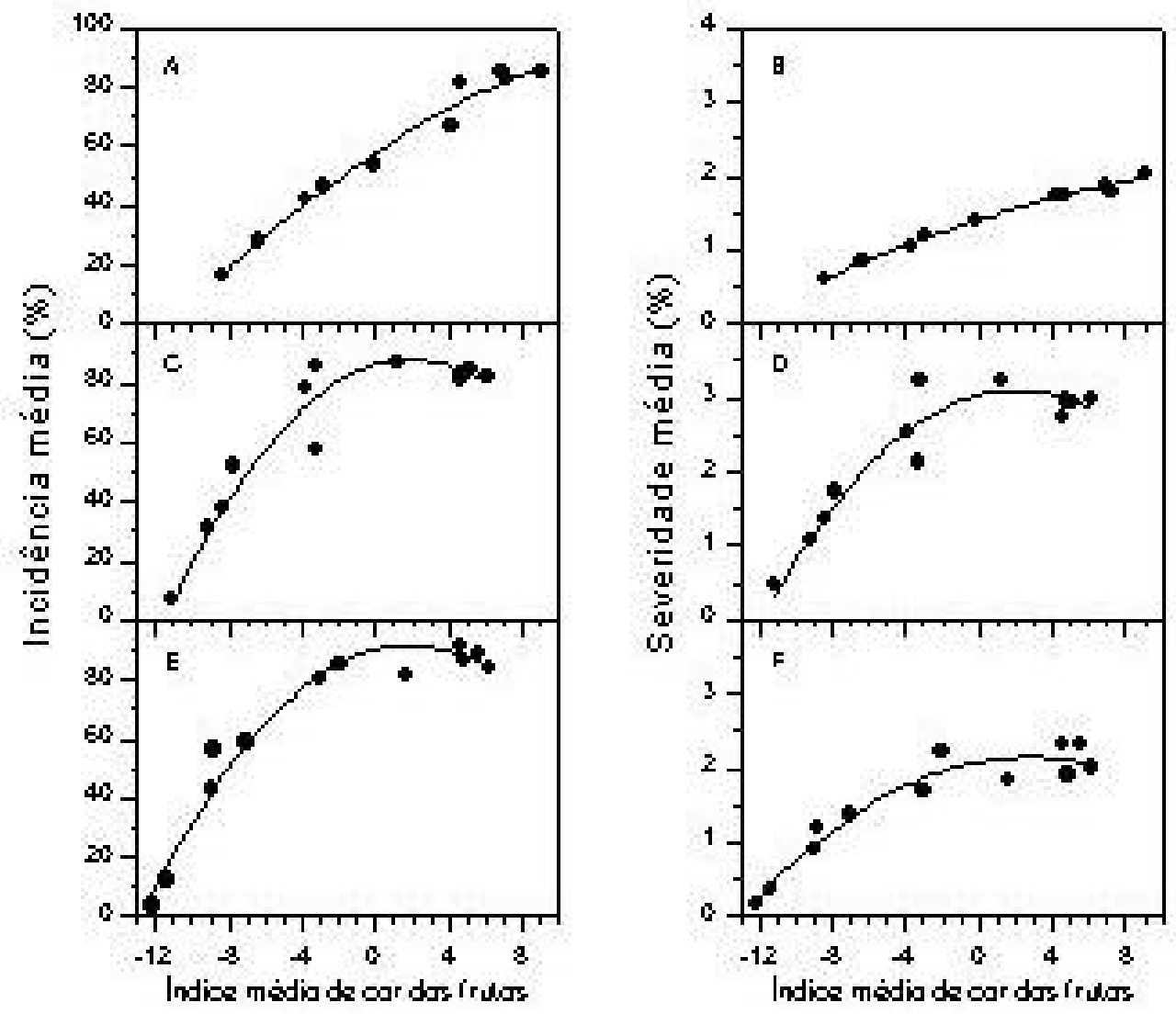

Figura 7 - Curvas médias de variação da incidência e severidade de mancha preta em relação ao índice de cor em frutos das variedades 'Hamlin' (A-B), 'Pera' (CD) e 'Valência' (E-F)

Os frutos cítricos possuem dois processos de desenvolvimento, resultando em sua maturação, um processo interno onde ocorre um aumento gradual de sólidos solúveis totais do suco junto com uma diminuição de sua acidez total, e um processo externo em que ocorre a degradação da clorofila, por temperaturas altas, e a síntese de carotenos, por temperaturas baixas (Davies \& Albrigo, 1999). Esses dois processos são independentes e ocorrem conjuntamente, entretanto ambos são dependentes do ambiente e dos genótipos da copa e do porta-enxerto utilizados. 


\subsection{Conclusões}

O mesmo grau de suscetibilidade à mancha preta dos citros entre as variedades 'Hamlin', 'Pera' e 'Valência', obtidos pela comparação das taxas de progresso da doença $(r)$, assim como as correlações encontradas entre o índice de cor e a severidade ou a incidência da doença obtidos neste experimento, exprimem a relação existente entre o processo de maturação dos frutos cítricos, dependente das condições ambientais, com a intensidade dos sintomas da doença. 


\section{PADRÃO ESPACIAL DE LARANJEIRAS COM MANCHA PRETA DOS CITROS}

\section{Resumo}

O fungo Guignardia citricarpa Kiely [Phyllosticta citricarpa (McAlp.) van der Aa.], agente causal da mancha preta dos citros (MPC), apresenta dois tipos de inóculo: ascósporos, dispersos a curtas e longas distâncias pela ação do vento, e conídios, dispersos a curtas distâncias pela ação da água. Quando a dispersão a curtas distâncias predomina, a doença manifesta-se em agregados. Contrariamente, quando a doença é resultante de esporos dispersos a longas distâncias da fonte, as plantas doentes são aleatoriamente distribúdas no campo, principalmente no início da epidemia, quando a incidência é baixa. A distribuição espacial da MPC foi avaliada pelo índice de dispersão (D) e pela função K de Ripley em quatro áreas, com os objetivos de avaliar a importância da dispersão a curtas e longas distâncias e de desenvolver um programa amostral para a doença. As plantas doentes mostraram agregação, pelos dois métodos de análise ( $D$ e K), independentemente da incidência da mancha preta, indicando elevada importância da dispersão do inóculo a curtas distâncias. Para a amostragem de MPC em pomares médios de 2200 plantas, 285 plantas mostraram-se suficientes para indicar incidências superiores a $15 \%$. Nesse caso, as plantas a serem amostradas devem ser escolhidas ao acaso e a sequiência no campo deve ser aleatória cobrindo toda a extensão da área. Para incidências inferiores a $15 \%$ de plantas doentes, o número de plantas a serem amostradas aumenta exponencialmente com o decréscimo da incidência. 


\section{Summary}

\section{Spatial Pattern of Orange Plants with Citrus Black Spot}

The fungus Guignardia citricarpa Kiely Phyllosticta citricarpa (McAlp.) van der Aa.], the causal agent of citrus black spot (CBS), produce two types of inocula: The ascospores disseminated to short and long distances by wind and conidia disseminated to short distance by water. Short distance dispersion result in diseased aggregation, while long distance dispersion result in random field distribution of the symptomatic plants, mainly in the beginning of the epidemy, when the incidence is low. The spatial distribution of CBS in four areas was evaluated by dispersion index $(D)$ and Ripley K function, to study the importance of short and long distance dispersion and development of a sampling program for the disease. The $D$ and $\mathrm{K}$ method detected aggregation in diseased plants, independently of the CBS incidence, suggesting high importance of short distance dispersion. In 2200 plants orchards, the CBS incidence, superior to 15\%, may be randomly sampled with 285 plants that must cover the whole orchard. The number of sampled plants increase exponentially to decrease of disease incidence.

\subsection{Introdução}

O fungo Guignardia citricarpa Kiely Phyllosticta citricarpa (McAlp.) van der Aa.], agente causal da mancha preta dos citros (MPC), produz dois tipos de esporos durante a fase epidêmica da doença. Em sua fase perfeita, o patógeno produz ascósporos de Guignardia citricarpa em pseudotécios formados em folhas de citros em decomposição, que são dispersos a curtas e longas distâncias pela ação do vento. Em sua fase imperfeita, são produzidos conídios de Phyllosticta citricarpa em picnídios em frutos e ramos, que são dispersos a curtas distâncias pela ação da água (Timmer, 1999). 
Patógenos dispersos principalmente pelo vento podem atingir longas distâncias dentro de um curto período de tempo (Aylor, 1990; Pedgley, 1986) resultando, geralmente, em padrões espaciais ao acaso de plantas doentes (Bergamin Filho et al., 2002). Neste caso, a probabilidade de um esporo veiculado pelo ar ser depositado sobre uma planta é igual para todas as plantas, não sendo, portanto, influenciada pela distância até a fonte de inóculo (Bergamin et al., 2002). Patógenos veiculados por respingos de chuva dispersam-se lentamente ao redor dos focos primários (Madden, 1992; Huber et al., 1993) resultando, geralmente, em padrões agregados de plantas doentes (Bergamin Filho et al., 2002). Neste caso, a probabilidade de uma planta ser infectada é maior para aquelas plantas situadas perto da fonte de inóculo (Bergamin Filho et al., 2002).

Entretanto, o padrão espacial de uma doença, observado pelo arranjamento espacial de plantas ou órgãos de plantas doentes, além de depender dos mecanismos de dispersão do patógeno, depende também da arquitetura das plantas hospedeiras assim como do arranjo destas plantas no campo (Gilligan, 1982).

O conhecimento do padrão espacial de uma doença fornece subsídios importantes para o entendimento de uma epidemia (Campbell \& Madden, 1990), auxiliando no desenvolvimento de programas de amostragem, assim como para o manejo da doença (Campbell \& Madden, 1990).

O presente trabalho teve como objetivo caracterizar os padrões espaciais de distribuição da mancha preta em pomares comerciais, com base nas plantas com frutos sintomáticos, quantificar o nível de dependência entre plantas sintomáticas e determinar o número de plantas amostrais necessárias para estimativa da incidência da doença.

\subsection{Material e Métodos}

Os levantamentos foram conduzidos em quatro áreas com diferentes intensidades de mancha preta dos citros (MPC). Na área I o levantamento foi realizado em um talhão com 2533 plantas de laranjeira doce 'Natal' (Citrus sinensis Osbeck) enxertadas em tangerineira 'Cleópatra' (Citrus reshni Hort.), com espaçamento entre plantas de 9 m x 6 m, plantadas no ano de 1984, totalizando uma área amostral de 15,2 hectares. Na área II, 
avalioutse a doença em um talhão de 1241 plantas de laranjeira doce 'Valência' enxertadas em limoeiro 'Cravo' (Citrus limonia Osbeck), espaçadas de 7 m x 4 m e plantadas em 1993, totalizando uma área amostral de 3,5 hectares. Na área III, o monitoramento da MPC foi feito em um talhão de 990 plantas de laranjeira doce 'Valência' enxertadas em limoeiro 'Cravo', com espaçamento entre plantas de 7,5 m x 5,5 m, plantadas no ano de 1984, totalizando uma área amostral de 4,1 hectares. Na área IV, o levantamento foi feito em um talhão com 3026 plantas de laranjeira doce 'Natal' enxertadas em tangerineira 'Cleópatra', com espaçamento de $8 \mathrm{~m}$ x $5 \mathrm{~m}$, plantadas no ano de 1990, totalizando uma área amostral de 12,1 hectares. Todas as áreas foram aerofotografadas e georeferenciadas, utilizando-se o sistema de posicionamento global (GPS).

$\mathrm{Na}$ área I, todas as plantas do talhão foram avaliadas nos anos de 1999, $2000 \mathrm{e}$ 2001. Nas áreas II, III e IV, todas as plantas dos talhões foram avaliadas no ano de 2002. Avaliourse a incidência de plantas com mancha preta (presença ou ausência de frutos sintomáticos) no período de pré-colheita. Os resultados gerados foram analisados para a interpretação dos padrões espaciais de plantas sintomáticas pelo índice de dispersão binomial $(D)$ e por análise de padrões pontuais pela função $\mathrm{K}$ de Ripley. Esses métodos tiveram como finalidade indicar o padrão de agregação ou aleatoriedade de plantas sintomáticas nas áreas avaliadas.

Nas análises de padrão de distribuição pelo índice de dispersão binomial $D$, as áreas amostrais foram divididas em quadrats de 2x2, 3x3, 4x4, 5x5, 6x6, 7x7, 8x8, 9x9 e 10x10 plantas. Para cada caso a incidência $(p)$ de plantas doentes, definida como a proporção de plantas com MPC no talhão, foi calculada pela equação $p=\Sigma X_{i} / \mathrm{nN}$, em que $X_{i}$ é o número de plantas com frutos sintomáticos de MPC no iésimo quadrat, n é o número de plantas por quadrat e N é o número total de quadrats (Madden \& Hughes, 1995). A partir destes dados calculou-se o $D$ em função da variância binomial, Vbin $=$ $p(1-p) / \mathrm{n}$ e da variância observada $V_{o b s}=\sum_{i=1}^{N}\left(x_{i}-n p\right)^{2} / n^{2}(N-1)$, de acordo com Hughes et al. (1996). O $D$ foi estimado pela equação $D=\mathrm{V}_{\text {obs }} / \mathrm{V}_{\text {bin }}$ (Gottwald et al., 1996). Ao valor de $D$ para cada avaliação foi aplicado o teste do $\chi^{2}$ (chi-quadrado) a $5 \%$ de 
significância. Valores de $D$ iguais a 1 indicam que as plantas com MPC estão distribuídas aleatoriamente na área (ao acaso). Valores de $D$ significativamente maiores que 1 indicam que as plantas com frutos com sintomas estão agregadas na área (Madden \& Hughes, 1995).

A análise de padrões pontuais, feita pela função $\mathrm{K}(h)$ de Ripley, verifica a densidade de plantas doentes em cada área, considerando a variância de todas as distâncias radiais $(h)$ possíveis a partir de todas as plantas sintomáticas. A Função $\mathrm{K}(h)$ é definida por $\mathrm{K}(h)=E \ddot{e}^{-1}$, em que ë é a densidade dos eventos ou o número médio de plantas sintomáticas por unidade de área, e $E$ é o número de plantas sintomáticas dentro de uma unidade de área definida pela distância $h$ a partir de uma planta sintomática arbitrária. A Função K(h) é estimada pela fórmula (Ripley, 1981):

$$
K(h)=\frac{\lambda^{-1} \sum_{i=1}^{n} \sum_{j=1}^{n} I_{h}\left(E_{i}, E_{j}\right)}{n} \quad \text { para } i \quad j \text { e } t>0
$$

No caso de um processo aleatório, sem dependência espacial de plantas doentes, tem-se $\mathrm{K}(h)=ð h^{2}$. Sob agregação espera-se que $\mathrm{K}(h)>ð h^{2}$ e para regularidade $\mathrm{K}(h)<ð h^{2}$.

A normalização da Função K facilita a interpretação gráfica e pode ser obtida por (Kenkel, 1988):

$$
L(h)=\sqrt{\frac{K(h)}{\pi h^{2}}}-h
$$

onde plota-se os valores de $\mathrm{L}(h)$ contra a distância $(h)$, facilitando a visualização do fenômeno. Valores positivos indicam atração espacial, ou seja, agregação. Valores negativos indicam repulsão ou regularidade. Os valores dentro do envelope de confiança representam aleatoriedade (Kenke1, 1988).

Para a obtenção de um padrão de amostragem para MPC, utilizou-se os dados dos seis diferentes mapas gerados neste experimento nas áreas I, II, III e IV. Entre os métodos aplicados para amostragem em epidemiologia de doenças de plantas utilizourse a equação em que a confiabilidade é definida pelo coeficiente de variabilidade (Campbell \& Maden, 1990): 


$$
n=\frac{s^{2}}{x^{2} C^{2}}
$$

em que, $n$ é o número de amostras necessárias para estimar plantas doentes em uma área, $s^{2}$ é a variância das plantas doentes em uma área, $x$ é a média de plantas doentes em uma área e $C^{2}$, o coeficiente de variação das plantas doentes em uma área.

Nos casos de aleatoriedade, agregação ou regularidade na distribuição espacial da doença, a equação é ajustada ao padrão de distribuição podendo ser Poisson, binomial negativa ou binomial positiva, respectivamente (Campbell \& Madden, 1990).

\subsection{Resultados e Discussão}

O relacionamento de análises de distribuição espacial, aplicados na indicação de comportamentos sistemáticos, como agregação, regularidade ou aleatoriedade de plantas doentes, com análises de padrões pontuais, aplicados na localização da doença no espaço e quantificação do padrão observado, tem sido objeto de estudos em outros patossistemas (Charest et al., 2002).

As áreas amostrais apresentaram diferentes níveis de incidência de plantas com frutos sintomáticos. Na área I, nos três anos avaliados, 1999, 2000 e 2001 as incidências de plantas com MPC foram de 10,7\%, 22,7\% e 84,9\%, respectivamente (Figura 8). Nas áreas II, III e IV, para o ano de 2002, as incidências de plantas doentes foram de 5,9\%, $17,5 \%$ e $0,6 \%$, respectivamente (Figura 9).

No cálculo do índice de dispersão $(D)$, onde utilizourse 5\% de significância, a área I apresentou para os anos de 1999, 2000 e 2001, respectivamente, 2, 6 e 8 diferentes tamanhos de quadrats cujos valores foram estatisticamente superiores a 1. O quadrat com 49 plantas (7x7) foi o único que apresentou agregação nos três anos avaliados e em duas das três avaliações feitas nesta área foi o que apresentou o maior índice de dispersão (Tabela 6). Na área II, avaliada em 2002, 3 dos 9 tamanhos de quadrats testados, apresentaram valores estatisticamente superiores a 1, sendo o quadrat de 6x6 plantas o que apresentou maior índice de dispersão, 1,6, indicando um padrão espacial de agregação na área (Tabela 7). Na área III, todos os 9 tamanhos de quadrats testados 
apresentaram valores estatisticamente superiores a 1, com índices de dispersão crescentes com o aumento do tamanho de quadrats, indicando um padrão espacial de agregação na área em todas as situações. Na área IV, avaliada em 2002, 8 dos 9 tamanhos de quadrats testados, apresentaram valores estatisticamente superiores a 1. O quadrat de 7x7 plantas foi o que apresentou maior índice de dispersão (Tabela 7). Portanto, houve agregação de plantas sintomáticas no campo dentro de quadrats de 36 a 49 plantas.

As estimativas de $\mathrm{K}(h)$ e dos envelopes de confiança para a incidência de plantas doentes nas áreas avaliadas, foram obtidos pelo pacote splancs (Rowlingson \& Diggle, 1993), do programa R (Figuras 8 e 9). Pelas análises da área I, para os três anos, os valores de $\mathrm{L}(h)$ encontraram-se acima do envelope de confiança, mostrando um padrão de agregação. No ano de 2001 o comportamento agregado foi menos intenso do que o observado nos anos anteriores. Isto se justifica pelo fato de em 2001, 84,9\% das plantas estarem com frutos sintomáticos, o que dificulta a observação de agregação na área. Os picos negativos e dentro do envelope observados para distâncias menores que 10 metros são devidos ao espaçamento da cultura (Figura 8). Na área II, a agregação ocorreu em um raio entre 25 e 35 metros, enquanto que na área III, houve agregação de plantas doentes contidas em um raio de até 25 metros, doentes (Figura 9). Na área IV, por apresentar uma incidência de plantas doentes muito baixa $(0,6 \%)$, não foi possível a obtenção das estimativas de $\mathrm{K}(h)$.

A utilização do índice de dispersão binomial $(D)$ e da função K de Ripley, para a análise do padrão espacial da doença, permitiram comparar dois métodos diferentes usualmente utilizados nesse tipo de estudo. Enquanto o índice de dispersão binomial utiliza a variância dos dados em sub-áreas pré-estabelecidas dentro de uma área amostral (quadrats), a função K de Ripley utiliza a variância dos dados em diferentes raios a partir de cada planta sintomática (evento) existente dentro da área amostral. 

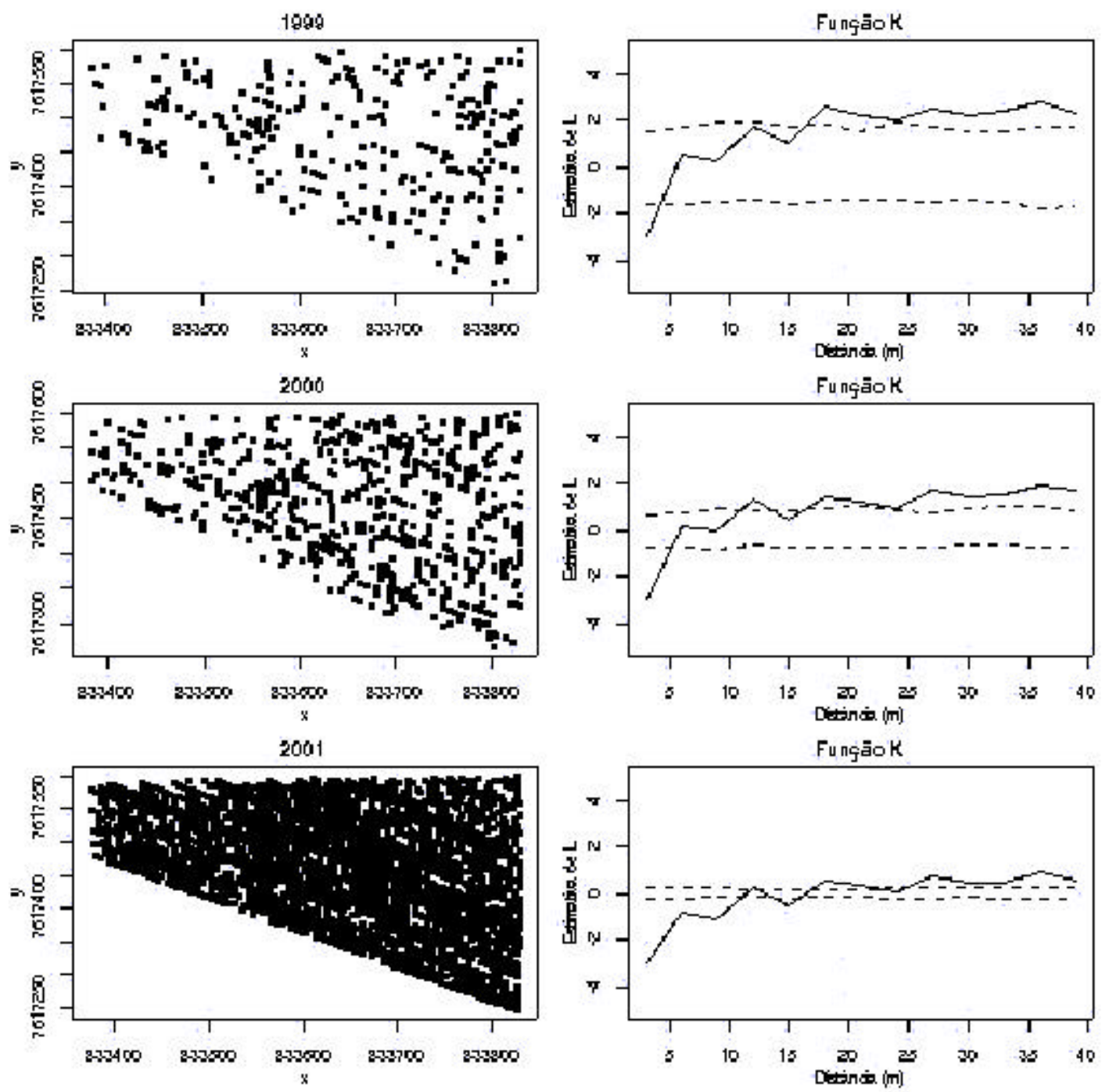

Figura 8 - Distribuição de plantas com frutos sintomáticos de mancha preta dos citros e o ajuste da função $K$ de Ripley (— ) na área I, para os anos 1999, 2000 e 2001. Valores acima do envelope de confiança (---) exprime agregação 
A

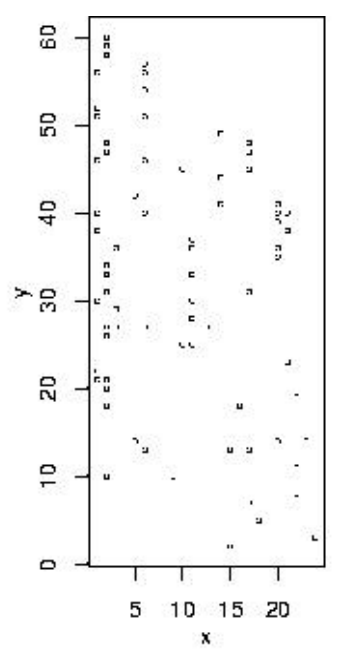

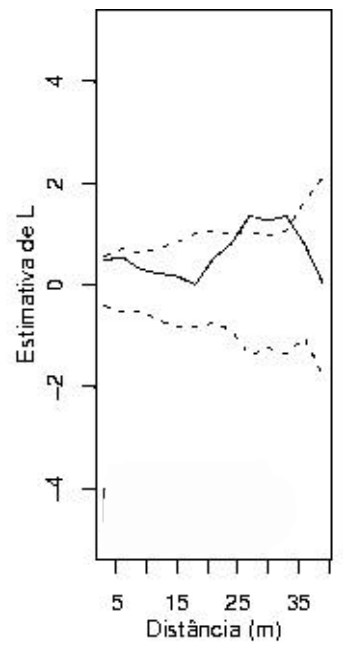

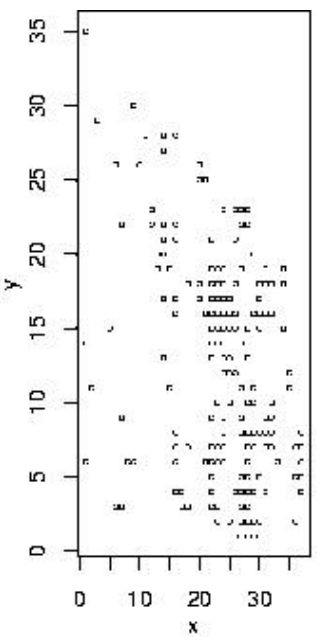

B

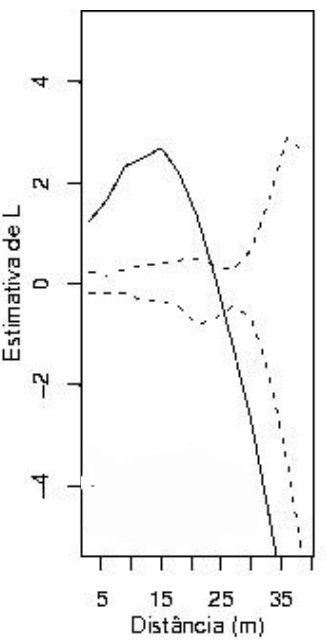

C
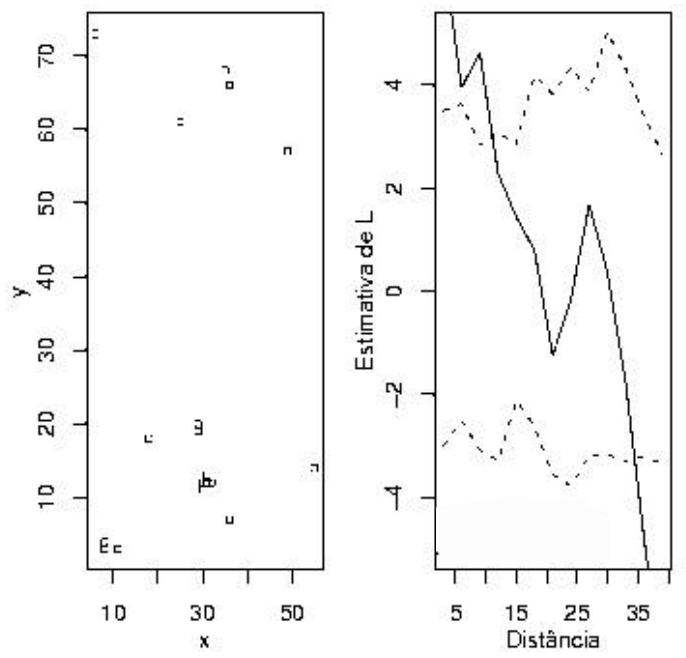

Figura 9 - Distribuição de plantas com frutos sintomáticos com mancha preta dos citros e o ajuste da função $K$ de Ripley (- ) nas áreas II (A), III (B) e IV (C). Valores acima do envelope de confiança (---) exprime agregação 
Tabela 6. Incidência $(P)$ e Índice de Dispersão $(D)$, de plantas com frutos sintomáticos com MPC, em pomar comercial de laranjeira doce 'Natal', na área I, para as diferentes combinações de quadrats nos 3 anos avaliados (1999, 2000, 2001)

\begin{tabular}{|c|c|c|c|c|c|c|c|c|c|c|}
\hline \multirow[t]{3}{*}{ Quadrat } & \multirow[t]{3}{*}{$N q^{2}$} & \multicolumn{9}{|c|}{ Area I } \\
\hline & & \multicolumn{3}{|c|}{1999} & \multicolumn{3}{|c|}{2000} & \multicolumn{3}{|c|}{2001} \\
\hline & & $P$ & $D^{\mathrm{y}}$ & & $P$ & $D^{\mathrm{y}}$ & & $P$ & $D^{\mathrm{y}}$ & \\
\hline $2 \times 2$ & 360 & 10,5 & 1,1 & ns & 23,2 & 1,3 & $*$ & 86,3 & 1,0 & $\overline{\mathrm{ns}}$ \\
\hline $3 \times 3$ & 144 & 10,7 & 1,1 & ns & 24,3 & 1,7 & $*$ & 86,3 & 1,2 & $*$ \\
\hline $4 \times 4$ & 90 & 10,5 & 1,2 & ns & 23,2 & 1,6 & $*$ & 86,3 & 1,4 & $*$ \\
\hline $5 \times 5$ & 56 & 10,4 & 1,1 & ns & 23,2 & 1,7 & $*$ & 86,4 & 1,4 & $*$ \\
\hline $6 \times 6$ & 36 & 10,7 & 1,4 & ns & 24,3 & 1,4 & ns & 86,3 & 1,6 & $*$ \\
\hline $7 \times 7$ & 20 & 10,8 & 2,2 & $*$ & 24,5 & 1,8 & $*$ & 87,4 & 1,6 & $*$ \\
\hline $8 \times 8$ & 18 & 11,1 & 1,4 & ns & 24,3 & 1,6 & $*$ & 86,1 & 1,8 & $*$ \\
\hline $9 \times 9$ & 16 & 10,7 & 0,9 & ns & 24,3 & 1,5 & ns & 86,3 & 2,2 & $*$ \\
\hline $10 \times 10$ & 14 & 10,4 & 1,7 & $*$ & 23,2 & 0,9 & ns & 86,4 & 1,8 & $*$ \\
\hline
\end{tabular}

Os dados obtidos tanto pelo índice de dispersão binomial $(D)$ quanto pela função $\mathrm{K}$ de Ripley, mostraram um padrão de agregação de plantas com frutos sintomáticos independentemente da incidência de plantas doentes. Este resultado denota a existência de focos, mais ou menos agregados, formados por plantas sintomáticas. Trabalhos desenvolvidos com a sarna da macieira, cujo patossistema assemelha-se ao da MPC, mostraram que a dispersão da maioria dos ascósporos de Venturia inaequalis, dentro do pomar, ocorre num raio de 20 metros (Hsiang et al., 2000) e que, a quantidade de ascósporos disseminados reduz em 99\% a 6 metros de distância da fonte (Kaplan, 1986). 
Tabela 7. Incidência $(P)$ e Índice de Dispersão $(D)$, de plantas com frutos sintomáticos com mancha preta, em pomares comerciais de laranjeiras doces 'Valência' (áreas II e III) e 'Natal' (área IV), para as diferentes combinações de quadrats avaliado no ano de 2002

\begin{tabular}{|c|c|c|c|c|c|c|c|c|c|c|c|c|}
\hline \multirow[t]{2}{*}{ Quadrat } & \multicolumn{4}{|c|}{ Área II } & \multicolumn{4}{|c|}{ Ārea III } & \multicolumn{4}{|c|}{ Área IV } \\
\hline & $\mathrm{Nq}^{\mathrm{z}}$ & $P$ & $D^{\mathrm{y}}$ & & $\mathrm{Nq}^{\mathrm{z}}$ & $P$ & $D^{\mathrm{y}}$ & & $\mathrm{Nq}^{\mathrm{z}}$ & $P$ & $D^{\mathrm{y}}$ & \\
\hline $2 \times 2$ & 240 & 5,6 & 1,2 & $*$ & 184 & 19,6 & 1,8 & $*$ & 588 & 0,7 & 1,4 & * \\
\hline $3 \times 3$ & 96 & 5,6 & 1,3 & $*$ & 77 & 19,6 & 3,2 & $*$ & 266 & 0,7 & 1,3 & $*$ \\
\hline $4 \times 4$ & 60 & 5,6 & 1,3 & ns & 40 & 19,6 & 4,2 & $*$ & 140 & 0,7 & 1,6 & $*$ \\
\hline $5 \times 5$ & 36 & 5,6 & 1,0 & ns & 28 & 19,6 & 5,9 & $*$ & 88 & 0,7 & 1,5 & $*$ \\
\hline $6 x 6$ & 24 & 5,6 & 1,6 & $*$ & 15 & 19,6 & 7,7 & $*$ & 63 & 0,7 & 1,6 & $*$ \\
\hline $7 \times 7$ & 12 & 5,6 & 1,6 & ns & 15 & 19,6 & 9,3 & $*$ & 48 & 0,7 & 2,0 & $*$ \\
\hline $8 x 8$ & 12 & 5,6 & 1,5 & ns & 8 & 19,6 & 10,2 & $*$ & 35 & 0,7 & 1,7 & $*$ \\
\hline $9 \times 9$ & 10 & 5,6 & 1,2 & $\mathrm{~ns}$ & 6 & 19,6 & 13,3 & $*$ & 24 & 0,7 & 1,8 & $*$ \\
\hline $10 \times 10$ & 8 & 5,6 & 1,5 & ns & 6 & 19,6 & 22,7 & $*$ & 20 & 0,7 & 1,5 & ns \\
\hline
\end{tabular}

${ }^{\mathrm{z}}$ Número de quadrats formados dentro da área. ${ }^{y}$ ns: padrão de aleatoriedade de plantas sintomáticas dentro do quadrat. * padrão de agregação de plantas sintomáticas dentro do quadrat.

Vanderplank (1967) argumenta que um patógeno para ter sucesso em causar epidemias, necessita ter propágulos com mecanismos de dispersão difentes, a curtas e longas distâncias. Dispersão apenas a curtas distâncias confinam o patógeno a lesões ou plantas doentes, enquanto que dispersão somente a longas distâncias levam os propágulos bem longe da fonte primária de inóculo, impedindo o progresso da epidemia. A dispersão a curta distância é necessária para que o patóge no colonize e reproduza-se abundantemente em uma área recém-conquistada; dispersão a longas distâncias é necessária para que o patógeno amplie a sua distribuição geográfica (Bergamin Filho et al., 2002). No caso da MPC, os esporos assexuais são disseminados a curtas distâncias enquanto os esporos sexuais são disseminados a curtas e longas distâncias, ocorrendo uma coerência biológica para isto. Os conídios por terem a mesma 
carga genética, têm maior probabilidade de infectar tecidos da mesma planta, uma vez que a resistência já foi quebrada. Ascósporos formados em folhas em decomposição no solo, têm carga genética diferente entre si, aumentando a probabilidade de infecção de novos tecidos.

O patossistema Guignardia citricarpa - citros, apresenta dois mecanismos de disseminação atuando em conjunto. Plantas com MPC, nos pomares analisados mostraram agregação em raios de até, aproximadamente, 35 metros. Os fatores que podem estar envolvidos na limitação da dispersão dos ascósporos a distâncias maiores, são a arquitetura das plantas, de no mínimo 3 metros de altura, o arranjamento destas plantas no pomar assim como o seu adensamento que reduzem o movimento do ar. Os conídios, devem ter contribuído para o incremento da doença nas plantas e na produção de novas fontes de inóculo de conídios e de ascósporos.

Para a avaliação do tamanho da amostra necessária para determinar a incidência da MPC dentro de uma área, adequou-se o modelo ao binomial negativo, uma vez que todos os mapas obtidos nos experimentos conduzidos nas áreas I, II, III e IV, mostraram um padrão de agregação (Campbell \& Madden, 1990). Portanto, a equação ajustada utilizada foi:

$$
n=\frac{k+x}{x \cdot k \cdot C^{2}}
$$

em que, $n$ é o número de amostras necessárias para estimar a incidência de plantas sintomáticas em uma área, $x$ é a média da incidência de plantas sintomáticas em uma área, $C^{2}$ é o coeficiente de variação da incidência de plantas sintomáticas em uma área e $k$ é o parâmetro da binomial negativa estimado pela variância e média $\left(k=x^{2} /\left(s^{2}-x\right)\right)$. Em cada área experimental avaliourse o número mínimo de amostras necessárias para estimar, com certa precisão ( $C=20 \%)$, a incidência de plantas doentes (Figura 10).

Com o resultado dos 6 mapas plotourse um gráfico onde o número de amostras representou a variável dependente e a incidência, a variável independente (Figura 11). Estes resultados levam em consideração uma área de tamanho médio, fixado em 2143 
plantas (média dos 6 mapas utilizados na análise). Para incidências inferiores a 15\%, o número de plantas a serem amostradas aumenta exponencialmente com o decréscimo da incidência. Acima de 15\%, o número de plantas a serem amostradas é de no mínimo 285, aproximadamente $13 \%$ do número total de plantas dentro do talhão. A amostragem nesse caso deve seguir um padrão aleatório, elegendo-se plantas ao acaso de modo a cobrir toda a extensão da área escolhida.
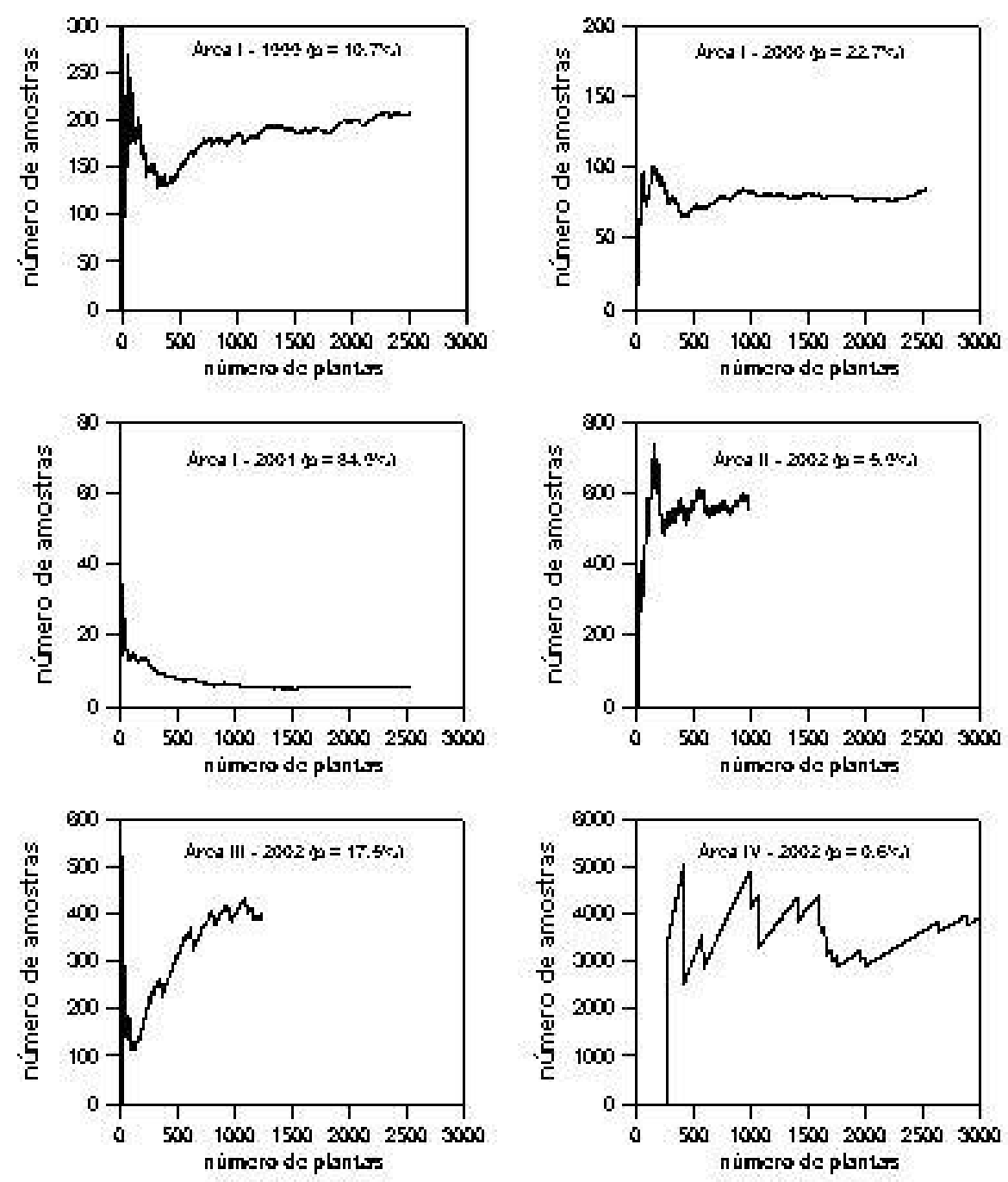

Figura 10 - Número mínimo de plantas amostrais reque ridas para estimar a incidência de mancha preta dos cítricos observada em plantas com frutos sintomáticos em cada levantamento feito nas diferentes áreas amostrais 


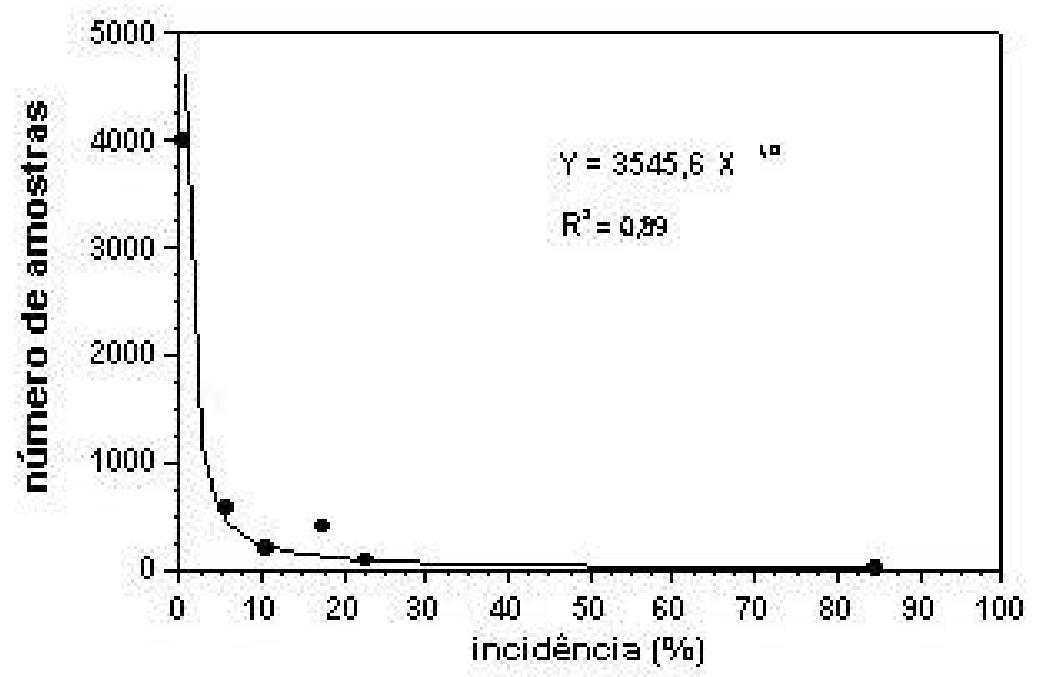

Figura 11 - Número de plantas amostrais requeridas para estimar a incidência de mancha preta dos cítricos em plantas com frutos sintomáticos

\subsection{Conclusões}

O progresso da MPC envolve prioritariamente mecanismos de dispersão a curtas distâncias. Medidas de sanitização devem ser adotadas dentro do pomar como forma de controle da doença, em adição ao tratamento químico protetor. A determinação da incidência da MPC em áreas que produzem frutos cítricos para a comercialização no mercado de fruta fresca, deve ser feita pela observação de todas as plantas do talhão. Nas áreas que produzem frutos para a indústria, o esquema de amostragem ora proposto é suficiente para a determinação da incidência da doença e pode auxiliar o produtor na tomada de decisão para o controle da MPC. 


\section{PADRÃO ESPACIAL DA INCIDÊNCIA DE FRUTOS COM SINTOMAS DE MANCHA PRETA EM PLANTAS CÍTRICAS RELACIONADOS À SEVERIDADE DA DOENÇA E DISPERSÃO DO PATÓGENO}

\section{Resumo}

Guignardia citricarpa, o agente causal da mancha preta dos citros, forma ascósporos nas folhas de citros em decomposição os quais são disseminados pelo vento. Conídios, dispersos pela água, são também formados em folhas em decomposição e em ramos e frutos fixados à planta. Em países onde a doença é endêmica, como a Austrália e África do Sul, apenas os ascósporos têm importância epidemiológica. No Brasil, os conídios de G. citricarpa parecem contribuir para o progresso da doença. Nesse trabalho, o padrão espacial da doença em frutos fi usado para diferenciar ambos os mecanismos de dispersão e determinar a importância de conídios e ascósporos na epidemiologia da mancha preta dos citros. A agregação de frutos sintomáticos na planta foi quantificada pelo índice de dispersão binomial $(D)$ e pela forma binária da lei de Taylor para 303 plantas de seis pomares comerciais. $O$ índice de dispersão binomial foi significativamente maior do que 1 em $84 \%$ das plantas. O intercepto da linha de regressão da forma binária da lei de Taylor $(\log (A))$ foi significativamente maior que $0 \mathrm{e}$ a inclinação não foi diferente de 1 , interpretado como uma agregação de frutos sintomáticos independentemente do nível de incidência da doença. A relação incidênciaseveridade foi descrita pelo modelo exponencial $S=0,0034 \exp (2,7 I)$ com um baixo coeficiente de determinação $\left(R^{2}=0,38\right)$. Esse baixo $R^{2}$ foi causado pela presença de uma mistura de sintomas nos frutos. Para o mesmo nível de incidência da doença várias 
plantas que tiveram frutos sintomáticos com alta severidade da doença e outras plantas apresentaram frutos com baixa severidade da doença. A agregação de frutos sintomáticos na planta sugere que os conídios de G. citricarpa são importantes para a epidemiologia da doença no Brasil em adição aos ascósporos, o que reforça a necessidade de mudanças no manejo da doença.

\section{Summary}

\section{Spatial Pattern of Incidence of Citrus Black Spot Symptomatic Fruits Associated to Disease Severity and Pathogen Dispersal}

The fungus Guignardia citricarpa, the causal agent of citrus black spot (CBS), produce ascospores in the soil leaves that are disseminated by wind. Conidia, dispersed by water, are also produce in soil leaves and plant twigs and fruits. In countries that the disease is endemic, such as Australia and South Africa, only ascospores are epidemiological important. However, in Brazil, conidia of G. citricarpa seem to contribute to disease development. In the present study, the spatial distribution of the CBS in fruit was used to differentiate both dispersion strategies and determine the importance of conidia and ascospores in the epidemiology of CBS. The binomial dispersion $(D)$ index and binary form of Taylor's Power Law was used for quantified the aggregation of symptomatic fruits in the 303 plant from six commercial orchard. The $D$ index was significantly higher than 1 in $84 \%$ of the evaluated plants. The intersection of the regression line obtained with binary form of Taylor's Power Law $(\log (A))$ was significantly higher than 0 and the inclination was not different of 1 , allowing the interpretation that the symptomatic fruit aggregation occurr independently of the level of CBS incidence. The incidence-severity relation was described by the exponential model $S=0.0034 \exp (2.7$ I) with a low determination coefficient $\left(R^{2}=0.38\right)$. This low $R^{2}$ was caused by the occurrence of more than one type of symptoms. Plants showing low and high severity of the disease was verified in orchards with the same incidence level of the CBS The aggregation of symptomatic fruit in the plant suggest that besides the ascospores, the 
conidia of G. citricarpa are important in the CBS epidemiology in Brazil, showing that shifts in disease manage should be carried out.

\subsection{Introdução}

A mancha preta, causada pelo fungo Guignardia citricarpa, é uma das mais importantes doenças dos citros na região sul do Estado de São Paulo. Guignardia citricarpa produz ascocarpos e ascósporos em folhas caídas e em decomposição no solo. Os ascósporos são liberados pela chuva (McOnie, 1964a; Smith, 1996) e transportados pelo vento até as partes suscetíveis da planta, onde ocorre a infecção primária (Kotzé, 1963). O período latente varia de 4 a 6 meses (Timmer, 1999). Em frutos e ramos podem ser formados picnídios cujos conídios são dispersos por respingos de chuva a curtas distâncias (Kotzé, 1963). Os sintomas mais comuns nos frutos são a mancha dura e a falsa melanose (Kotzé 1981; 1988). O sintoma de mancha dura corresponde a lesões circulares, deprimidas, com picnídios do fungo ao centro, e com bordos salientes de coloração marrom. A falsa melanose apresenta pequenas manchas pretas distribuídas por todo o fruto e algumas vezes um padrão de "mancha de lágrima", que ocorre quando esporos carregados por água escorrem sobre o fruto. Nas folhas das variedades de laranjeiras doces cultivadas no Estado de São Paulo, o fungo causa infecções assintomáticas (Feichtenberger et al., 1997).

Apesar da adoção do controle químico preventivo na maioria das propriedades do sul do Estado de São Paulo, a incidência da doença vem aumentando desde sua constatação, em 1992 (Goes \& Feichtenberger, 1993).

O controle químico da mancha preta tem sido feito com quatro aplicações de fungicidas protetores, a partir do início da frutificação, a intervalos regulares de 28 dias. Esse programa de aplicações segue as recomendações de controle da África do Sul e da Austrália, onde a doença é endêmica (Kotzé, 1988; Schutte et al., 1997). Naqueles países, esse programa de pulverizações é eficiente, pois há uniformidade de florada e a infecção dos frutos está restrita a três meses, de novembro a janeiro (Kotzé, 1963; 1981; McOnie, 1965). Nesse período há coincidência entre liberação de ascósporos, 
suscetibilidade de frutos e incidência de chuvas (Kotzé, 1988). Naqueles dois países, unicamente ascósporos formados nas folhas cítricas em decomposição têm importância epidemiológica. Os conídios produzidos em frutos com sintomas não infectam outros frutos, uma vez que o longo período latente faz com que sua formação ocorra quando os frutos apresentam resistência à infecção (Kotzé, 1988). Como os frutos são colhidos um mês antes do florescimento da nova safra, não há sobreposição de frutos verdes, suscetíveis, e frutos maduros, fonte de inóculo, numa mesma planta (Kotzé, 1981). Outra evidência do papel secundário dos conídios na epidemiologia da doença é o de que na África do Sul a quantidade de frutos sintomáticos na parte inferior da copa nunca é maior do que na parte superior, como é observado em outras doenças disseminadas por água (McOnie, 1964b; Kotzé, 1963), indicando, portanto, que o inóculo de mancha preta naquela situação está bem distribuído.

O aumento epidêmico da doença no sul do Estado de São Paulo mostra que o programa preventivo de pulverizações tem sido ineficiente. Várias razões podem contribuir para essa situação, mas a mais provável é a presença de um período mais prolongado de infecção associado a floradas sucessivas e irregulares das variedades cultivadas. Picos de liberação de ascósporos foram constatados nessa região entre dezembro e março (Reis, 2002), mas a presença de ascósporos no ar foi observada também fora desse período (Goes, 1998). O período de suscetibilidade dos frutos também é maior no Brasil do que na África do Sul. Nas variedades tardias 'Valência' e 'Natal', os frutos são suscetíveis por pelo menos 6 meses (Baldassari, 2001). Assim, a presença de frutos suscetíveis por um período de tempo mais longo, concomitantemente à presença de esporos aéreos e à elevada freqüência de chuvas de setembro a abril, prolonga o período de infecção. A sobreposição de frutos de diferentes safras também contribui para o incremento de infecções conidiais (McOnie1964b; Kotzé, 1996; Feichtenberger, 1996).

A importância relativa de conídios no progresso da doença pode também ser analisada pela agregação e pela localização de frutos doentes na planta. A aleatoriedade e a agregação dos frutos doentes na copa são indicativos, respectivamente, de dispersão ao acaso e agregada. A agregação é típica de esporos veiculados pela água (Madden, 
1992). Dessa forma, se os frutos doentes estiverem agrupados na copa da planta, com algumas regiões com muita doença e outras com nada ou quase nada, é provável que o inóculo tenha sido disperso por água. A localização dos frutos doentes também pode estar relacionada ao tipo de dispersão do patógeno e, conseqüentemente, ao tipo de inóculo. Frutos doentes na parte mais alta da copa indicam infecção por esporos aéreos, enquanto que frutos doentes na parte inferior da copa podem ter sido infectados tanto por esporos aéreos quanto por esporos transportados por água.

A análise das relações entre a incidência e a severidade da mancha preta, considerando a planta como unidade amostral, pode auxiliar na descrição do padrão espacial da doença (Seem, 1984) e levar a inferências sobre a dispersão do patógeno. A relação incidência-severidade é usualmente descrita por equações empíricas com o objetivo de se estimar a severidade, conhecendo-se apenas a incidência da doença (Dillard \& Seem, 1990; Edwards et al., 2000).

Os objetivos desse trabalho foram: (i) verificar se há relação entre incidência e severidade de mancha preta, (ii) analisar o padrão espacial da incidência de frutos com mancha preta em plantas de diferentes pomares do Estado de São Paulo, por meio de índices de dispersão binomial (Madden \& Hughes, 1995) e por análise de variância, considerando diferentes alturas da copa.

\subsection{Material e Métodos}

\subsubsection{Relação incidência-severidade}

A incidência da doença (porcentagem de frutos doentes por planta) e a severidade da doença (porcentagem da área dos frutos com sintomas) foram avaliadas em 34.550 frutos, provenientes de 691 plantas de pomar naturalmente infectado do Estado de São Paulo, em 2003. A severidade foi estimada com o auxílio de escala diagramática (Spósito et al., 2003). Cada avaliação foi feita por um mínimo de 2 e um máximo de 3 pessoas, com experiência na estimativa da severidade de mancha preta dos citros com escalas diagramáticas. 
A unidade amostral foi a planta e os dados referem se à porcentagem de frutos com sintomas de mancha preta dos citros por planta (incidência, I) e à porcentagem média de área com sintomas de todos os frutos amostrados por planta (severidade, $S$ ). Três modelos impíricos foram ajustados para os dados: linear, exponencial e potência, de acordo com metodologia descrita por Lalancette \& Robison (2002). Devido à alta variação na severidade da doença, quando a incidência foi de $100 \%$, os pontos foram eliminados (62 pontos) para a análise de regressão. A escolha do melhor modelo foi feita pela análise do coeficiente de determinação $\left(R^{2}\right)$ e pela análise da distribuição dos resíduos.

\subsubsection{Padrão espacial de frutos doentes}

A presença de mancha preta foi avaliada em 27.270 frutos, provenientes de 303 plantas de seis pomares naturalmente infectados do Estado de São Paulo, em duas safras (Tabela 8).

Tabela 8. Áreas amostrais, variedades de laranja doce, número de plantas avaliadas e data das avaliações de incidência de mancha preta dos citros usadas na análise de padrão espacial de frutos sintomáticos na planta

\begin{tabular}{cccc}
\hline Área & Variedade & Número de plantas & Data da avaliação \\
\hline I & 'Hamlin' & 25 & Julho de 2002 \\
II & 'Natal' & 18 & Julho de 2002 \\
III & 'Natal' & 50 & Outubro de 2001 \\
IV & 'Valência' & 80 & Julho de 2002 \\
V & 'Valência' & 80 & Julho de 2002 \\
VI & 'Natal' & 50 & Dezembro de 2001 \\
\hline
\end{tabular}

A proporção de frutos com sintomas foi avaliada em 18 áreas da copa da planta, denominadas quadrats na terminologia estatística (Hughes et al., 1996), 9 em cada lado da planta. A distribuição dos quadrats na planta foi regular com seis quadrats no terço 
superior, seis no terço mediano e seis no inferior. Em cada quadrat foram avaliados 5 frutos, totalizando 90 frutos por planta (Figura 12). A partir destes dados foi calculado o índice de dispersão $(D)$ para dados binários: $D=s^{2} /[I(1-I) / n]$, em que $s^{2}$ é a variância observada ( $\left.V_{\text {obs }}\right)$ entre quadrats e $I(1-I) / n$ é a variância da distribuição binomial $\left(V_{\text {bin }}\right)$, na qual $n$ representa o número de frutos por quadrat e $I$ a incidência de frutos doentes na planta (Madden \& Hughes, 1995). Aos valores de $D$ para cada planta foi aplicado o teste do $\chi^{2}$ (chi-quadrado) para verificar se o valor calculado foi maior ou igual a 1 ao nível de significância de $5 \%$. Valores de $D$ iguais a 1 indicam que os frutos com sintomas estão distribuídos aleatoriamente na planta (ao acaso). Valores de $D$ significativamente maiores que 1 indicam que os frutos com sintomas estão agregados, isto é, concentrados em determinadas regiões (quadrats) da planta (Madden \& Hughes, 1995).

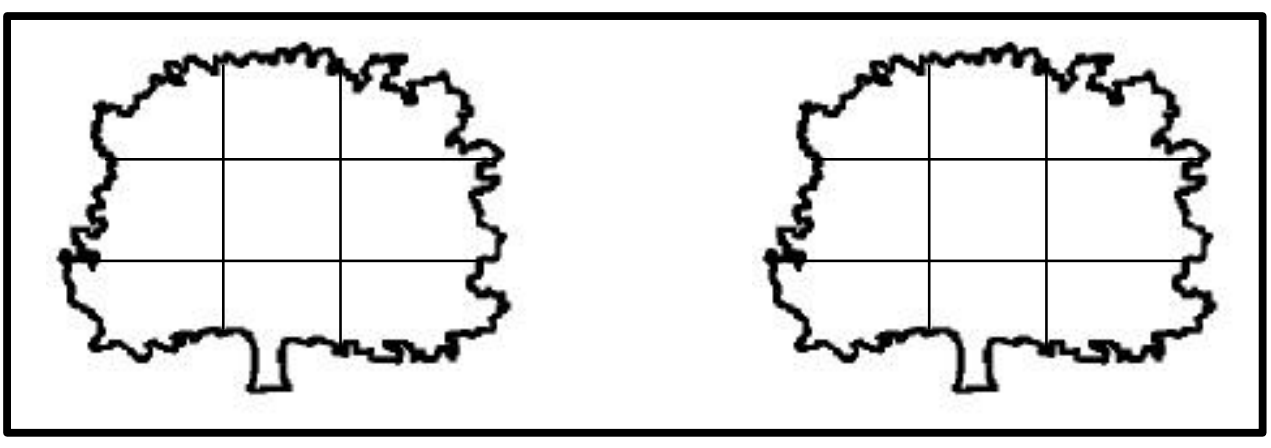

Figura 12 - Esquema de avaliação, com 18 quadrats por planta (nove quadrats de cada lado da planta), para obtenção da proporção de frutos com sintomas de MPC por planta

A forma binária da lei de Taylor (Hughes \& Madden, 1992) relaciona a variância observada $\left(V_{\text {obs }}\right)$ e a variância binomial esperada $\left(V_{\text {bin }}\right)$ para uma distribuição ao acaso de dados binários. Nesse caso, $\log \left(V_{\mathrm{obs}}\right)=\log (A)+b \log \left(V_{\text {bin }}\right)$, onde $A$ e $b$ são parâmetros. A regressão linear, calculada pelo método dos quadrados mínimos, foi aplicada a todos os dados obtidos nas diferentes propriedades conjuntamente, considerando a variância binomial a variável independente e a variância observada a variável dependente. A significância da regressão entre o $\log \left(V_{\mathrm{obs}}\right)$ e o $\log \left(V_{\text {bin }}\right)$ foi determinada pelo teste $\mathrm{F}$ e a adequação do ajuste foi avaliada pelo coeficiente de determinação $\left(R^{2}\right)$ e pela análise da 
distribuição de resíduos. A distribuição ao acaso dos frutos sintomáticos é inferida quando $b=A=1$. Há um nível constante de agregação para todos os valores de incidência quando $b=1$ e $A>1$. Quando $b>1$, o nível de agregação varia com a incidência (Madden $\&$ Hughes, 1995). A igualdade dos parâmetros $A$ e $b$ a 1 foi testada pelo teste $t$, usado para estimar os parâmetros e os desvios padrões (Campbell \& Madden, 1990).

As médias dos frutos doentes no terço superior, terço mediano e terço inferior das plantas foram comparadas pelo teste de Tukey a 5\% de probabilidade. Para a análise estatística, a proporção de frutos doentes $(x)$ foi transformada em arco seno $\sqrt{(x+1)}$. O delineamento experimental foi inteiramente casualizado e as repetições foram as plantas avaliadas emcada área.

\subsection{Resultados e Discussão}

\subsubsection{Relação incidência-severidade}

O modelo exponencial foi o que melhor se ajustou aos dados quando comparado com os modelos linear e potência (Tabela 9). Entretanto, com o modelo exponencial o coeficiente de determinação foi baixo $\left(R^{2}=0,38\right)$. Isto se deveu a uma alta dispersão dos pontos (Figura 13). Para os dados totais de incidência da doença, algumas plantas tiveram a maioria dos frutos com uma alta severidade enquanto que outras plantas tiveram a maioria dos frutos com baixa severidade.

Relações entre incidência e severidade de doença têm sido estabelecidas em diferentes patossistemas por modelos empíricos (Rouse et al., 1981; Dillard \& Seem, 1990; Silva-Acuña et al., 1999; Edwards et al., 2000) com o objetivo de facilitar a avaliação de doença no campo, economizando tempo e recursos sem comprometer a acurácia e a precisão da estimativa da severidade. O melhor ajuste para os dados de mancha preta dos citros foi obtido pelo modelo exponencial, entretanto o baixo valor do coeficiente de determinação da regressão demostrou que não há uma relação direta entre a incidência e a severidade da doença. Esporos dispersos por água podem apresentar severidade alta mesmo com uma incidência da doença baixa. Quando o patógeno é 
disseminado por respingo de chuva, algumas gotas de água podem carregar vários esporos desde uma única lesão. O padrão de sintomas resultante desse tipo de dispersão é típico de agregação (Waggoner \& Rich, 1981). A não relação entre a incidência e severidade de mancha preta em frutos cítricos pode estar relacionado às duas maneiras de dispersão que G. citricarpa possui, pelo vento (ascósporos) e por respingo de chuva (conídios), fazendo com que possa ocorrer alta incidência com baixa severidade da doença, assim como baixa incidência e alta severidade da doença.

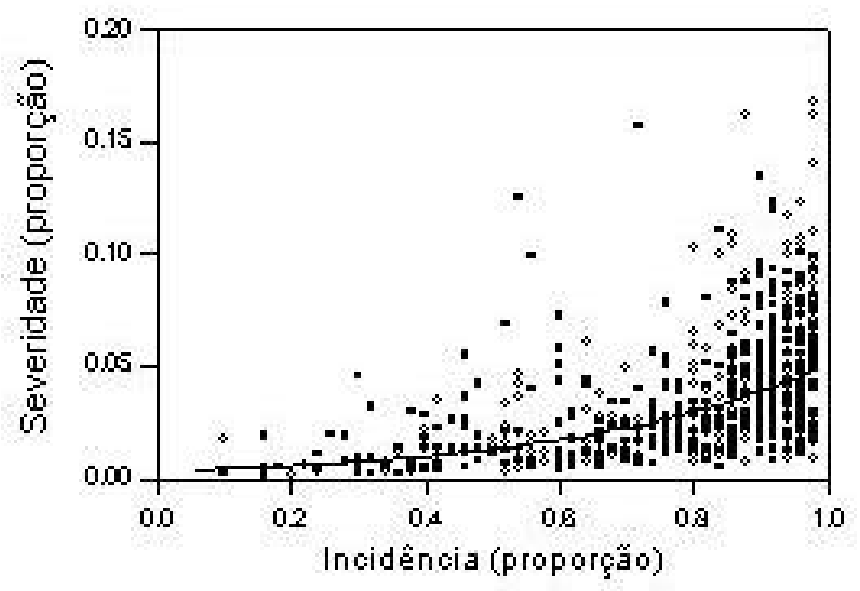

Figura 13 - Incidência $v s$ severidade de mancha preta de citros. Os pontos indicam os valores estimados de cada planta e a linha representa o ajuste do modelo $S=$ $a \exp (b I)$, no qual $S$ é a severidade e $I$ a incidência da doença

Tabela 9. Parametros dos modelos exponencial $S=a \exp (b I)$, potência $S=a I^{b}$, e linear $\mathrm{S}=a+b I$, em que $S$ é a severidade e Ié a incidência da MPC, e $\left(R^{2}\right)$ o coeficiente de determinação da regressão entre a incidência e a severidade aplicado aos dados da doença

\begin{tabular}{cccc}
\hline Modelo & $a$ & $b$ & $R^{2}$ \\
\hline Exponencial & 0,003 & 2,70 & 0,38 \\
Potência & 0,043 & 1,48 & 0,35 \\
Linear & 0,071 & 0,02 & 0,23 \\
\hline
\end{tabular}




\subsubsection{Padrão espacial de frutos doentes}

Agregação de frutos doentes foi constatada em 255 das 303 plantas avaliadas (84\%), em diferentes níveis de incidência da doença. Em todas as áreas avaliadas a agregação de frutos doentes foi superior a $75 \%$ (Tabela 10). Isso indica que, na maioria das plantas, os frutos doentes estavam reunidos em uma determinada área (quadrat) da copa. A presença de vários frutos doentes em um único ramo rodeados por ramos com frutos sadios foi observada em todos os pomares avaliados. Mesmo quando a incidência foi muito baixa, como de 2,2\% (2 frutos sintomáticos na planta), o padrão de distribuição dos frutos na copa não foi ao acaso (Tabela 10). Das 48 plantas em que o padrão de aleatoriedade foi detectado, 11 apresentavam apenas 1 fruto doente na planta $(p=1,1 \%)$, impossibilitando qualquer medida de agregação (Tabela 10).

Tabela 10. Incidência $(I)$ de mancha preta e o índice de dispersão binomial $(D)$ por planta avaliada em seis áreas no Estado de São Paulo

\begin{tabular}{|c|c|c|c|c|c|c|c|c|c|c|c|c|c|c|c|c|c|c|}
\hline \multirow[t]{2}{*}{ Plant } & \multicolumn{3}{|c|}{ Area I } & \multicolumn{3}{|c|}{ Area II } & \multicolumn{3}{|c|}{ Area III } & \multicolumn{3}{|c|}{ Area IV } & \multicolumn{3}{|c|}{ Area V } & \multicolumn{3}{|c|}{ Area VI } \\
\hline & $I$ & $D^{(1)}$ & & $I$ & $D^{(1)}$ & & $I$ & $D^{\prime}$ & & $I$ & $D^{(1)}$ & & $I$ & $D^{\prime}$ & & $I$ & $D^{(1)}$ & \\
\hline 1 & 7,8 & 3,65 & $*$ & 3,3 & 3,10 & & 8,9 & 4,42 & $*$ & 56,7 & 2,93 & & 31,1 & 1,78 & $\mathrm{~ns}$ & 11,1 & 2,66 & \\
\hline 2 & 7,8 & 1,98 & 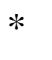 & 3,3 & 3,10 & * & 5,5 & 5,29 & $*$ & 46,7 & 1,51 & $\mathrm{~ns}$ & 35,6 & 1,80 & $\mathrm{~ns}$ & 21,1 & 2,89 & 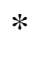 \\
\hline 3 & 1,1 & 1,01 & ns & 4,4 & 2,52 & $*$ & 2,2 & 0,96 & ns & 33,3 & 1,80 & ns & 28,9 & 2,43 & $*$ & 3,3 & 3,10 & * \\
\hline 4 & 1,1 & 1,01 & ns & 5,6 & 3,50 & $*$ & 4,4 & 4,18 & $*$ & 44,4 & 1,77 & $\mathrm{~ns}$ & 38,9 & 3,02 & $*$ & 5,6 & 2,6 & * \\
\hline 5 & 7,8 & 4,31 & $*$ & 10,0 & 2,42 & $*$ & 14,4 & 3,39 & $*$ & 64,4 & 2,60 & $*$ & 55,6 & 2,44 & $*$ & 1,1 & 1,01 & ns \\
\hline 6 & 7,8 & 2,67 & $*$ & 10,0 & 4,02 & $*$ & 3,3 & 1,64 & ns & 74,4 & 3,32 & $*$ & 35,6 & 2,73 & $*$ & 17,7 & 2,75 & $*$ \\
\hline 7 & 2,2 & 2,05 & $*$ & 3,3 & 3,10 & $*$ & 7,8 & 3,65 & $*$ & 91,1 & 2,10 & $*$ & 26,7 & 2,29 & $*$ & 15,6 & 3,14 & $*$ \\
\hline 8 & 7,8 & 2,67 & $*$ & 18,9 & 4,37 & $*$ & 11,1 & 3,86 & $*$ & 74,4 & 3,44 & $*$ & 37,8 & 2,09 & $*$ & 7,8 & 3,98 & * \\
\hline 9 & 7,8 & 3,65 & $*$ & 5,6 & 2,60 & $*$ & 2,2 & 2,04 & $*$ & 51,1 & 2,47 & $*$ & 28,9 & 2,43 & $*$ & 7,8 & 2,67 & * \\
\hline 10 & 6,7 & 3,03 & $*$ & 21,1 & 3,60 & $*$ & 8,9 & 3,84 & $*$ & 72,2 & 2,83 & $*$ & 23,3 & 2,80 & * & 14,4 & 3,39 & \\
\hline
\end{tabular}


Tabela 10. Incidência $(I)$ de mancha preta e o índice de dispersão binomial $(D)$ por planta avaliada em seis áreas no Estado de São Paulo

\begin{tabular}{|c|c|c|c|c|c|c|c|c|c|c|c|c|c|c|c|c|c|c|}
\hline \multirow[t]{2}{*}{ Plant } & \multicolumn{3}{|c|}{ Area 1} & \multicolumn{3}{|c|}{ Area II } & \multicolumn{3}{|c|}{ Area III } & \multicolumn{3}{|c|}{ Area IV } & \multicolumn{3}{|c|}{ Area V } & \multicolumn{3}{|c|}{ Area VI } \\
\hline & $I$ & $D^{4}$ & & $I$ & $D^{\prime \prime}$ & & $I$ & $D^{\prime}$ & & $I$ & $D^{11}$ & & $I$ & $D^{\prime}$ & & $I$ & $D^{11}$ & \\
\hline 11 & 5,6 & 3,50 & * & 3,3 & 3,10 & & 8,9 & 2,67 & $*$ & 70,0 & 3,61 & $*$ & 27,8 & 1,42 & $\mathrm{~ns}$ & 6,7 & 3,02 & * \\
\hline 12 & 4,4 & 6,56 & $*$ & 3,3 & 1,64 & ns & 4,4 & 4,18 & $*$ & 68,9 & 2,77 & $*$ & 36,7 & 3,67 & $*$ & 25,6 & 3,31 & * \\
\hline 13 & 6,7 & 2,27 & $*$ & 6,7 & 2,27 & $*$ & 10,0 & 4,77 & $*$ & 67,8 & 3,03 & $*$ & 32,2 & 2,39 & $*$ & 22,2 & 2,43 & $*$ \\
\hline 14 & 5,6 & 2,16 & * & 3,3 & 1,64 & ns & 4,4 & 4,18 & $*$ & 63,3 & 3,57 & $*$ & 27,8 & 2,24 & $*$ & 12,2 & 2,66 & $*$ \\
\hline 15 & 2,2 & 2,05 & $*$ & 2,2 & 2,05 & $*$ & 14,4 & 3,58 & $*$ & 50,0 & 2,75 & $*$ & 31,1 & 2,00 & $*$ & 32,2 & 3,14 & $*$ \\
\hline 16 & 5,6 & 2,60 & $*$ & 3,3 & 3,10 & * & 3,3 & 3,10 & $*$ & 41,1 & 2,18 & $*$ & 20,0 & 2,50 & $*$ & 7,8 & 2,01 & $*$ \\
\hline 17 & 2,2 & 2,05 & $*$ & 1,1 & 1,01 & ns & 20,0 & 3,68 & $*$ & 66,7 & 2,96 & $*$ & 27,8 & 2,36 & $*$ & 1,1 & 1,01 & ns \\
\hline 18 & 4,4 & 4,19 & $*$ & 4,4 & 1,42 & $\mathrm{~ns}$ & 3,3 & 1,64 & $\mathrm{~ns}$ & 67,8 & 2,68 & $*$ & 27,8 & 2,48 & $*$ & 6,7 & 1,51 & ns \\
\hline 19 & 1,1 & 1,01 & ns & & & & 6,7 & 3,40 & $*$ & 71,1 & 2,66 & $*$ & 36,7 & 2,15 & $*$ & 13,3 & 2,65 & $*$ \\
\hline 20 & 6,7 & 2,27 & $*$ & & & & 7,8 & 2,99 & $*$ & 74,4 & 1,34 & ns & 30,0 & 1,37 & ns & 13,3 & 3,46 & $*$ \\
\hline 21 & 4,4 & 6,22 & $*$ & & & & 11,1 & 5,29 & $*$ & 74,4 & 2,70 & $*$ & 47,8 & 3,50 & $*$ & 12,2 & 1,78 & ns \\
\hline 22 & 2,2 & 2,05 & $*$ & & & & 4,4 & 4,18 & $*$ & 65,6 & 2,79 & $*$ & 53,3 & 2,46 & $*$ & 10,0 & 2,41 & $*$ \\
\hline 23 & 1,1 & 1,01 & ns & & & & 4,4 & 4,18 & $*$ & 86,7 & 2,04 & $*$ & 44,4 & 3,29 & * & 14,4 & 2,81 & $*$ \\
\hline 24 & 1,1 & 1,01 & ns & & & & 15,5 & 4,93 & $*$ & 64,4 & 2,73 & $*$ & 37,8 & 2,19 & $*$ & 17,7 & 4,32 & $*$ \\
\hline 25 & 3,3 & 3,10 & $*$ & & & & 1,1 & 1,01 & ns & 68,9 & 2,66 & $*$ & 42,2 & 2,50 & * & 1,1 & 1,01 & ns \\
\hline 26 & & & & & & & 50,0 & 2,84 & $*$ & 68,9 & 2,44 & $*$ & 55,6 & 3,39 & $*$ & 5,6 & 2,6 & $*$ \\
\hline 27 & & & & & & & 7,8 & 2,67 & $*$ & 65,6 & 2,17 & $*$ & 35,6 & 1,70 & ns & 7,8 & 2,67 & $*$ \\
\hline 28 & & & & & & & 15,5 & 4,39 & $*$ & 44,4 & 2,72 & $*$ & 40,0 & 1,96 & $*$ & 6,7 & 3,02 & $*$ \\
\hline 29 & & & & & & & 22,2 & 4,47 & $*$ & 52,2 & 1,90 & ns & 53,3 & 2,65 & $*$ & 6,7 & 2,27 & $*$ \\
\hline 30 & & & & & & & 2,2 & 2,04 & $*$ & 62,2 & 2,79 & $*$ & 40,0 & 2,84 & $*$ & 12,2 & 3,10 & $*$ \\
\hline 31 & & & & & & & 2,2 & 2,04 & $*$ & 68,9 & 1,67 & ns & 54,4 & 1,61 & ns & 6,7 & 2,26 & * \\
\hline
\end{tabular}


Tabela 10. Incidência ( $I$ ) de mancha preta e o índice de dispersão binomial $(D)$ por planta avaliada em seis áreas no Estado de São Paulo

\begin{tabular}{|c|c|c|c|c|c|c|c|c|c|c|c|c|c|c|c|c|}
\hline \multirow[t]{2}{*}{ Plant } & \multicolumn{2}{|c|}{ Area I } & \multicolumn{2}{|c|}{ Area II } & \multicolumn{3}{|c|}{ Area III } & \multicolumn{3}{|c|}{ Area IV } & \multicolumn{3}{|c|}{ Area V } & \multicolumn{3}{|c|}{ Area VI } \\
\hline & $I$ & $D^{(1)}$ & $I$ & $D^{(1)}$ & $I$ & $D^{\prime}$ & & $I$ & $D^{\prime}$ & & $I$ & $D$ & & $I$ & $D^{\prime}$ & \\
\hline 32 & & & & & 4,4 & 4,18 & $*$ & 60,0 & 2,65 & & 33,3 & 1,91 & $\mathrm{~ns}$ & 5,5 & 3,5 & $*$ \\
\hline 33 & & & & & 4,4 & 2,52 & $*$ & 61,1 & 1,53 & ns & 57,8 & 3,56 & $*$ & 17,7 & 2,52 & $*$ \\
\hline 34 & & & & & 6,7 & 4,54 & $*$ & 51,1 & 2,47 & $*$ & 71,1 & 1,86 & ns & 5,5 & 1,70 & $\mathrm{~ns}$ \\
\hline 35 & & & & & 7,8 & 2,99 & $*$ & 72,2 & 3,53 & $*$ & 25,6 & 1,83 & ns & 4,4 & 1,41 & ns \\
\hline 36 & & & & & 3,3 & 3,10 & $*$ & 70,0 & 2,27 & $*$ & 47,8 & 3,04 & $*$ & 7,8 & 2,01 & $*$ \\
\hline 37 & & & & & 2,2 & 2,04 & $*$ & 60,0 & 2,16 & $*$ & 52,2 & 2,09 & $*$ & 5,5 & 2,6 & $*$ \\
\hline 38 & & & & & 10,0 & 4,77 & $*$ & 41,1 & 1,99 & $*$ & 58,9 & 3,16 & $*$ & 15,5 & 2,96 & $*$ \\
\hline 39 & & & & & 8,9 & 4,42 & $*$ & 92,2 & 1,69 & ns & 40,0 & 2,84 & $*$ & 6,7 & 1,13 & ns \\
\hline 40 & & & & & 5,5 & 5,29 & $*$ & 51,1 & 2,09 & $*$ & 36,7 & 2,36 & $*$ & 5,5 & 1,70 & ns \\
\hline 41 & & & & & 2,2 & 2,04 & $*$ & 37,8 & 3,09 & $*$ & 44,4 & 3,39 & $*$ & 1,1 & 1,01 & ns \\
\hline 42 & & & & & 24,4 & 4,53 & $*$ & 35,6 & 1,91 & ns & 44,4 & 2,82 & $*$ & 4,4 & 2,52 & $*$ \\
\hline 43 & & & & & 4,4 & 4,18 & $*$ & 25,6 & 2,33 & $*$ & 52,2 & 2,94 & $*$ & 16,7 & 3,76 & $*$ \\
\hline 44 & & & & & 11,1 & 3,86 & $*$ & 40,0 & 2,55 & $*$ & 38,9 & 2,52 & $*$ & 16,7 & 4,10 & $*$ \\
\hline 45 & & & & & 7,8 & 3,65 & $*$ & 38,9 & 3,21 & $*$ & 31,1 & 1,78 & ns & 12,2 & 2,88 & $*$ \\
\hline 46 & & & & & 2,2 & 2,04 & $*$ & 32,2 & 1,74 & ns & 61,1 & 2,92 & $*$ & 13,3 & 2,44 & $*$ \\
\hline 47 & & & & & 16,7 & 4,27 & $*$ & 31,1 & 1,89 & ns & 57,8 & 3,37 & $*$ & 8,9 & 2,67 & $*$ \\
\hline 48 & & & & & 14,4 & 4,72 & * & 33,3 & 2,01 & $*$ & 34,4 & 2,79 & $*$ & 2,2 & 0,96 & ns \\
\hline 49 & & & & & 7,8 & 3,65 & $*$ & 33,3 & 2,33 & $*$ & 43,3 & 2,80 & $*$ & 10,0 & 2,41 & $*$ \\
\hline 50 & & & & & 26,6 & 4,69 & * & 31,1 & 2,44 & $*$ & 22,2 & 1,62 & ns & 3,3 & 1,64 & $\mathrm{~ns}$ \\
\hline 51 & & & & & & & & 43,3 & 2,23 & $*$ & 45,6 & 1,97 & $*$ & & & \\
\hline 52 & & & & & & & & 28,9 & 3,39 & $*$ & 42,2 & 2,21 & $*$ & & & \\
\hline
\end{tabular}


Tabela 10. Incidência $(I)$ de mancha preta e o índice de dispersão binomial $(D)$ por planta avaliada em seis áreas no Estado de São Paulo

\begin{tabular}{|c|c|c|c|c|c|c|c|c|c|c|c|c|c|c|}
\hline \multirow[t]{2}{*}{ Plant } & \multicolumn{2}{|c|}{ Area 1} & \multicolumn{2}{|c|}{ Area II } & \multicolumn{2}{|c|}{ Area III } & \multicolumn{3}{|c|}{ Area IV } & \multicolumn{3}{|c|}{ Area V } & \multicolumn{2}{|c|}{ Area VI } \\
\hline & $I$ & $D^{(1)}$ & $I$ & $D^{(1)}$ & $I$ & $D^{(1)}$ & $I$ & $D^{\prime}$ & & $I$ & $D^{\prime}$ & & $I$ & $D^{(1)}$ \\
\hline 53 & & & & & & & 40,0 & 4,71 & & 70,0 & 2,60 & & & \\
\hline 54 & & & & & & & 32,2 & 5,77 & $*$ & 60,0 & 2,84 & $*$ & & \\
\hline 55 & & & & & & & 41,1 & 4,83 & $*$ & 56,7 & 3,18 & $*$ & & \\
\hline 56 & & & & & & & 55,6 & 3,58 & $*$ & 45,6 & 2,07 & $*$ & & \\
\hline 57 & & & & & & & 42,2 & 4,85 & $*$ & 54,4 & 2,54 & $*$ & & \\
\hline 58 & & & & & & & 54,4 & 3,28 & $*$ & 57,8 & 1,82 & ns & & \\
\hline 59 & & & & & & & 42,2 & 7,17 & $*$ & 48,9 & 2,47 & $*$ & & \\
\hline 60 & & & & & & & 46,7 & 3,51 & $*$ & 54,4 & 2,64 & $*$ & & \\
\hline 61 & & & & & & & 38,9 & 4,63 & $*$ & 61,1 & 2,72 & $*$ & & \\
\hline 62 & & & & & & & 42,2 & 3,75 & $*$ & 53,3 & 3,21 & $*$ & & \\
\hline 63 & & & & & & & 41,1 & 2,91 & $*$ & 52,2 & 3,31 & $*$ & & \\
\hline 64 & & & & & & & 54,4 & 3,61 & $*$ & 45,6 & 3,49 & $*$ & & \\
\hline 65 & & & & & & & 45,6 & 2,54 & $*$ & 53,3 & 2,63 & $*$ & & \\
\hline 66 & & & & & & & 54,4 & 3,81 & $*$ & 93,3 & 1,89 & ns & & \\
\hline 67 & & & & & & & 33,3 & 4,92 & $*$ & 65,6 & 1,85 & $\mathrm{~ns}$ & & \\
\hline 68 & & & & & & & 52,2 & 2,40 & $*$ & 62,2 & 2,89 & $\mathrm{~ns}$ & & \\
\hline 69 & & & & & & & 31,1 & 3,78 & $*$ & 74,4 & 2,45 & $*$ & & \\
\hline 70 & & & & & & & 37,8 & 3,49 & $*$ & 71,1 & 2,20 & $*$ & & \\
\hline 71 & & & & & & & 33,3 & 6,36 & $*$ & 54,4 & 2,54 & $*$ & & \\
\hline 72 & & & & & & & 38,9 & 5,15 & $*$ & 47,8 & 2,75 & $*$ & & \\
\hline 73 & & & & & & & 52,2 & 2,78 & $*$ & 83,3 & 2,75 & $*$ & & \\
\hline
\end{tabular}


Tabela 10. Incidência $(I)$ de mancha preta e o índice de dispersão binomial $(D)$ por planta avaliada em seis áreas no Estado de São Paulo

\begin{tabular}{|c|c|c|c|c|c|c|c|c|c|c|c|c|c|c|}
\hline \multirow[t]{2}{*}{ Plant } & \multicolumn{2}{|c|}{ Area 1} & \multicolumn{2}{|c|}{ Area II } & \multicolumn{2}{|c|}{ Area III } & \multicolumn{3}{|c|}{ Area IV } & \multicolumn{3}{|c|}{ Area V } & \multicolumn{2}{|c|}{ Area VI } \\
\hline & $I$ & $D^{(1)}$ & $I$ & $D^{(1)}$ & $I$ & $D^{(1)}$ & $I$ & $D^{(1)}$ & & $I$ & $D^{\prime \prime}$ & & $I$ & $D^{(1)}$ \\
\hline 74 & & & & & & & 43,3 & 2,14 & & 53,3 & 1,89 & ns & & \\
\hline 75 & & & & & & & 33,3 & 10,9 & $*$ & 50,0 & 2,66 & * & & \\
\hline 76 & & & & & & & 45,6 & 2,80 & $*$ & 70,0 & 3,16 & * & & \\
\hline 77 & & & & & & & 28,9 & 2,18 & $*$ & 82,2 & 3,04 & * & & \\
\hline 78 & & & & & & & 40,0 & 2,59 & $*$ & 93,3 & 2,68 & $*$ & & \\
\hline 79 & & & & & & & 50,0 & 4,49 & $*$ & 75,6 & 2,62 & * & & \\
\hline 80 & & & & & & & 41,1 & 2,19 & $*$ & 56,7 & 1,94 & $*$ & & \\
\hline
\end{tabular}

(i) asterícos representam plantas que apresentam padrão de agregação pelo índice de dispersão, a 5\% de probabilidade pelo teste chi-quadrado. ns representa plantas que apresentam padrão de aleatoriedade pelo índice de dispersão, a 5\% de probabilidade pelo teste chi-quadrado.

As relações entre $\log \left(V_{o b s}\right)$ e $\log \left(V_{b i n}\right)$ foram altamente significativas $(P<0,01)$ em todas as áreas. Todas as estimativas de $A$ foram estatisticamente maiores que $1(P<0,05)$, indicando um padrão de agregação em todas as áreas testadas (Tabela 11). Os valores de $b$ foram significativamente maiores que $1(P<0,01)$ apenas nos pomares cuja incidência nas plantas foi menor que 27\% (Tabela 10). Valores de $b$ maiores que 1 também indicam que o grau de agregação variou com a incidência da doença, ou seja, os frutos de plantas com mais doença mostravam maior agregação que aqueles de plantas com menos doença. Nas áreas IV e V, onde a incidência da doença nas plantas variou entre $20 \%$ e 93,3\% (Tabela 10), o grau de agregação foi constante $(A>1 ; b=1)$ para toda a gama de incidência (Tabela 11). Essa situação está relacionada ao tamanho do quadrat, pois o logaritmo da variância binomial é praticamente constante e igual a $-1,3$ no intervalo entre 20 e $80 \%$ de incidência para quadrats de 5 frutos. Os valores constantes da variância binomial formaram um agrupamento de pontos ao redor do valor -1,3 (Figura 14) o que manteve o valor de $b$ em torno de 1 . Quando analisadas as seis áreas em 
conjunto (Figura 14), os parâmetros $A$ e $b$ foram respectivamente de 3,31 e 1,06 com $R^{2}$ igual a 0,87 (Tabela 11). Apenas $A$ foi significativamente diferente de 1 , mostrando que houve agregação, independentemente do valor da incidência.

Tabela 11. Incidência média de frutos sintomáticos de mancha preta dos citros nas áreas avaliadas. Parâmetros $A$ e $b$ da equação ajustada para a lei de Taylor modificada e significancia dos parâmetros pelo teste $t$ nas seis áreas

\begin{tabular}{cccc}
\hline Area & Incidência $(\%)$ & $A$ & $b$ \\
\hline I & 5,70 & $32,47 *$ & $1,56 *$ \\
II & 6,30 & $14,87 *$ & $1,38 *$ \\
III & 9,20 & $9,34 *$ & $1,20 *$ \\
IV & 51,68 & $4,13 *$ & $1,22 \mathrm{~ns}$ \\
V & 47,90 & $4,49 *$ & $1,19 \mathrm{~ns}$ \\
VI & 10,73 & $12,88 *$ & $1,40 *$ \\
Todos & 21,9 & $3,31 *$ & $1,06 \mathrm{~ns}$ \\
* indica que os parâmetros $b$ e $A$ foram maiores que 1 a 1 $1 \%$ de probabilidade pelo teste $t$.
\end{tabular}

Uma menor incidência de frutos sintomáticos foi observada no terço superior, quando comparada aos terços mediano e inferior. Em quatro das seis áreas avaliadas a porcentagem de doença no terço inferior foi maior que no terço mediano da copa (Tabela 12).

O padrão de dispersão do inóculo em cultivos pode ser examinado investigando o padrão de disseminação da doença (Fitt et al., 1989). Neste estudo, a análise espacial foi usada para diferenciar os mecanismos de dispersão de G. citricarpa, investigando o padrão de incidência de frutos doentes na planta. Essa abordagem foi utilizada por Shaw \& Royle (1989) e Schuh (1990) na análise de mancha foliar de Septoria (Septoria tritici - Mycosphaerella graminicola) em trigo e de acordo com esses autores, o padrão de distribuição da doença causada pelo inóculo disseminado por vento é aleatório. Já, o padrão de agregação em frutos de macieira infectados por Monilinia fructigena, 
observado por van Leeuwen et al. (2000), sugere que a disseminação de esporos por respingo de água de chuva teve um importante papel na dinâmica da doença.

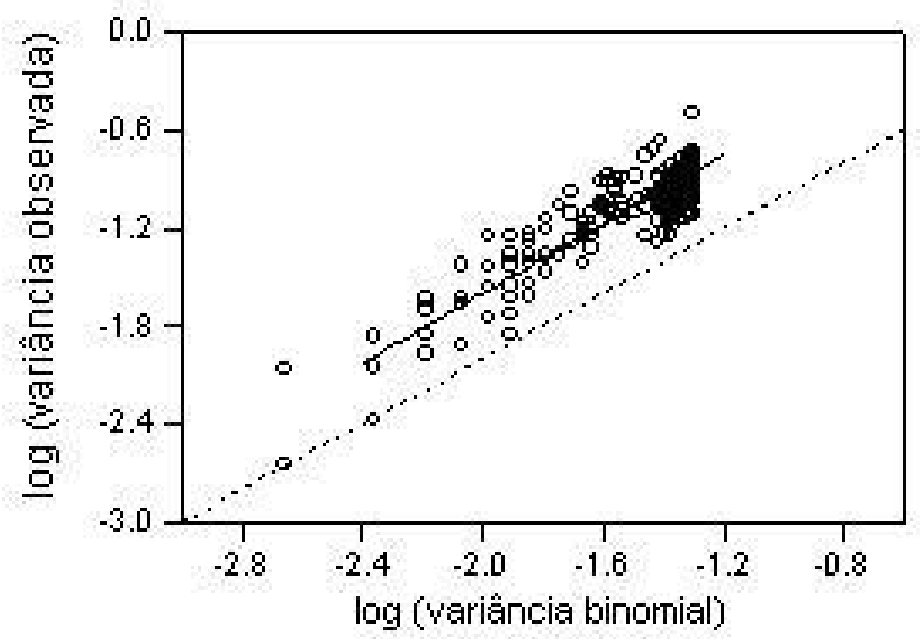

Figura 14 - Relação entre o logaritmo da variância teórica para distribuição binomial (ao acaso) e o logaritmo da variância observada. Linha tracejada para x=y e linha cheia para a análise de regressão linear para o conjunto de dados coletados em seis áreas no Estado de São Paulo

Tabela 12. Porcentagem de frutos com sintomas de mancha preta dos citros em diferentes extratos de altura da copa das plantas, em seis áreas no Estado de São Paulo

\begin{tabular}{ccccccccccccccc}
\hline $\begin{array}{c}\text { Extrato da } \\
\text { planta }\end{array}$ & \multicolumn{1}{c}{ I } & \multicolumn{1}{c}{ II } & & \multicolumn{1}{c}{ III } & IV & & V & & \multicolumn{2}{c}{ VI } \\
\hline Terço superior & 0,67 & a (i) & 0,18 & a & 0,99 & a & 28,54 & a & 27,33 & a & 1,16 & a \\
Terço mediano & 4,53 & b & 6,85 & b & 7,42 & b & 60,04 & b & 52,25 & b & 14,16 & b \\
Terço inferior & 8,39 & c & 11,84 & b & 26,0 & c & 65,45 & b & 64,04 & c & 25,50 & c
\end{tabular}

(i) diferentes letras nas colunas indicam que os resultados diferem significativamente entre si pelo teste de Tukey $(P<0,05)$. 
A incidência de frutos sintomáticos também foi agregada, independentemente da intensidade da doença (Tabela 11). O valor de $D$ indica agregação quando for significativamente maior que 1 e o grau de agregação de futos sintomáticos é alto quando os valores de $D$ são altos. Os valores médios do índice de dispersão encontrados neste trabalho são bastante elevados ( $D=2,72$ para a área I; $D=2,70$ para á área II; $D=3,50$ para a área III, $D=3,04$ e 3,45, respectivamente para as áreas IV e V e $D=2,51$ para a área VI) comparáveis aos valores obtidos para o crestamento foliar do morangueiro, causado por Phomopsis obscurans, que produz conídios que são tipicamente dispersos por gotas de água (Turechek \& Madden, 1999). O D médio para o crestamento foliar do morangueiro foi de 2,3 quando os folíolos foram usados como unidade amostral.

Os parâmetros da forma binária da lei de Taylor aplicada ao conjunto de dados indicam alta agregação independentemente do valor da incidência (Figura 14). Isso ocorre porque, mesmo quando poucos frutos apresentaram sintomas da doença, eles estavam localizados em uma determinada região da planta. A agregação da incidência não é comum em doenças de plantas, exceto para aquelas disseminadas exclusivamente por respingos de chuva. Conídios de G. citricarpa são produzidos em picnídios e são envoltos por mucilagem. Quando molhada, a mucilagem se dissolve e a suspensão conidial é dispersa juntamente com as gotas de chuva ou com o filme de água que escorre pelo fruto. Fungos que possuem esporos envoltos por mucilagem são dispersos a curtas distâncias pela chuva (Fitt et al., 1989). Quando não há vento, poucos esporos atingem mais de 1 metro de distância ou $50 \mathrm{~cm}$ acima da fonte (Fitt et al., 1989). Como consequiência, os órgãos doentes estão geralmente próximos uns aos outros.

Em trabalho recente, Xu \& Madden (2002) mostraram que para oídio da macieira, patógeno tipicamente disperso pelo vento, as folhas sintomáticas nos ramos têm distribuição aleatória. O padrão de agregação de frutos com mancha preta não segue o padrão de patógenos disseminados pelo vento. Isto mostra que o papel dos ascósporos deve ser menos importante que aquele dos conídios no incremento da doença. A maior concentração de frutos doentes na parte inferior da copa corrobora com o resultado obtido por Schinor et al. (2001) para a variedade de laranjeira doce 'Pera'. Essa 
desuniformidade na incidência da doença no plano vertical também sugere uma maior participação de esporos disseminados por água no progresso da doença. Esse padrão também é observado na doença melanose (Diaporthe citri Wolf.), em que conídios (Phomopsis citri) são igualmente disseminados pela ação da água (Kiely, 1948).

\subsection{Conclusões}

As evidências apresentadas neste trabalho reforçam a real necessidade de rever o manejo da mancha preta dos citros empregado no Estado de São Paulo, levando em consideração a participação dos conídios como fonte de inóculo importante para o incremento da doença em condições de campo. 


\section{IMPORTÂNCIA RELATIVA DAS FONTES DE INÓCULO DE GUIGNARDIA CITRICARPA NA EPIDEMIOLOGIA DA MANCHA PRETA DOS CITROS}

\section{Resumo}

O fungo agente causal da MPC apresenta em sua fase epidêmica tanto esporos sexuais, os ascósporos, quanto assexuais, os conídios. A agregação de futos sintomáticos na planta, assim como de plantas sintomáticas no pomar, relatados nos capítulos anteriores (5 e 6), indicam a importância dos conídios no incremento da severidade da doença. $\mathrm{O}$ objetivo do trabalho foi determinar experimentalmente a importância relativa dos ascósporos e dos conídios como inóculos para a mancha preta dos citros em condições naturais de infecção. Para o experimento utilizourse duas áreas. Em uma área foram deixadas decompondo no solo todas as folhas cítricas (fonte de ascósporos) que porventura caíram das plantas durante os dois anos em que foram conduzidos os experimentos. Em outra área retirourse as folhas a cada 30 dias. Em cada área foram marcadas 5 parcelas de 56 plantas onde deixourse por um mês os frutos maduros sintomáticos (fonte de conídios) sobreporem a frutos da nova florada, e 5 parcelas onde retirou-se os frutos maduros antes da florada. Nas duas áreas não foram aplicados qualquer tipo de fungicida durante o período em que conduziu-se o experimento. A eliminação de folhas em decomposição assim como antecipação da colheita auxiliaram na redução da mancha preta dos citros no segundo ano de experimentação, entretanto por si só não abaixaram os níveis de severidade e incidência da doença adequadamente. 


\section{Summary}

\section{Relative Importance of the Source of Guignardia citricarpa Inocula in the Epidemiology of the Citrus Black Spot}

The fungus Guignardia citricarpa, the causal agent of Citrus black spot (CBS), present in the epidemic phase sexual (ascospores) as well as asexual (conidia) spores. The aggregation of symptomatic fruits in the plant as well as symptomatic plants in the orchard, described previously in the present study (charpter 5 and 6) suggesting the importance of the conidia in the increasing of severity disease. Therefore, the aim of the present work was to determine the relative importance of G. citricarpa ascospores and conidia as inocullum of CBS in field conditions, using two experimentally area. In the first area, citrus leaves, that drop the plants during two years experiments, were maintained on the soil surface during decomposition (ascospores source); and in the second area the leaves were picked out from the orchard each 30 days, to avoid ascospores production. In each area, 5 blocks containing 56 plants, the symptomatic fruits (source of conidia) were maintained for 30 days, during the new blossom, and 5 blocks that the symptomatic fruit were early harvested. In the both area fungicides treatment were not used during the experiments. The elimination of the soil leaves as well as the early harvest of the symptomatic fruits resulted in the reduction of CBS in the second evaluation year. However, the incidence and severity level of the disease was not satisfactorily reduced.

\subsection{Introdução}

A mancha preta dos citros (MPC) incitada pelo fungo Guignardia citricarpa causa lesões em frutos de todas as variedades de laranjeiras doce, depreciando-os para o 
mercado interno de fruta fresca, inviabilizando-os para a exportação e podendo causar a sua queda prematura (Aguilar-Vildoso et al., 2002).

O fungo agente causal da MPC apresenta em sua fase epidêmica tanto esporos sexuais, os ascósporos, quanto assexuais, os conídios. Os ascósporos são produzidos em pseudotécios formados em folhas cítricas em decomposição e são disseminados a curtas e longas distâncias pela ação do vento. Os conídios são produzidos em picnídios formados em ramos e frutos fixados à planta e são disseminados a curtas distâncias pela ação da água de chuva (Timmer et al., 2000).

A presença simultânea de propágulos sexuais e assexuais, na fase epidêmica, ocorre em doenças importantes como o mal das folhas da seringueira (Microcyclus ulei) e o mal de Sigatoka da bananeira (Mycosphaerella musicola). Para estas doenças, os dois diferentes esporos formados têm papéis distintos e complementares no crescimento da epidemia. Isto permite que muitas das restrições ambientais que a maioria dos fungos patogênicos possui sejam ignoradas, assegurando não somente a sobrevivência destes patógenos como também o incre mento dessas doenças (Bergamin Filho \& Amorim, 1996).

Em países como a Austrália e a África do Sul, pesquisas com MPC levaram a conclusão de que mesmo com a presença dos esporos sexuais e assexuais do patógeno na fase epidêmica, apenas os ascósporos de Guignardia citricarpa são responsáveis pelo incremento da doença em campo. Essa conclusão está alicerçada em trabalhos onde foram avaliadas a importância dos frutos como fonte de inóculo dentro do pomar e a distribuição da doença no plano vertical da planta (Kiely, 1948; Kotzé, 1963; McOnie, 1964; McOnie, 1965). Entretanto, na África do Sul conídios formados em lesões em frutos são considerados perigosos quando a prática regular de remover todos os frutos antes da nova florada (medida de sanitização para pragas), não é realizada (McOnie, 1964).

Outra característica peculiar da MPC é a de apresentar diferentes sintomas nos frutos cítricos. Os mais comuns são os do tipo mancha dura, caracterizados por lesões circulares com bordas salientes de coloração marrom-escura, cercadas por halo de coloração verde e o centro deprimido e necrótico com pontuações escuras (picnídios), e 
o do tipo falsa melanose, caracterizados por ser pequenas pontuações escuras que podem coalescer tomando grandes extensões dos frutos ou em formato de "mancha de lágrima", similares aos que ocorrem com outra doença fúngica que ataca os citros, a melanose (Diaporthe citri), sem, entretanto serem ásperas (Whiteside et al., 1988).

Resultados dos capítulos 5 e 6 desta tese mostraram que há agregação de frutos doentes na planta e plantas doentes no pomar. Essa agregação em dois níveis hierárquicos diferentes (frutos e plantas) é uma evidência, ainda que circunstancial, de que os conídios são o inóculo de maior importância para o incremento da severidade da doença. No entanto, a prova experimental que referendasse essa conclusão não foi apresentada. Desta forma, o objetivo do trabalho foi determinar experimentalmente a importância relativa dos ascósporos produzidos nas folhas cítricas em decomposição no solo e a dos conídios, produzidos pela sobreposição de frutos maduros sintomáticos com frutos novos suscetíveis, de diferentes safras, como inóculos para a mancha preta dos citros em condições naturais de infecção.

\subsection{Material e Métodos}

Os experimentos foram conduzidos, por 2 anos, em pomar comercial no Estado de São Paulo, onde selecionou-se duas áreas com a variedade 'Valência' (Citrus sinensis Osbeck), enxertada em limão 'Cravo' (Citrus limonia Osbeck), espaçadas de 7,5 m por 3,5 m, com 8 anos de idade, procedentes do mesmo material propagativo e com histórico de MPC. As áreas foram previamente avaliadas quanto a intensidade da MPC, dentro das parcelas marcadas para o experimento (descrito a seguir), não apresentando diferenças significativas para a incidência e severidade observadas nos frutos.

Para o estudo da importância dos ascósporos como inóculo da doença, em uma área de 5,10 ha foram deixados decompondo no solo todas as folhas cítricas que porventura caíram das plantas durante os dois anos em que foram conduzidos os experimentos. Em uma área de 5,12 ha (Figura 15), a cada 30 dias, ao longo do período, foram colhidas com auxílio de um aparelho sugador (Figura 16) todas as folhas cítricas que porventura caíram das plantas, sendo estas retiradas da área e queimadas. Para o 
entendimento da importância dos conídios formados nos frutos, como fonte de inóculo da MPC, em cada uma das áreas (com folha e sem folha), foram efetuados dois tratamentos. No primeiro tratamento, os frutos formados na safra anterior ficaram sobrepostos aos frutos novos da safra seguinte, por um período de um mês. No segundo tratamento, os frutos formados na safra anterior foram colhidos antes da florada seguinte. Cada tratamento teve 5 repetições e cada repetição constou de 56 plantas (7 ruas com 8 plantas). Nas 12 plantas centrais de cada parcela foram avaliados 50 frutos por planta, no período que antecedia a colheita, quanto a incidência (porcentagem de frutos sintomáticos) e a severidade da MPC (porcentagem de casca lesionada pela doença). A severidade foi avaliada com o auxílio de escala diagramática apresentada no capítulo 3 (Spósito et al., 2003). A partir da distribuição de frequiências de frutos nas classes da escala diagramática, foi obtido o índice de intensidade de doença, cuja transformação angular foi submetida à análise de variância, conforme Czermainski (1999).

As áreas não foram tratadas com qualquer tipo de fungicida nos dois anos de experimentação, sendo observado, portanto, somente a ação de cada manejo empregado na redução da intensidade da MPC.

A análise de variância por talhão, a cada ano, foi efetuada segundo o modelo inteiramente ao acaso. Para comparação entre as áreas com e sem folhas, foi efetuada a análise de variância conjunta, considerando-se os efeitos de talhão, de tratamento e a interação entre eles. 


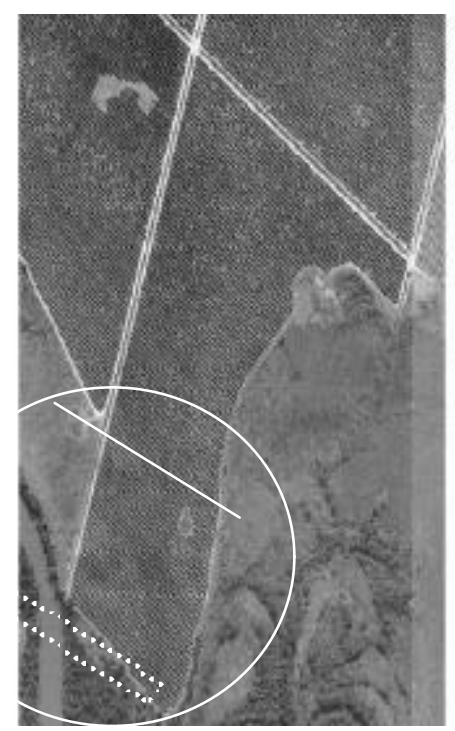

Figura 15 - Área experimental onde foram retiradas mensalmente as folhas dos citros que porventura caíram (círculo) no intuito de suprimir a presença de ascósporos de Guignardia citricarpa. A área amostral onde foram colocadas as 5 repetições dos tratamentos está representada por um retângulo tracejado

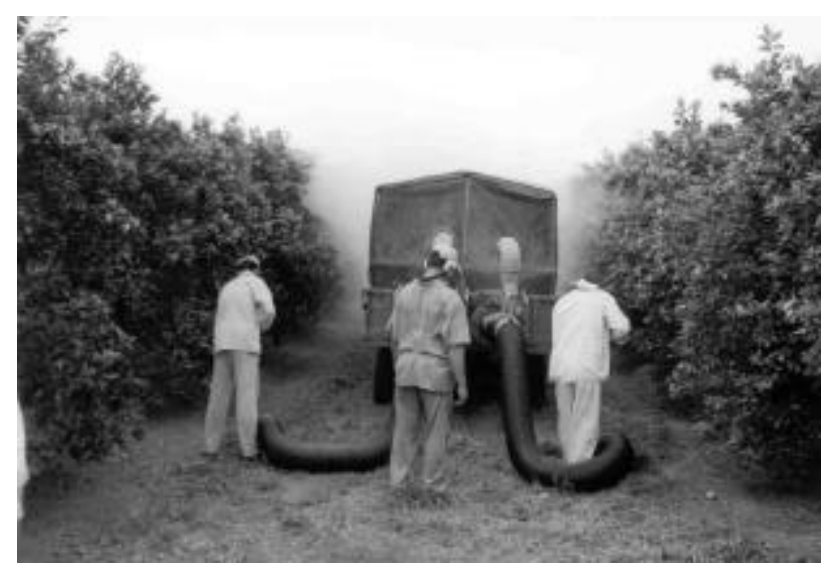

Figura 16 - Retirada das folhas cítricas caídas ao solo na área experimental, com o auxílio de um aparelho sugador, para a supressão de ascósporos 


\subsection{Resultados e Discussão}

Constatou-se alta variabilidade entre as plantas nas parcelas sendo tomada para análises a média de cada parcela.

As áreas amostrais foram avaliadas quanto a incidência e severidade da MPC, antes da montagem do experimento, em 2001, não sendo observadas diferenças significativas da intensidade de doença (Tabela 13).

No primeiro ano de avaliação, em 2002, não foram observadas diferenças significativas entre as áreas com e sem folhas e entre os tratamentos com e sem frutos sobrepostos (Tabela 14). Os resultados observados para os tratamentos com e sem frutos sobrepostos foram semelhantes aos observados por Kotzé (1963) na África do Sul e por Baldassari (2001) em São Paulo. Estes autores concluíram que os frutos não eram fonte de inóculo para o incremento da doença no campo.

Entretanto, as análises de variância individuais feitas por área amostral (com folhas e sem folhas), no segundo ano de avaliação, 2003, indicaram diferenças significativas entre os tratamentos quanto à intensidade de doença, para os tratamentos com frutos sobrepostos e não sobrepostos à nova florada $(P<0,09$, na área com folha $\mathrm{e}$ $P<0,02$, na área sem folha) (Tabela 15). Este incremento da intensidade de doença observado nos frutos que estiveram sobrepostos evidencia um aumento da severidade da doença, uma vez que todos os frutos apresentavam sintomas (Tabela 15). Este incremento da severidade provavelmente está relacionado com esporos disseminados por água a curtas distâncias.

Quando analisourse a intensidade média de doença entre as áreas com folha e sem folha, foram observadas diferenças significativas $(\alpha<0,001)$ tão somente no segundo ano de avaliação, em 2003 (Tabela 15). O incremento da incidência da doença nas duas áreas para este ano mostrou que mesmo com a retirada dos frutos e folhas da área a doença cresceu, provavelmente por infecções oriundas de picnídios formados em ramos (Tabelas 13 a 15). 
Tabela 13. Incidência (\%) de frutos com MPC e intensidade de doença (\%), na variedade 'Valência' sob condições naturais de infecção no ano de 2001

\begin{tabular}{cccc}
\hline Talhão & Tipo de manejo & $\begin{array}{c}\text { Incidência de } \\
\text { frutos }(\%)\end{array}$ & $\begin{array}{c}\text { Intensidade } \\
\text { de doença }(\%)\end{array}$ \\
\hline Com folha & ComFruto & 79,51 & 7,96 \\
& SemFruto & 81,83 & 8,17 \\
\multirow{2}{*}{ Sem folha } & ComFruto & 72,18 & 6,94 \\
& SemFruto & 72,83 & 6,49
\end{tabular}

Tabela 14. Incidência (\%) de frutos com MPC e intensidade de doença (\%), na variedade 'Valência' sob condições naturais de infecção no ano de 2002

\begin{tabular}{cccc}
\hline Talhão & Tipo de manejo & $\begin{array}{c}\text { Incidência de } \\
\text { frutos }(\%)\end{array}$ & $\begin{array}{c}\text { Intensidade } \\
\text { de doença }(\%)\end{array}$ \\
\hline Com folha & ComFruto & 66,40 & 14,26 \\
& SemFruto & 70,30 & 14,58 \\
\multirow{2}{*}{ Sem folha } & ComFruto & 61,76 & 13,82 \\
& SemFruto & 52,23 & 13,51 \\
\hline
\end{tabular}

Tabela 15. Incidência (\%) de frutos com MPC e intensidade de doença (\%), na variedade 'Valência' sob condições naturais de infecção no ano de 2003

\begin{tabular}{cccc}
\hline Talhão & Tipo de manejo & $\begin{array}{c}\text { Incidência de } \\
\text { frutos }(\%)\end{array}$ & $\begin{array}{c}\text { Intensidade } \\
\text { de doença }(\%)\end{array}$ \\
\hline Com folha & ComFruto & 100,00 & 52,18 \\
& SemFruto & 100,00 & 48,74 \\
\multirow{2}{*}{ Sem folha } & ComFruto & 100,00 & 46,21 \\
& SemFruto & 99,97 & 39,52 \\
\hline
\end{tabular}


O desenvolvimento da MPC é influenciado pela disponibilidade de nóculo do patógeno durante a primavera e verão, pelas condições ambientais favoráveis, como calor, período de molhamento e umidade relativa alta e pelo estádio fenológico dos frutos, além do grau de suscetibilidade da variedade cítrica (Timmer et al., 2000).

A retirada de folhas e frutos fez com que, no segundo ano de avaliação (2003), ocorresse uma redução da intensidade da doença, em relação à área onde foram deixados as folhas e frutos. Entretanto, a doença não foi suprimida. Sueda ${ }^{1}$, citado por Calavan (1960), estudando o parasitismo da MPC em Taiwan observou que a doença torna-se sistêmica na planta infectando frutos a partir de lesões encontradas em ramos. Portanto, provavelmente a intensidade de doença na área onde retirourse as folhas e os frutos, deve estar relacionada a infecções ocasionadas a partir de ramos com a doença. Caso esta hipóstese se confirme a poda torna-se-á prática importante para a redução da fonte de inóculo de MPC em pomares.

\subsection{Conclusões}

A eliminação de folhas cítricas em decomposição ou qualquer técnica de manejo que inviabilize a disseminação de ascósporos, como o uso de cobertura morta sobre estas folhas, assim como para a disseminação de conídios, pela antecipação da colheita, a retirada de frutos temporões e poda de limpeza, são práticas culturais que auxiliam na redução do inóculo, sem entretanto abrir mão da utilização do controle químico.

\footnotetext{
${ }^{1}$ SUEDA, H. Experimental studies on the parasitism of the black-spot fungus of citrus.
}

Transctions of Natural History Society of Formosa, v.31, p.416-432, 1941. 


\section{8 aValiação de danos e Perdas CAUSAdos Pela MANCHA PRETA DOS CITROS}

\section{Resumo}

A mancha preta vem causando à cultura dos citros danos qualitativos e quantitativos. O emprego de pulverizações sistemáticas com fungicidas no tratamento da MPC tem-se mostrado prática importante no controle desta doença, reduzindo os sintomas em frutos mesmo em áreas com alta pressão de inóculo. Contudo, não há estimativas precisas das perdas ocasionadas pela doença e, conseqüentemente, da viabilidade econômica dos tratamentos químicos usualmente praticados pelos citricultores em áreas com alta pressão de inóculo. Para isto, foram conduzidos dois experimentos em região com alta pressão de inóculo, onde diferentes tratamentos fungicidas foram aplicados no controle da mancha preta dos citros (MPC) no intuito de produzir variações na intensidade da doença e por conseqüência na produtividade. $\mathrm{O}$ dano causado pela MPC foi estimado a partir dos resultados de produtividade de cada tratamento. Fixourse o melhor tratamento como sendo a máxima produção possível, nas respectivas áreas, e mensurou-se o dano relativo para os outros tratamentos efetuados. Avaliouse a perda causada pela MPC pelo retorno financeiro que cada tratamento aplicado proporcionou, correlacionando-se o custo do tratamento ao ganho econômico gerado pelo incremento na produtividade. Observourse correlação entre a queda prematura de frutos e a intensidade da doença. A maioria dos tratamentos testados incrementou a produção de maneira a gerar receitas ao citricultor. 


\section{Summary}

\section{Evaluation of the Damage and Losses Caused by Citrus Black Spot}

The citrus black spot (CBS) causes qualitative and quantitative damages to citrus industry. The use of systematic fungicide pulverization has been efficient to the control of CBS, reducing the fruit symptoms in strongly affected areas. However, precise estimations about the damages caused by the disease are not disposable, and consequently, the economical viability of this chemical treatment, used by the citrus producers in strongly affected area, have to be evaluated. Two experiments in strongly affected regions were carried out using different fungicide treatments to CBS control, which reduced the intensity of the disease and consequently increased the productivity of the orchards. The damage caused by CBS was estimated using the results of productivity from each treatment. For this, the best treatment was fixed as the maximum possible production in these areas, and the relative damage of the other treatments was measured. Since that the treatment costs was related to profit increasing generated by high productivity, the losses caused by the CBS were evaluated by analysis of profit return that each treatment resulted. The correlation between premature fruit drop and the intensity of the disease was observed. The evaluated treatments resulted in the increasing of the productivity, becoming the orchards more profitable to the citrus producers.

\subsection{Introdução}

A mancha preta vem causando à cultura dos citros danos qualitativos, pelas lesões que a doença provoca em frutos, e danos quantitativos, pela queda prematura de frutos sintomáticos (Klotz, 1978). Os danos qualitativos têm levado a perdas pela depreciação dos frutos no mercado interno e por restringir as exportações a países onde esta doença é considerada como quarentenária A1 (Aguilar-Vildoso et al., 2002). Apesar 
da importância crescente da mancha preta dos citros (MPC) nos pomares brasileiros (Feichtenberger, 1996; Góes, 1998), há poucos dados mostrando os danos causados por essa doença (Fagan \& Góes, 1999). A redução da produtividade leva a perdas cuja determinação é pré-requisito para o controle economicamente vantajoso (Bergamin Filho, 1995b). A terminologia aqui empregada segue Zadoks (1985) que define dano como qualquer redução na qualidade ou quantidade de produção e perda como a redução do retorno financeiro por unidade de área devido à ação de patógenos.

Para o controle da MPC em áreas indenes, as medidas baseadas na exclusão são as mais importantes, principalmente a aquisição de mudas isentas do patógeno. Uma vez que a doença esteja presente em uma área, sua erradicação é praticamente impossível (Feichtenberger, 1996). Neste caso medidas de proteção e terapia mostram-se as mais adequadas.

O emprego de pulverizações sistemáticas com fungicidas no tratamento da MPC, tem-se mostrado eficiente no controle desta doença, reduzindo os sintomas em frutos mesmo em áreas com alta pressão de inóculo (Aguilar-Vildoso et al., 2001; Góes, 2002; Feichtenberger \& Spósito, 2003). Contudo, não há estimativas precisas das perdas provocadas pela doença, nem estudos sobre a viabilidade econômica dos tratamentos químicos usualmente praticados pelos citricultores em áreas com alta pressão de inóculo.

Este trabalho teve como objetivo quantificar os danos e as perdas provocados pela mancha preta dos citros em pomares de laranjeira doce 'Valência', cultivada em região do Estado de São Paulo com alta pressão de inóculo de G. citricarpa e relacionálos com a intensidade de doença.

\subsection{Material e Métodos}

Foram conduzidos dois experimentos em áreas com alta pressão de inóculo, onde diferentes tratamentos fungicidas foram aplicados no controle da mancha preta dos citros (MPC), para produzir variações na intensidade da doença e por conseqüência na produtividade. O "Experimento I" constou de 11 tratamentos, aplicados em plantio 
comercial da variedade de laranjeira doce 'Valência' (Citrus sinensis Osbeck) enxertados em limoeiro 'Cravo' (Citrus limonia Osbeck), plantadas em 1992, com espaçamento de 7 x 4 metros. Os tratamentos aplicados, com respectivas doses e épocas de aplicação estão apresentados no Apêndice 1. O delineamento experimental bi de blocos ao acaso, com 7 plantas por parcela e 4 repetições. No período de pré-colheita foram avaliadas a incidência (porcentagem de frutos sintomáticos por planta) e a severidade da MPC (porcentagem de casca lesionada pela doença), utilizando escala diagramática elaborada por Spósito et al. (2003), em 100 frutos por planta das três plantas centrais de cada parcela nos diferentes tratamentos. O "Experimento II" constou de 15 tratamentos, aplicados em plantio comercial da variedade de laranjeira doce 'Valência' enxertadas em Poncirus trifoliata, plantadas em 1992, com espaçamento de 7 x 4 metros. Os tratamentos aplicados, com respectivas doses e épocas de aplicação estão no Apêndice 2. O delineamento experimental foi de blocos ao acaso, com 18 plantas por parcela (6 plantas na rua em 3 ruas) e 4 repetições, mantendo-se uma rua de plantas como bordadura entre as parcelas. No período de pré-colheita foram avaliadas a incidência e a severidade da MPC, em 100 frutos por planta das 4 plantas centrais da rua central de cada parcela. Quantificoutse nos dois experimentos a produtividade de cada tratamento, pesando os frutos remanescentes nas plantas avaliadas de cada parcela, com o auxílio de dinamômetro.

O dano causado pela MPC foi estimado para cada experimento, a partir dos resultados de produtividade de cada tratamento. Fixourse o melhor tratamento como sendo a máxima produção possível, nas respectivas áreas, e mensurourse o dano relativo para os outros tratamentos efetuados.

Os danos relativos foram linearmente relacionados com a incidência e a severidade da doença de cada tratamento. Os parâmetros $a$ e $b$ obtidos nas equações das retas para os dados de dano relativo em função da severidade e da incidência de mancha preta, para cada área, foram comparados entre si pelo teste $t$. 
Avaliouse a perda causada pela MPC pelo retorno financeiro que cada tratamento aplicado proporcionou, correlacionando-se o custo do tratamento ao ganho econômico gerado pelo incremento na produtividade. Para uniformização dos dados, tanto o custo quanto o incremento na produtividade estimados, foram extrapolados por hectare (ha), fixando um valor médio de 357 plantas (espaçamento de 7 x 4 metros). $\mathrm{O}$ custo por hectare de cada tratamento foi estimado para a aplicação de 4000 litros de calda por hectare (duas bombas/ha), aproximadamente 11 litros de calda por planta, pelos valores praticados por revendas de produtos agropecuários e transformados em dólares (US\$). O incremento na produtividade, medido em caixas de 40,8 kg por hectare, foi estimado subtraindo a produtividade gerada pelo pior tratamento de cada área dos demais tratamentos (caixas excedentes/ha). Supõe-se que as caixas excedentes obtidas estão exclusivamente relacionadas ao tratamento aplicado, uma vez que em toda área foram efetuados os mesmos tratos culturais, exceção feita à aplicação com fungicidas. $\mathrm{O}$ custo de cada caixa excedente foi estimado pelo preço vigente pago por caixa de laranja, também em dólares.

\subsection{Resultados e Discussão}

Os diferentes tratamentos aplicados nos Experimentos I e II proporcionaram uma elevada amplitude da severidade e da incidência de mancha preta. No Experimento I, a severidade variou entre 1,23 e 3,34\% e a incidência entre 53,0 e 92,7\% (Tabela 16) e no Experimento II, a severidade variou entre 0,90 e 7,0\% e a incidência entre 51,8\% e 97,9\% (Tabela 17). Nestas áreas, onde a pressão de inóculo era alta, a maioria dos tratamentos fungicidas propostos (Apêndices 1 e 2) conseguiu reduzir significativamente tanto a porcentagem média da área ocupada pebs sintomas nos frutos, quanto a porcentagem de frutos sintomáticos (Tabelas 16 e 17). 
Tabela 16. Dados de severidade e incidência de mancha preta, o custo dos tratamentos aplicados (custo/ha), a produção colhida (caixas/ha), o excedente de caixas colhidas em relação a testemunha (tratamento 11) (caixas excedentes/ha) e o custo das caixas excedentes, por tratamento aplicado no experimento I

\begin{tabular}{ccccccc}
\hline Tratamento & $\begin{array}{c}\text { Severidade } \\
(\%)^{(\mathrm{i})}\end{array}$ & $\begin{array}{c}\text { Incidência } \\
(\%)^{(\mathrm{i})}\end{array}$ & $\begin{array}{c}\text { Custo/ha } \\
(\mathrm{US} \$)\end{array}$ & $\begin{array}{c}\text { Caixas/ha } \\
(357 \text { plantas })\end{array}$ & $\begin{array}{c}\text { Caixas } \\
\text { Excedentes/ha }\end{array}$ & $\begin{array}{c}\text { Custo caixa } \\
\text { excedente (US\$) }\end{array}$ \\
\hline 1 & $1,23 \mathrm{a}$ & $53,0 \mathrm{a}$ & 254,00 & 1571 & 428 & 0,59 \\
2 & $1,46 \mathrm{ab}$ & $60,0 \mathrm{ab}$ & 222,00 & 1499 & 357 & 0,71 \\
3 & $1,60 \mathrm{ab}$ & $70,2 \mathrm{ab}$ & 254,00 & 1499 & 357 & 0,62 \\
4 & $1,65 \mathrm{ab}$ & $72,5 \mathrm{bc}$ & 152,00 & 1571 & 428 & 0,59 \\
5 & $1,68 \mathrm{ab}$ & $68,7 \mathrm{bc}$ & 174,00 & 1428 & 286 & 0,65 \\
6 & $1,75 \mathrm{ab}$ & $69,2 \mathrm{ab}$ & 254,00 & 1250 & 107 & 1,55 \\
7 & $1,75 \mathrm{ab}$ & $61,5 \mathrm{ab}$ & 186,00 & 1321 & 179 & 0,55 \\
8 & $1,75 \mathrm{ab}$ & $74,5 \mathrm{bc}$ & 98,00 & 1178 & 36 & 3,47 \\
9 & $2,05 \mathrm{ab}$ & $75,5 \mathrm{bc}$ & 166,00 & 1214 & 71 & 2,44 \\
10 & $2,20 \mathrm{~b}$ & $75,2 \mathrm{bc}$ & 124,00 & 1178 & 36 & 4,26 \\
11 & $3,34 \mathrm{c}$ & $92,75 \mathrm{c}$ & 0,00 & 1142 & 0 & \\
\hline
\end{tabular}

(i) diferentes letras nas colunas indicam que os resultados diferem significativamente entre si pelo teste de Tukey $(P<0,05)$.

O dano quantitativo, causado pela queda prematura de frutos, por MPC, foi relacionado ao dano qualitativo, pela incidência e severidade da doença, para os dados dos dois experimentos separadamente (Figura 17). Nos dois experimentos o dano e a intensidade de doença foram linearmente relacionados, tanto para incidência $\left(R^{2}=0,53\right)$ quanto para a severidade $\left(R^{2}=0,59\right)$. As equações lineares ajustadas aos dados dos experimentos I e II geraram parâmetros que não diferiram significativamente pelo teste $t$ (Tabela 18 e Figura 17). Desta forma, um único ajuste foi feito para os dados dois experimentos (Tabela 18). Os resultados mostram que há uma relação direta entre a intensidade da MPC com a queda prematura de frutos. 
Tabela 17 Dados de severidade e incidência de mancha preta, o custo dos tratamentos aplicados (custo/ha), a produção colhida (caixas/ha), o excedente de caixas colhidas em relação a testemunha (tratamento 15) (caixas excedentes/ha) e o custo das caixas excedentes, por tratamento aplicado no experimento II

\begin{tabular}{|c|c|c|c|c|c|c|}
\hline Tratamento & $\begin{array}{c}\text { Severidade } \\
(\%)^{(\mathrm{i})}\end{array}$ & $\begin{array}{c}\text { Incidência } \\
(\%)^{(\mathrm{i})}\end{array}$ & $\begin{array}{l}\text { Custo/ha } \\
\text { (US\$) }\end{array}$ & $\begin{array}{c}\text { Caixas/ha } \\
\text { (357 plantas) }\end{array}$ & $\begin{array}{c}\text { Caixas } \\
\text { excedentes/ha }\end{array}$ & $\begin{array}{c}\text { Custo caixa } \\
\text { excedente (US\$) }\end{array}$ \\
\hline 1 & $0,90 \mathrm{a}$ & $51,8 \mathrm{a}$ & 245,60 & 1334 & 554 & 0,28 \\
\hline 2 & $1,07 \mathrm{a}$ & $66,5 \mathrm{bc}$ & 157,20 & 1523 & 743 & 0,26 \\
\hline 3 & $1,08 \mathrm{a}$ & $58,2 \mathrm{ab}$ & 260,00 & 1247 & 467 & 0,49 \\
\hline 4 & $1,14 \mathrm{ab}$ & $53,8 \mathrm{a}$ & 245,60 & 1240 & 460 & 0,32 \\
\hline 5 & $1,33 a b c$ & $67,4 \quad b c$ & 213,60 & 1349 & 569 & 0,43 \\
\hline 6 & $1,47 \mathrm{abc}$ & 69,9 bcd & 183,60 & 1575 & 795 & 0,31 \\
\hline 7 & $1,53 \mathrm{abc}$ & 70,7 bcd & 192,00 & 1384 & 604 & 0,18 \\
\hline 8 & $1,66 \mathrm{abc}$ & 69,2 bcd & 108,20 & 1574 & 794 & 0,20 \\
\hline 9 & $1,74 \mathrm{abc}$ & $73,8 \quad \mathrm{~cd}$ & 186,60 & 1569 & 789 & 0,27 \\
\hline 10 & $1,76 a b c$ & $72,1 \quad \mathrm{~cd}$ & 165,60 & 1552 & 772 & 0,24 \\
\hline 11 & $2,09 \mathrm{abc}$ & $69,4 \mathrm{bcd}$ & 230,40 & 1233 & 452 & 0,37 \\
\hline 12 & $2,17 a b c$ & 80,7 & 153,60 & 1443 & 663 & 0,28 \\
\hline 13 & $2,66 \quad \mathrm{c}$ & 88,7 & 147,60 & 1217 & 437 & 0,29 \\
\hline 14 & $2,67 \quad \mathrm{c}$ & 81,2 de & 128,40 & 1657 & 877 & 0,32 \\
\hline 15 & $7,00 \quad \mathrm{~d}$ & 97,9 & 0,00 & 780 & 0 & 0 \\
\hline
\end{tabular}

(i) diferentes letras nas colunas indicam que os resultados diferem significativamente entre si pelo teste de Tukey $(P<0,05)$.

Estimar os prejuízos causados por um patógeno constitui-se em um pré-requisito para o desenvolvimento de um programa bem sucedido de controle da doença independentemente do método utilizado (Bergamin Filho, 1996). Nesse processo é importante conhecer o prejuízo que a doença pode ocasionar, assim como o custo do seu controle, para que possa ser tomada uma decisão racional e econômica (Bergamin Filho, 1996). 

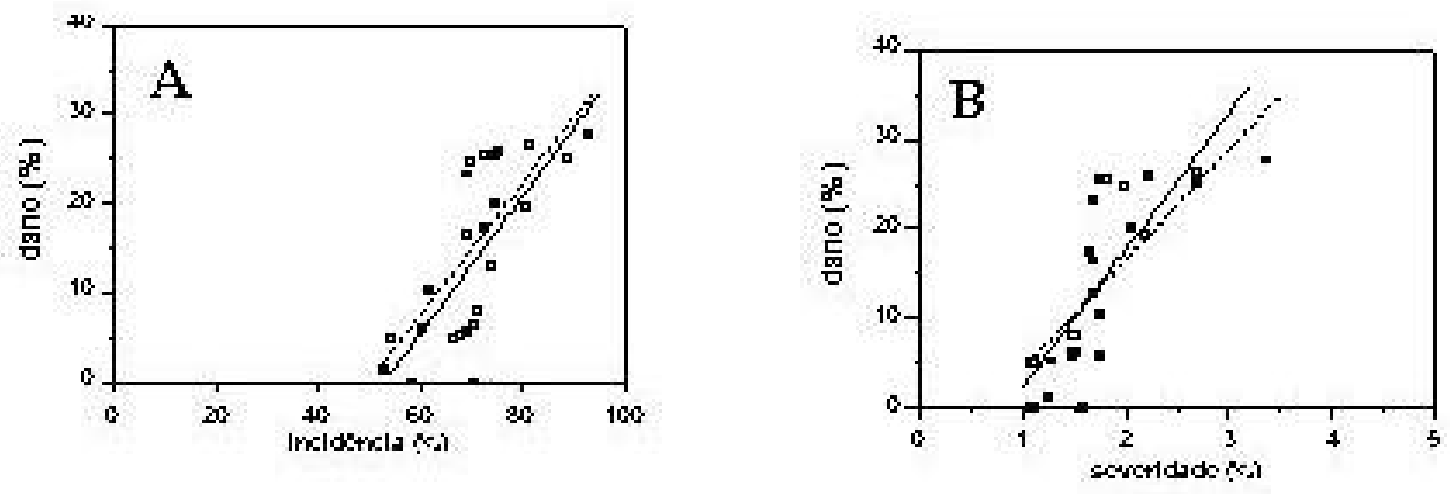

Figura 17 - Dano (\%) ocasionada pela mancha preta dos citros em relação a incidência (A) e a severidade (B) média da doença em frutos por planta, nos tratamentos aplicados nos experimentos I ( e- - e II ( e- - -)

Tabela 18. Teste $t$ para os parâmetros $a$ e $b$ das equações das retas obtidos para os dados de dano em função da severidade e incidência de mancha preta dos citros, e os respectivos coeficientes de determinação $\left(R^{2}\right)$, dos experimentos I e II

\begin{tabular}{lllllll}
\hline Experimento & \multicolumn{2}{l}{ Severidade } & \multicolumn{4}{l}{ Incidência } \\
& $a$ & $b$ & $R^{2}$ & $a$ & $b$ & $R^{2}$ \\
\hline I & $-8,06 \mathrm{a}$ & $12,30 \mathrm{a}$ & 0,43 & $-36,81 \mathrm{a}$ & $0,74 \mathrm{a}$ & 0,52 \\
II & $-12,90 \mathrm{a}$ & $15,63 \mathrm{a}$ & 0,77 & $-40,65 \mathrm{a}$ & $0,77 \mathrm{a}$ & 0,55 \\
I + II & $-10,46$ & 13,91 & 0,59 & $-38,57$ & 0,75 & 0,53 \\
\hline
\end{tabular}

As perdas podem ser calculadas pela redução na produção da cultura, como também pela depreciação dos frutos o que reduz seu preço de mercado. Como este último dado depende das flutuações do mercado, este trabalho ateve-se exclusivamente às perdas causadas por MPC devido à redução na produção da cultura dos citros.

A melhor produção observada nos tratamentos aplicados, denominada "produção possível", não necessariamente pode se mostrar economicamente vantajosa (Bergamin Filho, 1996). Para isto, avaliourse a produção econômica, a qual apresenta o melhor retorno financeiro ao produtor, utilizando como parâmetro o cus to das caixas 
excedentes. Com os dados das Tabelas 16 e 17 correlacionourse o custo do tratamento (custo/ha), o número de caixas colhidas por tratamento (caixas/ha) e o número de caixas colhidas a mais do que a testemunha (caixas excedentes/ha) ao custo destas caixas excedentes (custo caixa excedente). Observourse uma alta correlação $\left(R^{2}=0,92\right)$ apenas entre as caixas excedentes/ha com o custo destas caixas (Figura 18). Pelo resultado obtido observou-se que acima de 300 caixas de 40,8 $\mathrm{Kg}$ a mais por hectare (incremento de, aproximadamente, 0,8 caixas de $40,8 \mathrm{Kg}$ por planta), o custo de cada caixa excedente esteve por volta de US\$ 0,50. Abaixo de 100 caixas de 40,8 $\mathrm{Kg}$ a mais por hectare (incremento de, aproximadamente, 0,3 caixas de 40,8 $\mathrm{Kg}$ por planta), o custo de cada caixa excedente apresentou valores acima de US\$ 1,50 (Figura 18).

Os resultados de danos demostraram que a intensidade de mancha preta influenciou na queda prematura dos frutos cítricos e que os tratamentos químicos empregados mostraramse viáveis quando o número de caixas excedentes colhidas por hectare sobrepôs a 100 caixas de 40,8 Kg. A viabilidade de um tratamento, entretanto, está diretamente relacionado ao custo de produção e ao preço que o produto obtém no mercado.

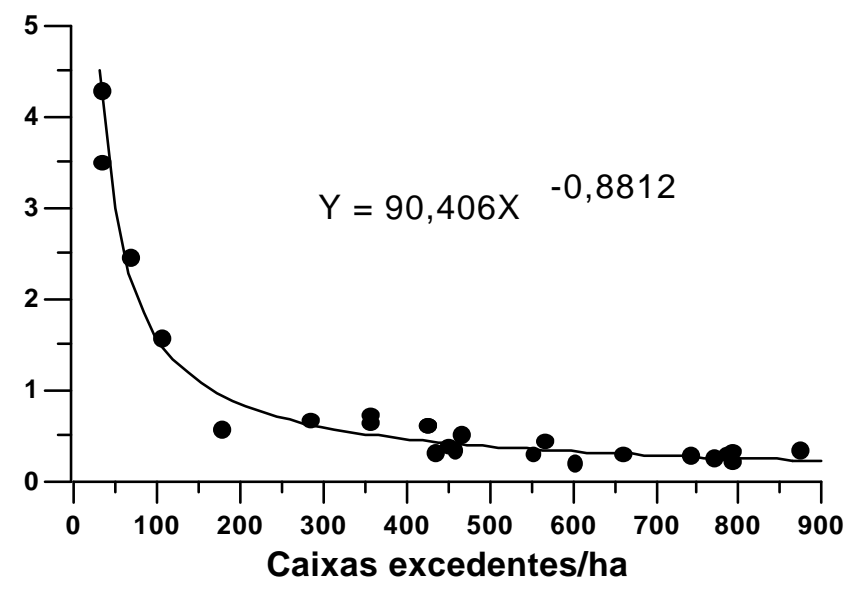

Figura 18 - Custo do tratamento químico para o controle da MPC por caixas de laranja $(40,8 \mathrm{Kg})$ excedentes comparados com o tratamento sem controle químico (custo da caixa excedente) em relação ao número de caixas de laranja colhidas a mais por tratamento em relação ao tratamento sem controle químico 
Frutos cítricos produzidos para o mercado interno de fruta fresca, tiveram um preço médio, nos últimos 5 anos, de US\$ 5,40/ caixa enquanto que nos últimos dois anos a indústria pagou um preço médio de US\$3,00, para a caixa de 40,8 Kg de laranja (FNP Consultoria \& Comércio, 2003). Os custos operacionais para se produzir citros em São Paulo gira em torno de US\$ 1,27 por caixa de 40,8 Kg, (FNP Consultoria \& Comércio, 2003). Subtraindo os custo operacional de produção (US\$ 1,27) do preço pago pela indústria (US\$ 3,00), o citricultor tem um lucro líquido médio de US\$1,73. Valores de custo para o tratamento de MPC, medidos por caixas excedentes, acima do lucro líquido significam prejuízos ao citricultor (Tabela 16 e 17).

Os tratamentos aplicados tanto no experimento I quanto no II conseguiram reduzir significativamente a doença, o que ocasionou a uma redução de danos causados por queda prematura de frutos. A maioria dos tratamentos aplicados mostroutse economicamente viável, em áreas com alta pressão de MPC. Estes resultados são importantes para produtores que comercializam seus frutos com a indústria de suco cítrico concentrado, entretanto, para o mercado de fruta fresca, os níveis mínimos observados nos dois experimentos, tanto para a incidência quanto para a severidade da MPC não obtiveram performance que possibilitassem a comercialização neste mercado. Portanto, em áreas com alta pressão de inóculo, para a produção de frutos para o mercado de fruta fresca, torna-se necessário o incremento no número de aplicações em conjunto com outras técnicas de manejo visando reduzir de maneira adequada a intensidade da MPC.

\subsection{Conclusões}

A intensidade de mancha preta influencia na queda prematura dos frutos cítricos e os tratamentos químicos atualmente recomendados para o controle da mancha preta dos citros, em área com alta pressão de inóculo, visando a produção de frutos para a indústria, são rentáveis. 


\section{CONCLUSÕES GERAIS}

A mancha preta dos citros (MPC) é uma doença de grande importância, principalmente para citricultores que comercializam no mercado de fruta fresca, pois as lesões causadas depreciam os frutos e restringem as exportações. A intensidade da doença além de prejudicar a aparência dos frutos, está diretamente relacionada à queda prematura dos frutos cítricos, reduzindo, portanto, a produtividade.

Não é possível avaliar a severidade em função da incidência da doença, uma vez que para uma mesma incidência obtém-se diferentes severidades. Isto faz com que seja necessário avaliar as duas variáveis, a primeira importante para frutos para indústria, uma vez que a severidade correlaciona-se à queda prematura de frutos, e a segunda, importante para o mercado de fruta fresca, pois os sintomas depreciam os frutos. A escala diagramática desenvolvida nesta tese mostrou-se uma ferramenta de fácil uso e com resultados satisfatórios para avaliação da severidade da doença. As variedades 'Hamlin', 'Pera' e 'Valência', que possuem diferentes épocas de maturação, precoce, meia estação e tardia, respectivamente, apresentam o mesmo grau de suscetibilidade à MPC. A precocidade dos sintomas na variedade 'Hamlin' assim como a maior intensidade de doença na variedade 'Valência' estão relacionadas ao estádio fenológico em que os frutos ficam expostos a condições ambientais favoráveis à expressão dos sintomas. Plantas doentes em uma área assim como frutos sintomáticos em plantas ficam agregados mostrando elevada importância dos mecanismos de dispersão a curtas distâncias. A agregação de frutos sintomáticos com MPC em plantas, denota a elevada importância relativa dos conídios no incremento da doença. Padrão espacial agregado da MPC em plantas no talhão e em frutos nas plantas, indicam a necessidade de medidas de sanitização no manejo da doença. A supressão de ascósporos, por meio da retirada de 
folhas, assim como a de conídios formados em frutos, pela colheita antecipada, em áreas com alta intensidade de doença, reduzem o inóculo e contribuem para a redução da intensidade da MPC, entretanto, por si só não são suficientes para o controle adequado da doença. O controle químico usualmente aplicado no campo é prática importante, reduzindo de maneira eficaz os danos quantitativos, causados pela queda prematura de frutos sintomáticos, entretanto, não é capaz de reduzir a intensidade de doença visando produzir frutos para o mercado de fruta fresca, em áreas com alta pressão de inóculo. $\mathrm{O}$ número de aplicações deve ser revisto no intuito de minimizar os danos qualitativos observados no campo. Em áreas de citros onde a produção visa o mercado de fruta fresca, a quantificação da incidência de plantas doentes deve ser feita avaliando todas as plantas da área, uma vez que a MPC interfere na qualidade visual do fruto. Em áreas onde a produção visa a indústria de suco concentrado, pode-se adotar um esquema de amostragem aleatória dentro da área, pois a MPC não interfere na qualidade interna dos frutos. 


\section{REFERÊNCIAS BIBLIOGRÁFICAS}

AGUILAR-VILDOSO, C.I.; FEICHTENBERGER, E.; MORAES, M.R.; SPÓSITO, M.B.; SCHINOR, E.H. Avaliação de tratamentos fungicidas no controle de mancha preta (Guignardia citricarpa) em laranjeira 'Pera' de diferentes idades. Summa Phytopathologica, v.25, n.1, p.51, 1999.

AGUILAR-VILDOSO, C.I.; RIBEIRO, J.G.B.; FEICHTENBERGER, E.; GOES, A.; SPÓSITO, M.B. Manual técnico de procedimentos da mancha preta dos citros. Brasília: MAPA/SDA/DDIV, 2002. 72p.

ALCOBA, N.J.; VIGIANI, A.R.; BEJARANO, N.V.; ALVAREZ, S.E.; SERRANO, M.A.; BONILLO, M.C. La Mancha Negra de los Citricos. Jujuy: Ed. Universidad Nacional de Jujuy, 2000. 56p.

AMORIM, L. Avaliação de doenças. In: BERGAMIN FILHO, A., KIMATI, H.; AMORIM, L. (Ed.). Manual de Fitopatologia. São Paulo: Ceres, 1995. cap.32, p.647-671.

AYLOR. D.E. The role of intermittent wind in the dispersal of plant pathogens. Annual Review of Phytopathology, v.28, p.73-92, 1990. 
BAAYEN, R.P.; BONANTS, P.J.; VERKLEY, G.; CAROLL, G.C.; VAN DER AA, H.A.; DE WEERDT, M; VAN BROUWERSHAVEN, I.R.; SCHUTTE, G.C.; MACCHERONI JÚNIOR., W.; GLIENKE DE BLACO, C.; AZEVEDO, J.L. Nopathogenic isolates of the citrus black spot fungus, Guignardia citricarpa, identified as a cosmopolitan endophyte of woody plants, G. mangiferae (Phyllosticta capitalensis)". Phytopathology, v.92, n.5, p.464-477, 2002.

BALDASSARI, R.B. Influência de frutos sintomáticos de uma safra na incidência da Guignardia citricarpa na safra subsequente e período de suscetibilidade de frutos de laranjeira 'Natal' e 'Valência'. Jaboticabal, 2001. 60p. Dissertação (M.S.) Faculdade de Ciências Agrárias e Veterinárias, Universidade Estadual Paulista "Júlio de Mesquita Filho".

BERGAMIN FILHO, A. Avaliação de danos e perdas In: BERGAMIN FILHO, A.; KIMATI, H.; AMORIM, L. (Ed.). Manual de Fitopatologia. São Paulo: Ceres. 1995a. cap.33, p.672-690.

BERGAMIN FILHO, A. Curvas de progresso da doença, In: BERGAMIN FILHO, A.; KIMATI, H.; AMORIM, L. (Ed.). Manual de Fitopatologia. São Paulo: Ceres, 1995b. cap. 30, p.602-626.

BERGAMIN FILHO, A.; AMORIM, L. Doenças de plantas tropicais: epidemiologia e controle econômico. São Paulo: Ceres, 1996. 299 p.

BERGAMIN FILHO, A.; HAU, B.; AMORIM, L.; LARANJEIRA, F.F. Análise espacial de epidemias. Revisão Anual de Patologia de Plantas, v.10, p.155-218, 2002. 
CAMPBELL, C.L.; MADDEN, L.V. Introduction to Plant Disease Epidemiology. New York: John Wiley, 1990. 532p.

CARDOSO FILHO, J.A. Efeito de extratos de albedo de laranja (Citrus sinensis) e dos indutores de resistência ácido salicílico, acilbenzolar-s-metil e Saccharomyces cerevisiae no controle de Phyllosticta citricarpa (teleomorfo: Guignardia citricarpa). Piracicaba, 2003. 125p. Tese (Doutorado) - Escola Superior de Agricultura “Luiz de Queiroz”, Universidade de São Paulo.

CHAREST, J.; DEWDNEY, M.; PAULITZ, T.; PHILION, V.; CARISSE, O. Spatial distribution of Venturia inaequalis airborne ascospores in orchards. Phytopathology, v.92, p.769-779, 2002.

CORNELL, J.A.; BERGER, R.D. Factors that influence the coefficient of determination in single linear and nonlinear models. Phytopathology, v.77, p.63-70, 1987.

COSTA, H.; VENTURA, J.A.; ARLEU, R.J.; AGUILAR-VILDOSO, C.I. Ocorrência da pinta preta (Guignardia citricarpa) em citros no Estado do Espírito Santo. Fitopatologia Brasileira, v.28, p.205, 2003. Suplemento.

CZERMAINSKI, A.B.C. Generalização de um índice de intensidade de infecção em experimentos de avaliação de doenças em plantas. Pesquisa Agropecuária Brasileira, v.34, p.1545-1556, 1999.

DAVIES, F.S.; ALBRIGO, L.G. Cítricos. Zaragoza: Ed. Acribia, 1999. 283p.

DHANVATARI, B.N.; DIRKS, V.A. Bacterial stem rot of greenhouse tomato: etiology, spatial distribution, and the effect of high humidity. Phytopathology, v.77, p.1457$1463,1987$. 
DILLARD, H.R.; SEEM, R.C. Incidence-severity relationships for common maize rust on sweet corn. Phytopathology, v.80, p.842-846, 1990.

DOIDGE, E.M. Some diseases of citrus prevalent in South Africa. South African Journal of Science., v.26, p.320-325, 1929.

DRAPER, N.R.; SMITH, H. Applied regression analysis. New York: John Wiley, 1998. 706p.

EDWARDS, J.; TAYLOR, P.A.; PARBERY, D.G.; HALLORAN, G.M. Peppermint rust in Victoria: the incidence-severity relationship and its implication for the development of an action threshold. Australian Journal of Agricultural Research, v.51, p.91-95, 2000.

FAGAN, C.; GÓES, A. Efeito da severidade da mancha preta dos frutos cítricos causada por Guignardia citricarpa na queda de frutos de laranja 'Natal'. Fitopatologia Brasileira, v.24, p.282, 1999.

FAGAN, C.; GÓES, A. Efeito da mancha preta dos frutos cítricos causada por Guignardia citricarpa nas características tecnológicas do suco de frutos de laranjeira 'Natal'e 'Valência'. Summa Phytopathologica, v.26, n.1, p.122, 2000.

FEICHTENBERGER, E. Mancha-preta dos citros no Estado de São Paulo. Laranja, v.17, p.93-108, 1996.

FEICHTENBERGER, E.; SPÓSITO, M.B. Tratamentos fungicidas no controle de mancha preta (Guignardia citricarpa) em laranjeiras 'Valência'. Fitopatologia Brasileira, v.28, p.310, 2003. Suplemento. 
FEICHTENBERGER, E.; MULLER, G.W.; GUIRADO, N. Doenças dos citros. In: KIMATI, H.; AMORIM, L.; BERGAMIN FILHO, A.; CAMARGO, L.E.A.; REZENDE, J.A.M. (Ed.). Manual de Fitopatologia. São Paulo: Ceres, 1997. cap. 25, p.261-296.

FEICHTENBERGER, E.; SPÓSITO, M.B.; VIANNA, J.H.T. Tratamentos fungicidas no controle de mancha preta (Guignardia citricarpa) em laranjeira 'Valência'. Summa Phytopathologica, v.26, n.1, p.199, 2000.

FITT, B.D.L.; McCARTNEY, H.A.; WALKLATE, P.J. The role of rain in dispersal of pathogen inoculum. Annual Review of Phytopathology, v.27, p.241-270, 1989.

FNP CONSUlTORIA \& COMÉRCIO. Agrianual 2002: Anuário da Agricultura Brasileira. São Paulo: Ed. Argos, 2002. 536p.

FNP CONSUlTORIA \& COMÉRCIO. Agrianual 2003: Anuário da Agricultura Brasileira. São Paulo: Ed. Argos, 2003. 544p.

FUNDECITRUS. Manual de pinta preta, Araraquara: Fundecitrus, 2003. 7p.

GILLIGAN, C.A. Statistical analysis of the spatial pattern of Botrytis fabae on Vicia faba: a methodological study. Transactions of the British Mycology Society, v.79, p.193-200, 1982.

GOES, A. Controle da mancha-preta dos frutos cítricos. Laranja, v.9, p.305-320, 1998.

GÓES, A. Efeito da combinação de fungicidas sistêmicos e protetores no controle da mancha preta dos frutos cítricos causada por Guignardia citricarpa. Summa Phytopathologica, v.28, n.1, p.9-13, 2002. 
GOES, A.; FEICHTENBERGER, E. Ocorrência da mancha preta causada por Phyllosticta citricarpa (Guignardia citricarpa) em pomares cítricos do Estado de São Paulo. Fitopatologia Brasileira, v.15, p.73-75, 1993.

GOES, A.; GRAÇA, J.; MONTEIRO DE BARROS, J.C.S.; PINHEIRO, J.E. Controle da pinta preta em frutos de tangerina 'Rio' (Citrus deliciosa) ocasionada por Phyllosticta citricarpa (Guignardia citricarpa). Fitopatologia Brasileira, v.15, n.1, p.73-75, 1990.

GOTTWALD, T.R.; GIDTTI, F.B.; SANTOS, J. M.; CARVALHO, A. C. Preliminary spatial and temporal analysis of citrus variegated chlorosis (CVC) in São Paulo, Brazil. In: TWELFTH IOCV CONFERENCE, Riverside, 1993. Anais. Riverside: International Organization of Citrus Virologists, 1993. p.327-335.

GOTTWALD, T.R.; CAMBRA, M.; MORENO, P.; CAMARASA, E.; PIQUER, J. Spatial and temporal analyses of citrus tristeza virus in eastern Spain. Phytopathology, v.86, p.45-55, 1996.

HORSFALL, J.G.; BARRAT, R.W. An improved grading system for measuring plant diseases. Phytopathology, v.35, p.655, 1945.

HSIANG, T.; MA, X. L.; ZHOU, T. Temporal and spatial analyses of genetic diversity in Venturia inaequalis assessed by RAPD markers. Canadian Journal of Plant Pathology, v.22, p.186, 2000.

HUGHES, G.; MADDEN, L.V. Aggregation and incidence of disease. Plant Pathology, v.41, p.657-660, 1992.

HUGHES, G.; MADDEN, L.V.; MUNKVOLD, G.P. Cluster sampling for disease incidence data. Phytopathology, v.86, p.132-137, 1996. 
HUBER, L.; MADDEN, L.V.; FITT, B.D.L. Rain-splash and spore dispersal: a physical perspective. In: JONES, D. G. (Ed.). The epidemiology of plant diseases. Dordrecht: Kluver, 1998.p.348-370.

JONES, D.G. The epidemiology of plant diseases. Dordrecht: Kluwer, 1998b. 460 p.

JORGE, L.A.C. Siarcs 3.0 para Windows: manual do usuário. São Carlos: Instrumentação Agropecuária. Embrapa, 1996. 30p.

KAPLAN, J.D. Dispersal gradients and deposition efficiency of Venturia inaequalis ascospores and their relationship to lesion densities. Durbham, 1986. 198p. Thesis (Ph. D.) - University of New Hampshire.

KEINATH, A.P.; FARNHAM, M.W. Differential cultivars and criteria for evaluating resistance to Rhizoctonia solani in seedling Brassica oleracea. Plant Disease, v.81, p.946-952, 1997.

KENKEL, N.C. Pattern of self-thinning in Jack Pine: testing the random mortality hypothesis. Ecology, v.69, p.1017-1024, 1988.

KIELY, T.B. Preliminary studies on Guignardia citricarpa spp.: the ascigerous stage of Phoma citricarpa and its relation to blck spot of citrus. Proceedings of the Linnean Society of New SouthWales, v.93, p.249-292, 1948.

KIELY, T.B. Black spot of citrus in New South Wales coastal orchards. The Agricultural Gazette, v.1, p.17-20, 1949. 
KIMATI, H.; BERGAMIN FILHO, A. Princípios gerais de controle. In: BERGAMIN FILHO, A.; KIMATI, H.; AMORIM, L. (Ed.). Manual de Fitopatologia. São Paulo: Ceres, 1995. cap.34, p.692-709.

KLOTZ, L.J. Fungal, bacterial and nonparasitic diseases and injuries originating in the seedbed, nursery and orchard. In: REUTHER, W., CALAVAN, E. C.; CARMAN, G. E. (Ed.) The citrus industry. California: University of California, 1978. p. 1-66.

KOTZÉ, J. M. Studies on the black spot disease of citrus caused by Guignardia citricarpa Kiely with particular reference to its epiphytology and control at Lebata. Pretoria, 1963. 147p. Thesis (Ph.D.) - University of Pretoria.

KOTZÉ, J.M. Epidemiology and control of citrus black spot in South Africa. Plant Disease, v.65, p.945-950, 1981.

KOTZÉ, J.M. Black spot. In: WHITESIDE, J.O.; GARNSEY, S.M.; TIMMER, L.W. (Ed.). Compendium of Citrus Diseases. St. Paul: APS Press, 1988. p. 10-12.

KOTZÉ, J.M. History and epidemiology of citrus black spot in South Africa. In: INTERNATIONAL CITRUS CONGRESS, 8., Sun City, 1996. Anais. Sun City: ISC, 1996. p.1296-1299.

KRANZ, J. Comparasion of epidemics. Annual Review of Phytopathology, v.12, p.355-374, 1974.

KRANZ, J. Epidemics of plant diseases. Mathematical analysis and modeling. Berlin: Springer, 1990. 268 p.

KRANZ, J. Epidemiologie der Pflanzenkrankheiten Eine Einführung. Stuttgart: Ulmer, 1996. $413 \mathrm{p}$. 
KRANZ, J.; ROTEM, J. Experimental techniques in plant disease epidemiology. Berlin: Springer, 1988. 299 p.

LALANCETTE, N.; ROBISON, D.M. Effect of fungicides, application timing, and canker removal on incidence and severity of constriction canker of peach. Plant Disease, v.86, p.721-728, 2002.

MADDEN, L.V. Dynamic nature of within-field disease and pathogen distributions. In: JEGER, M.J. (Ed.). Spatial Components of Plant Disease Epidemics. New Jersey: Prentice-Hall, 1989. p.96-126.

MADDEN, L.V. Rainfall and dispersal of fungal spores. In: ANDREWS, J.H.; TOMMERRUP, I. (Ed.). Advances in plant pathology. London: Academic Press, 1992. v.8. p.39-79.

MADDEN, L.V.; HUGHES, G Plant disease incidence: distributions, heterogeneity, and temporal analysis. Annual Review of Phytopathology, v.33, p.529-564, 1995.

MAZZUZ, C.F. Calidad de Frutos Citricos. Manual para su Gestión desde la Recolección hasta la Expedición. Reus: Ed. Horticultura, 1996. 317p.

MCONIE, K.C. Orchard development and discharge of ascospores of Guignardia citricarpa and the onset of infection in relation to the control of citrus black spot. Phytopathology, v.54, p.1448-1453, 1964a.

MCONIE, K.C. Source of inoculum of Guignardia citricarpa, the citrus black spot pathogen. Phytopathology, v.54, p.64-67, 1964b. 
MCONIE, K.C. Source of infection for black spot of citrus. The South African Citrus Journal, June, p.5-9, 1965.

MCONIE, K.C. Germination and infection of citrus by ascospores of Guignardia citricarpa in relation to control of black spot. Phytopathology, v.57, p.743-746, 1967.

NETER, J.; KUTNER, M.H.; NACHTSHEIM, C.J.; WASSERMAN, W. Applied Linear Statistical Models. 4. ed. Chicago: Irwin, 1996. 408 p.

NICOT, P.C.; ROUSE, D.I.; YANDELL, B.S. Comparison of statistical methods for studying patterns of soilborne plant pathogens in the field. Phytopathology, v.74, p.1399-1402, 1984.

NUTTER JUNIOR, F.W.; WORAWITLIKIT, O. Disease.Pro: A computer program for evaluating and improving a person ability to assess disease proportion. Phytopathology, v.79, p.1135, 1989.

NUTTER JUNIOR, F.W.; SCHULTZ, P.M. Improving the accuracy and precision of disease assessments: selection of methods and use of computer-aided training programs. Canadian Journal of Plant Pathology, v.17, p.174-184, 1995.

NUTTER JUNIOR, F.W.; TENG, P.S.; SHOKES, F.M. Disease assessment terms and concepts. Plant Disease, v.75, p.1187-1188, 1991.

NUTTER JUNIOR, F .W.; MILLER, D.L.; WEGULO, S.N. Do standard diagrams improve the accuracy and precision of disease assessment. In: INTERNATIONAL CONGRESS OF PLANT PATHOLOGY, 7., Edinburgh, 1998. Anais. Edinburgh: ISPP, 1998, p.2116. 
PEDGLEY, D.E. Long distance transport of spores. In: LEONARD, K.J.; FRY, W.E. (Ed.). Plant disease epidemiology. Population dynamics and management. New Yok: MacMillan, 1986. p.346-365.

RABBINGE, R.; WARD, S.A.; VAN LAAR, H.H. Simulation and systems management in crop protection. Wageningen: Pudoc, 1989. 420 p.

REIS, R.F. Influência dos fatores climáticos na produção e liberação de ascósporos de Guignardia citricarpa em pomares de laranjeiras 'Natal' e 'Valência". Jaboticabal, 2002. 87p. Dissertação (M.S.) - Faculdade de Ciências Agrárias e Veterinárias, Universidade Estadual Paulista "Júlio de Mesquita Filho".

RIPLEY, B.D. The second-order analysis of stationary point processes. Journal of Applied Probability, v.13, p.255-266, 1976.

RIPLEY, B.D. Spatial statistic. New York: John Wiley, 1981. 272p.

ROBBS, C.F. A mancha preta dos frutos cítricos Phyllosticta citricarpa): ameaça à citricultura paulista. Laranja, v.11, p.87-95, 1990.

ROBBS, C.F.; BITTENCOURT, A.M. A mancha preta dos frutos: um dos fatores limitantes à produção citrícola do Estado do Rio de Janeiro. Guaratiba: EMBRAPA/CTAA, n.19, p.1-5, 1995. (Comunicado Técnico)

ROBBS, C.F.; PIMENTEL, J.P.; RIBEIRO, R.L. A mancha preta dos citros causada por Phoma citricarpa. Fitopatologia Brasileira, v.5, p.455, 1980. 
ROUSE, D.I.; MACKENZIE, D.R.; NELSON, R.R.; ELLIOTT, V.J. Distribution of wheat powdery mildew incidence in field plots and relationship to disease severity. Phytopathology, v.71, p.1015-1020, 1981.

ROWLINGSON, B.; DIGGLE, P. Splancs: spatial point pattern analysis code in S-Plus. Computers and Geoscience, v.19, p.627-655, 1993.

SCHINOR, E.H. Resistência de clones de laranjeira 'Pera' e variedades afins à mancha preta dos citros. Piracicaba, 2001. 90p. Dissertação (Mestrado) - Escola Superior de Agricultura “Luiz de Queiroz”, Universidade de São Paulo.

SCHUH, W. Influence of tillage systems on the disease intensity an spatial pattern of Septoria leaf blotch. Phytopathology, v.80, p.1337-1340, 1990.

SCHUTTE, G.C.; KOTZÉ, J.M. Grass mulching as part of an integrated control programme for the control of citrus black spot. Citrus Journal, v.7, p.18-20, 1997.

SCHUTTE, G.C.; BEETON, K.V ; KOTZÉ, J.M. Rind stippling on Valencia oranges by copper fungicides used for control of citrus black spot in South Africa. Plant Disease, v.81, p.851-854, 1997.

SEEM, R.C. Disease incidence and severity relationships. Annual Review of Phytopathology, v.22, p.133-150, 1984.

SHAW, M.W.; ROYLE, D.J. Airborne inoculum as a major source of Septoria tritici (Mycosphaerella graminicola) infections in the winter wheat crops in the U.K. Plant Pathology, v.38, p.35-43, 1989. 
SILVA, M.B., VALE, F.X.R., ZAMBOLIM, L.; PAULA JUNIOR, T.J. Caracterização da curva de progresso da ferrugem do feijão em diferentes épocas de plantio em Viçosa, MG. Fitopatologia Brasileira, v.23, p.139-142, 1998.

SILVA-ACUÑA, R.; MAFFIA, L.A.; ZAMBOLIM, L.; BERGER, R.D. Incidenceseverity relationships in the pathosystem Coffea arabica-Hemileia vastatrix. Plant Disease, v.83, p.186-188, 1999.

SMITH, J.L. A study of the effect of various disease control programs on spore releases of the citrus black spot pathogen Guignardia citricarpa. In: INTERNATIONAL CITRUS CONGRESS, 8., Sun City, 1996. Anais. Sun City: ISC, 1996. p.351-352.

SPÓSITO, M.B.; AGUILAR-VILDOSO, C.I.; MORAES, M.R.; FEICHTENBERGER, E. Época de aplicação de fungicida no controle de mancha preta (Guignardia citricarpa) em laranjeira 'Pera'. Summa Phytopathologica, v.26, n.1, p.119, 2000.

SPÓSITO, M.B.; AGUILAR-VILDOSO, C.I.; FEICHTENBERGER, E.; MORAES, M.R.; RUBIM, C.A. Avaliação de tratamentos fungicidas no controle da mancha preta em frutos de laranjeira 'Natal'. Fitopatologia Brasileira, v.24, p.334, 1999.

SPÓSITO, M.B.; AMORIM, L.; BELASQUE JUNIOR, J.; BASSANESI, R.B.; AQUINO, R. Elaboração e validação de escala diagramática para avaliação da severidade da mancha preta em frutos cítricos. Fitopatologia Brasileira, v.28, p.231, 2003. Suplemento.

SPÓSITO, M. B.; BASSANEZI, R. B.; FARIAS, P. R.; LARANJEIRA, F. F.; LOURENÇO, S. A.; AMORIM, L.; BERGAMIN FILHO, A. Spatial pattern of citrus black spot in Brazil. In: INTERNATIONAL WORKSHOP ON PLANT DISEASE EPIDEMIOLOGY, 8., Ouro Preto, 2001. Anais. Ouro Preto: ISPP, 2001. p.33. 
TAYLOR, L.R. Aggregation, variance and the mean. Nature, v.189, p.732-735, 1961.

TENG, P.S. Validation of computer models of plant disease epidemics: a review of philosophy and methodology. Zeitschrift für Pflanzenkrankheiten und Pflanzenschutz, v.88, p.455-459, 1981.

TIMMER, L.W. Diseases of fruit and foliage. In: TIMMER, L.W.; DUNCAN, L.W. (Ed.). Citrus Health Management. Florida: APS Press, 1999. p.107-123.

TIMMER, L.W.; GARNSEY, S.M.; GRAHAM, J.H. Compendium of Citrus Diseases. 2. ed., St. Paul: APS Press, 2000. 92p.

TORMELIN, J.R.; HOWELL, T.A. Distrain: a computer program for training people to estimate disease severity on cereal leaves. Plant Disease, v.72, p.455-459, 1988.

TURECHEK, W.W.; MADDEN, L.V. Spatial pattern analysis of strawberry leaf blight in perennial production systems. Phytopathology, v.89, p.421-433, 1999.

UPTON, G.; FINGLETON, B Spatial data analysis by example. Point pattern and quantitative data. Chichester: Wiley, 1985. 409 p.

VAN LEEUWEN, G.C.M.; STEIN, A.; HOLB, I.; JEGER, M.J. Yield loss in apple caused by Monilinia fructigena (Aderh. \& Ruhl.) Honey, and spatio-temporal dynamics of disease development. European Journal of Plant Pathology, v.106, p.519-528, 2000. 
VANDERPLANK, J. E. Spread of plant pathogens in space and time. In: GREGORY, P.H.; MONTEITH, J.L. (Ed.). Airborne microbes. Cambridge: Cambridge University Press, 1967. p.227-247.

VANDERPLANK, J.E. Plant diseases: epidemics and control. New York: Academic Press, 1963. 349 p.

WAGGONER, P.E.; RICH, S. Lesion distribution, multiple infection, and logistic increase of plant disease. Proceedings of the National Academy of Science, v.78, p.3292-3295, 1981.

WHITESIDE , J.O.; GARNSEY, S.M.; TIMMER, L.W. Compendium of citrus diseases. St. Paul: APS Press, 1993. 80p.

XU, X.; MADDEN, L.V. Incidence and density relationship of powdery mildew on apple. Phytopathology, v.92, p.1005-1014, 2002.

ZADOKS, J.C. On the conceptual basis of crop loss assessment the threshould theory. Annual Review of Phytopathology, v.23, p.455-473, 1985.

ZADOKS, J.C. Reflections on space, time, and diversity. Annual Review of Phytopathology, v.37, p.1-17, 1999.

ZADOKS, J.C.; SCHEIN, R.D. Epidemiology and plant disease management. New York: Oxford University Press, 1979. 427 p. 


\section{APÊNDICES}


Apêndice 1. Tratamentos fungicidas, doses e épocas de aplicação, utilizados no "Experimento I", no controle da mancha preta dos citros em pomar de laranjeira 'Valência', 2001

\begin{tabular}{|l|c|c|c|c|c|c|c|c|}
\hline \multicolumn{1}{|c|}{ Tratamentos } & Dose & \multicolumn{5}{c|}{ Aplicações* } \\
\cline { 5 - 9 } & (g i. a./100L) & 1 & 2 & $3^{\mathrm{a}}$ & $4^{\mathrm{a}}$ & $5^{\mathrm{a}}$ & $6^{\mathrm{a}}$ & $7^{\mathrm{a}}$ \\
\hline 1 Hidróxido de cobre + OME** & $90+0,5 \%$ & $\mathrm{X}$ & $\mathrm{X}$ & $\mathrm{X}$ & $\mathrm{X}$ & & & \\
Carbendazim+Hidróxido de cobre+OME & $25+90+0,5 \%$ & & & & & $\mathrm{X}$ & \\
\hline 2 Hidróxido de cobre + OME & $90+0,25 \%$ & $\mathrm{X}$ & $\mathrm{X}$ & & $\mathrm{X}$ & & $\mathrm{X}$ & \\
Carbendazim+Hidróxido de cobre+OME & $25+90+0,25 \%$ & & & $\mathrm{X}$ & & & & \\
\hline 3 Hidróxido de cobre + OME & $90+0,5 \%$ & $\mathrm{X}$ & $\mathrm{X}$ & & $\mathrm{X}$ & & $\mathrm{X}$ & \\
Carbendazim+Hidróxido de cobre+OME & $25+90+0,5 \%$ & & & $\mathrm{X}$ & & & & \\
\hline 4 Hidróxido de cobre + OME & $90+0,25 \%$ & $\mathrm{X}$ & $\mathrm{X}$ & $\mathrm{X}$ & $\mathrm{X}$ & & & \\
\hline 5 Hidróxido de cobre + OME & $90+0,25 \%$ & $\mathrm{X}$ & $\mathrm{X}$ & & $\mathrm{X}$ & & & \\
Carbendazim+Hidróxido de cobre+OME & $25+38,25+0,25 \%$ & & & $\mathrm{X}$ & & & & \\
\hline 6 Hidróxido de cobre + OME & $90+0,5 \%$ & $\mathrm{X}$ & $\mathrm{X}$ & & & $\mathrm{X}$ & & $\mathrm{X}$ \\
Carbendazim+Hidróxido de cobre+OME & $25+90+0,5 \%$ & & & $\mathrm{X}$ & & & & \\
\hline 7 Hidróxido de cobre + OME & $38,25+0,25 \%$ & $\mathrm{X}$ & $\mathrm{X}$ & & $\mathrm{X}$ & & $\mathrm{X}$ & \\
Carbendazim+Hidróxido de cobre+OME & $25+38,25+0,25 \%$ & & & $\mathrm{X}$ & & & & \\
\hline 8 Hidróxido de cobre + OME & $38,25+0,25 \%$ & $\mathrm{X}$ & $\mathrm{X}$ & $\mathrm{X}$ & $\mathrm{X}$ & & & \\
\hline 9 Hidróxido de cobre + OME & $38,25+0,5 \%$ & $\mathrm{X}$ & $\mathrm{X}$ & & $\mathrm{X}$ & & $\mathrm{X}$ & \\
Carbendazim+Hidróxido de cobre+OME & $25+38,25+0,5 \%$ & & & $\mathrm{X}$ & & & & \\
\hline 10 Hidróxido de cobre + OME & $38,25+0,25 \%$ & $\mathrm{X}$ & $\mathrm{X}$ & & $\mathrm{X}$ & & & \\
Carbendazim+Hidróxido de cobre+OME & $25+38,25+0,25 \%$ & & & $\mathrm{X}$ & & & \\
\hline 11 Testemunha & & - & & & & & & \\
\hline
\end{tabular}

* $1^{\text {a }}$ aplicação em 29/10/01; $2^{\text {a }}$ aplicação em 26/11/01; $3^{\text {a }}$ aplicação em 26/12/01; $4^{\text {a }}$ aplicação em 24/01/02; $5^{\text {a }}$ aplicação em 31/01/02; $6^{\text {a }}$ aplicação em 25/02/02; $7^{\text {a }}$ aplicação em 04/03/02.

** OME = óleo mineral emulsionável. 
Apêndice 2. Tratamentos fungicidas, doses e épocas de aplicação, utilizados no "Experimento II", no controle da mancha preta dos citros em pomar de laranjeira 'Valência', 2001

\begin{tabular}{|l|c|c|c|c|c|c|c|c|c|}
\hline \multicolumn{1}{|c|}{ Tratamentos } & \multicolumn{2}{c|}{ Dose } & \multicolumn{5}{c|}{ Aplicações* } \\
\hline & (g i. a./100L) & 1 & $2^{\mathrm{a}}$ & $3^{\mathrm{a}}$ & $4^{\mathrm{a}}$ & 5 & $6^{\mathrm{a}}$ & $7^{\mathrm{a}}$ & $8^{\mathrm{a}}$ \\
\hline 1 Hidróxido de cobre + OME** & $90+0,25 \%$ & $\mathrm{X}$ & $\mathrm{X}$ & & & & & & \\
Carbendazim+mancozeb+OME & $25+160+0,25 \%$ & & & $\mathrm{X}$ & & $\mathrm{X}$ & & & \\
\hline 2 Hidróxido de cobre + OME & $38,25+0,25 \%$ & $\mathrm{X}$ & & & $\mathrm{X}$ & & & & \\
Piraclostrobin + OME & $3,75+0,25 \%$ & & $\mathrm{X}$ & & & & $\mathrm{X}$ & & \\
\hline 3 Hidróxido de cobre + OME & $90+0,25 \%$ & $\mathrm{X}$ & $\mathrm{X}$ & & & & & & \\
mancozeb + OME & $160+0,25 \%$ & & & $\mathrm{X}$ & & & & & \\
\hline 4 Hidróxido de cobre + OME & $90+0,25 \%$ & $\mathrm{X}$ & $\mathrm{X}$ & & & & & & \\
Carbendazim+mancozeb+OME & $25+160+0,25 \%$ & & & $\mathrm{X}$ & & & $\mathrm{X}$ & & \\
\hline 5 Hidróxido de cobre + OME & $90+0,25 \%$ & $\mathrm{X}$ & $\mathrm{X}$ & & & & & & \\
Carbendazim+Hidróxido de cobre+OME & $25+90+0,25 \%$ & & & $\mathrm{X}$ & & & $\mathrm{X}$ & & \\
\hline 6 Hidróxido de cobre + OME & $90+0,25 \%$ & $\mathrm{X}$ & $\mathrm{X}$ & & & & & & \\
Carbendazim+Hidróxido de cobre+OME & $12,5+90+0,25 \%$ & & & $\mathrm{X}$ & & & $\mathrm{X}$ & & \\
\hline 7 Hidróxido de cobre + OME & $90+0,25 \%$ & $\mathrm{X}$ & $\mathrm{X}$ & $\mathrm{X}$ & & $\mathrm{X}$ & & $\mathrm{X}$ & \\
\hline 8 Hidróxido de cobre + OME & $38,25+0,25 \%$ & $\mathrm{X}$ & & & $\mathrm{X}$ & & & & \\
Trifloxystrobin + OME & $3,75+0,25 \%$ & & $\mathrm{X}$ & & & & $\mathrm{X}$ & & \\
\hline 9 Hidróxido de cobre + OME & $90+0,25 \%$ & $\mathrm{X}$ & & & & & & \\
Carbendazim + mancozeb +OME & $12,5+80+0,25 \%$ & & $\mathrm{X}$ & $\mathrm{X}$ & & & $\mathrm{X}$ & & \\
\hline 10 Hidróxido de cobre + OME & $90+0,25 \%$ & $\mathrm{X}$ & & & $\mathrm{X}$ & & & & \\
Carbendazim + OME & $25+0,25 \%$ & & $\mathrm{X}$ & & & & $\mathrm{X}$ & & \\
\hline 11 Hidróxido de cobre + OME & $90+0,25 \%$ & $\mathrm{X}$ & $\mathrm{X}$ & $\mathrm{X}$ & & $\mathrm{X}$ & & $\mathrm{X}$ & $\mathrm{X}$ \\
\hline 12 Hidróxido de cobre + OME & $90+0,25 \%$ & $\mathrm{X}$ & $\mathrm{X}$ & $\mathrm{X}$ & & $\mathrm{X}$ & & & \\
\hline 13 Hidróxido de cobre + OME & $38,25+0,25 \%$ & $\mathrm{X}$ & $\mathrm{X}$ & $\mathrm{X}$ & & $\mathrm{X}$ & & $\mathrm{X}$ & $\mathrm{X}$ \\
\hline 14 Hidróxido de cobre + OME & $38,2+0,25 \%$ & $\mathrm{X}$ & $\mathrm{X}$ & & & & & & \\
Carbendazim+Hidróxido de cobre+OME & $12,5+38,2+0,25 \%$ & & & $\mathrm{X}$ & & & $\mathrm{X}$ & & \\
\hline 15 testemunha & & & & & & & & \\
\hline & & & & & \\
\hline
\end{tabular}

* $1^{a}$ aplicação em 23/10/01; $2^{a}$ aplicação em 20/11/01; $3^{\mathrm{a}}$ aplicação em 18/12/01; $4^{\mathrm{a}}$ aplicação em 02/01/02; $5^{\text {a }}$ aplicação em 15/01/02; 6 aplicação em 30/01/02; 7 aplicação em 13/02/02; $8^{\mathrm{a}}$ aplicação em 12/03/02. ** OME = óleo mineral emulsionável. 